\title{
Chemical evolution of
} metamorphic fluids in the Central Alps, Switzerland: Insight from LAICPMS analysis of fluid inclusions

\section{Journal Article}

Author(s):

Rauchenstein-Martinek, Klara; Wagner, Thomas; Wälle, Markus; Heinrich, Christoph A. (1); Arlt, Thilo

Publication date:

2016-12

Permanent link:

https://doi.org/10.3929/ethz-b-000120718

Rights / license:

In Copyright - Non-Commercial Use Permitted

Originally published in:

Geofluids 16(5), https://doi.org/10.1111/gfl.12194 


\title{
Chemical evolution of metamorphic fluids in the Central Alps, Switzerland: insight from LA-ICPMS analysis of fluid inclusions
}

\author{
K. RAUCHENSTEIN-MARTINEK ${ }^{1}$, T. WAGNER ${ }^{2}$, M. WÄLLE ${ }^{1}$, C. A. HEINRICH ${ }^{1}$ AND \\ T. ARLT ${ }^{3}$ \\ ${ }^{I}$ Department of Earth Sciences, Institute of Geochemistry and Petrology, ETH Zurich, Zurich, Switzerland; ${ }^{2}$ Division of \\ Geology and Geochemistry, Department of Geosciences and Geography, University of Helsinki, Helsinki, Finland; ${ }^{3}$ Lengnau, \\ Switzerland
}

\begin{abstract}
The chemical evolution of fluids in Alpine fissure veins (open cavities with large free-standing crystals) has been studied by combination of fluid inclusion petrography, microthermometry, LA-ICPMS microanalysis, and thermodynamic modeling. The quartz vein systems cover a metamorphic cross section through the Central Alps (Switzerland), ranging from subgreenschist- to amphibolite-facies conditions. Fluid compositions change from aqueous inclusions in subgreenschist- and greenschist-facies rocks to aqueous-carbonic inclusions in amphibolite-facies rocks. The fluid composition is constant for each vein, across several fluid inclusion generations that record the growth history of the quartz crystals. Chemical solute geothermometry, fluid inclusion isochores, and constraints from fluid-mineral equilibria modeling were used to reconstruct the pressure-temperature conditions of the Alpine fissure veins and to compare them with the metamorphic path of their host rocks. The data demonstrate that fluids in the Aar massif were trapped close to the metamorphic peak whereas the fluids in the Penninic nappes record early cooling, consistent with retrograde alteration. The good agreement between the fluid-mineral equilibria modeling and observed fluid compositions and host-rock mineralogy suggests that the fluid inclusions were entrapped under rock-buffered conditions. The molar $\mathrm{Cl} / \mathrm{Br}$ ratios of the fluid inclusions are below the seawater value and would require unrealistically high degrees of evaporation and subsequent dilution if they were derived from seawater. The halogen data may thus be better explained by interaction between metamorphic fluids and organic matter or graphite in metasedimentary rocks. The volatile content $\left(\mathrm{CO}_{2}\right.$, sulfur $)$ in the fluid inclusions increases systematically as function of the metamorphic grade, suggesting that the fluids have been produced by prograde devolatilization reactions. Only the fluids in the highest grade rocks were partly modified by retrograde fluid-rock interactions, and all major element compositions reflect equilibration with the local host rocks during the earliest stages of postmetamorphic uplift.
\end{abstract}

Key words: Alps, elemental concentrations, fluid inclusions, fluid sources, halogen ratios, LA-ICPMS analysis, metamorphic fluids

Received 17 March 2016; accepted 10 August 2016

Corresponding author: Thomas Wagner, Division of Geology and Geochemistry, Department of Geosciences and Geography, University of Helsinki, P.O. Box 64 (Gustaf Hällströmin katu 2a), FI-00014 Helsinki, Finland.

Email: thomas.wagner@helsinki.fi. Tel: +358294150835.

Geofluids (2016) 16, 877-908

\section{INTRODUCTION}

Metamorphic fluids play an important role in the structural and chemical evolution of accretionary and collisional orogenic belts (Bickle \& Mckenzie 1987; Connolly \& Thompson 1989; Ferry \& Dipple 1991; Ferry 1994), and they are a key ingredient in hydrothermal systems that form orogenic gold deposits (Ridley 1993; Groves et al. 2003; Goldfarb \& Groves 2015). Metamorphic fluids are derived from prograde metamorphic devolatilization processes as volatile-bearing mineral assemblages become unstable (Norris \& Henley 1976; Fyfe et al. 1987; Oliver 1996; Phillips \& Powell 2010; Tomkins 2010), and they facilitate transport of mass from deeper to shallower parts 
of the crust (Bickle \& Mckenzie 1987; Connolly \& Thompson 1989; Ferry \& Dipple 1991; Ridley 1993; Ferry 1994). Advective fluid flow during late stages of orogenic cycles (related to the exhumation and uplift) is important for the rehydration and retrogression of rocks that were previously metamorphosed at higher P-T conditions (Baumgartner \& Ferry 1991; Cartwright \& Buick 2000; Boiron et al. 2003; Yardley 2013). Fluid systems in orogenic belts may also experience deep ingression of meteoric water down to several kilometers depth, arguably even into the lower crust (Wickham \& Taylor 1985; Templeton et al. 1999; Boiron et al. 2003; Menzies et al. 2014).

Evidences for fluid flow during regional metamorphism are quartz vein arrays in upper crustal rocks (Yardley 1983; Mullis et al. 1994; Cartwright \& Buick 2000; Oliver \& Bons 2001) and abundant fluid inclusions in metamorphic veins and their host rocks (Poty et al. 1974; Mullis 1975, 1987, 1988, 1996; Frey et al. 1980; Mullis et al. 1994; Agard et al. 2000; Touret 2001; Tarantola et al. 2007). Advances in microanalytical techniques such as Raman spectroscopy (Dubessy et al. 1989; Burke 2001; Frezzotti et al. 2012) and laser-ablation inductively coupled plasma mass spectrometry (LA-ICPMS) (Günther et al. 1997, 1998; Heinrich et al. 2003; Allan et al. 2005; Guillong \& Heinrich 2007; Stoffell et al. 2008) now permit complete analysis of the chemical composition of individual fluid inclusions, including the volatile content and the concentrations of dissolved rock-forming elements, ore metals, sulfur and halogens (Seo et al. 2011). Multi-element analysis of fluid inclusions with LA-ICPMS has been widely applied to hydrothermal ore deposits (Audétat et al. 2000; Heijlen et al. 2008; Stoffell et al. 2008; Fusswinkel et al. 2013), but only few studies have addressed the composition of fluids in regionally metamorphosed terrains (Thébaud et al. 2006; Marsala et al. 2013; Miron et al. 2013).

This study reports the results of a fluid inclusion study of quartz fissure veins along a metamorphic cross section through the Central Alps (Switzerland). The veins are hosted by compositionally variable metamorphic rocks ranging from subgreenschist- to amphibolite-facies conditions (Fig. 1). The Central Alps are a geologically young, well-preserved orogenic belt whose geological, tectonic and metamorphic framework is well understood (Trümpy 1960; Trommsdorff 1966; Frisch 1979; Mullis et al. 1994; Frey \& Ferreiro Mählmann 1999; Berger et al. 2011). The Alpine fissure veins crosscut the last peak metamorphic foliation, but show a remarkable correspondence between vein mineralogy and host-rock composition. For our study, we documented the relative time sequence of vein mineral precipitation, but essentially selected simple fissure veins showing one stage of opening and a single generation of well-developed quartz crystals directly growing from the vein wall. We avoided complex veins containing multiple quartz generations as described in Mullis et al. (1994), such as scepter or needle-shaped overgrowths whose stable isotope composition indicates late incursion of meteoric water (Mullis et al. 2001). With this sampling strategy, we can directly link the fluid inclusion results to the principal stage of vein formation and the structural framework. Our study combines fluid inclusion petrography with micothermometry and LA-ICPMS microanalysis, and we report a detailed multi-element dataset of the composition of fluid inclusion assemblages, including major rock-forming elements, ore metals, sulfur, and halogens $(\mathrm{Cl} / \mathrm{Br}$ ratios $)$. The fluid inclusion data are used to evaluate the changes in fluid composition as function of increasing metamorphic grade and to reconstruct the pressure-temperature conditions of vein formation (combining solute geothermometry with fluid inclusion isochores) relative to the peak metamorphic conditions. The analytical data are compared to the results of fluid-mineral equilibria modeling and used to constrain the processes of vein formation within the continuum between fluid- and rock-buffered environments. Finally, the concentration data for fluid-volatile elements such as halogens, boron, and sulfur are used to evaluate potential fluid sources.

\section{REGIONAL GEOLOGICAL SETTING}

Collision between the European and Adriatic continental plates resulted in long-lasting tectonic convergence in the Alpine orogenic belt (Trümpy 1960; Frisch 1979; Tricart 1984; Schmid et al. 1996; Handy et al. 2010) with several metamorphic stages recognized in different parts of the Central Alps (Fig. 1). The basement of the European margin is exposed in the external massifs, including the Aar and Gotthard massifs, which experienced a pre-Alpine history of granitoid magmatism and high-grade metamorphism during several Paleozoic orogeneses. The southern Alps represent the Adriatic microplate, parts of which were overthrust as Austroalpine Nappes over much of the Penninic domain and the southern margin of the European continent (Hurford 1986; Hunziker et al. 1989; Vialon 1990; Hsü 1991; Mullis et al. 1994; Schmid et al. 1996; Pfiffner et al. 2000; Wiederkehr et al. 2009). The Penninic domain consists of a complex nappe stack of continental basement slices, former oceanic crust (ophiolites), and accrectionary wedge metasediments (Bündnerschiefer). Some units of the Penninic nappe stack experienced Eocene to Early Oligocene subduction metamorphism ranging from blueschist to eclogite facies (notably the Adula Nappe between Vals and Locarno; Heinrich 1986; Oberhänsli et al. 1995), prior to the establishment of the consistently north-vergent nappe stack (Schmid et al. 1996; Pfiffner et al. 2000; Wiederkehr et al. 2009). Collision and crustal thickening led to Barrovian-style regional 
Fig. 1. Map of the Central Alps showing essential geological features (major tectonostratigraphic units, metamorphic isograds) and the location of the sampled Alpine fissure veins. The collisional nappe complexes of the Penninic domain (gray shading) are located between the European continent (white) and the partly overthrusted African or Adriatic plate (stippled). Dasheddotted lines indicate the main mineral isograds (pyrophyllite-in, stilpnomelane-out, staurolite-in, and diopside calcite-in). Adopted from Frey \& Ferreiro Mählmann (1999). Redrawn and modified from RauchensteinMartinek et al. (2014).

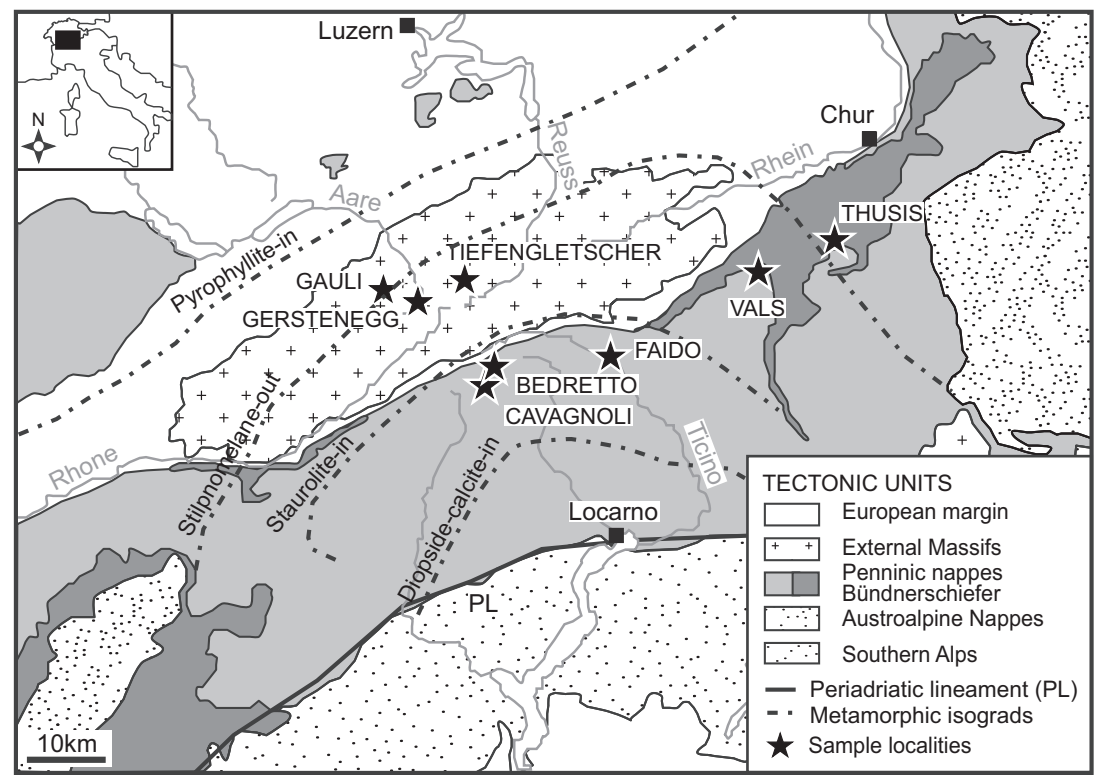

metamorphism of Oligocene to Miocene age, whose isograds cross all nappe boundaries and are domed up in the asymmetric Lepontine metamorphic dome (Fig. 1; Niggli \& Niggli 1965; Trommsdorff 1966; Niggli 1970; Wenk 1970; Frey et al. 1980; Todd \& Engi 1997; Bousquet et al. 1998; Frey \& Ferreiro Mählmann 1999; Wiederkehr et al. 2009). Upper amphibolite-facies units with partial anatexis were exhumed along its southern flank and highest temperature isograds are truncated by the Insubric Line as part of the Periadriatic Lineament south of Locarno (Berger et al. 2009; Rubatto et al. 2009), whereas peak metamorphic grade decreases more gradually northward through the external massifs as a result of the asymmetric uplift of the metamorphic dome during Miocene times (Schlunegger \& Willett 1999; Janots et al. 2009; Berger et al. 2011).

The Alpine fissure veins formed when their metamorphic host rocks were exhumed and crossed the ductile-brittle transition. This resulted in the opening of fractures, and fluids from the local host rock or from deeper parts of the crust were drained into the veins (Burkhard \& Kerrich 1988; Marquer \& Burkhard 1992; Mullis et al. 1994; Mullis 1996; Tarantola et al. 2007, 2009). The age of the Alpine fissure veins is constrained by geochronological data that include older $\mathrm{K}$-Ar dates of adularia and white mica (Purdy \& Stalder 1973) and more recent U-Pb and U-Th$\mathrm{Pb}$ ages of accessory minerals (Sharp et al. 2005; Janots et al. 2012). The K-Ar dates point to vein formation during the broad time interval between 16 and $9 \mathrm{Ma}$ in the Aar and Gotthard massifs in the Central Alps (Purdy \& Stalder 1973), but are subject to uncertain degrees of resetting and/or excess argon. U-Pb dating of titanite from the Gotthard massif yielded an age of 15.2 Ma
(Sharp et al. 2005), and recent U-Th-Pb dating of monazite demonstrated two distinct times of 15.5-14.7 Ma and 13.8-13.6 Ma (Janots et al. 2012), but both are paragenetically late mineral growths relative to the large quartz crystals studied here.

The Alpine fissure veins sampled for this study (Fig. 1, Table 1) are located on a metamorphic cross section through the Lepontine dome of the Central Alps, from the Aar massif in greenschist-facies overprinted basement rocks to the Penninic nappes in amphibolite-facies gneisses and metasedimentary rocks. The central part of the Lepontine dome experienced amphibolite-facies metamorphism at about 35-30 Ma (Trommsdorff 1966; Grujic \& Mancktelow 1996). The core set of sampled fissure veins are hosted by similar quartz-feldspar-mica-bearing lithologies (metagranites or semipelitic schists and gneisses; Table 1), including Gauli (chlorite-mica schist), Gerstenegg (metagranodiorite), Tiefengletscher (metagranite), Cavagnoli (mica schist), and Faido muscovite-biotite gneiss) (Fig. 1). The Gerstenegg fissure vein is exposed in an underground tunnel of the Grimsel power plant and is a protected geoheritage site (Stalder 1986). The core sample suite was complemented by additional fissure veins that are exposed in more diverse host rock lithologies, including Thusis (carbonaceous calc schist), Vals (mafic mica schist), and Bedretto (calc schist).

\section{GEOLOGY AND MINERALOGY OF SAMPLING LOCALITIES}

The Alpine fissure veins are late-tectonic mineral veins that are not completely filled, but they contain open fissures and cavities in their central part that host euhedral crystal 


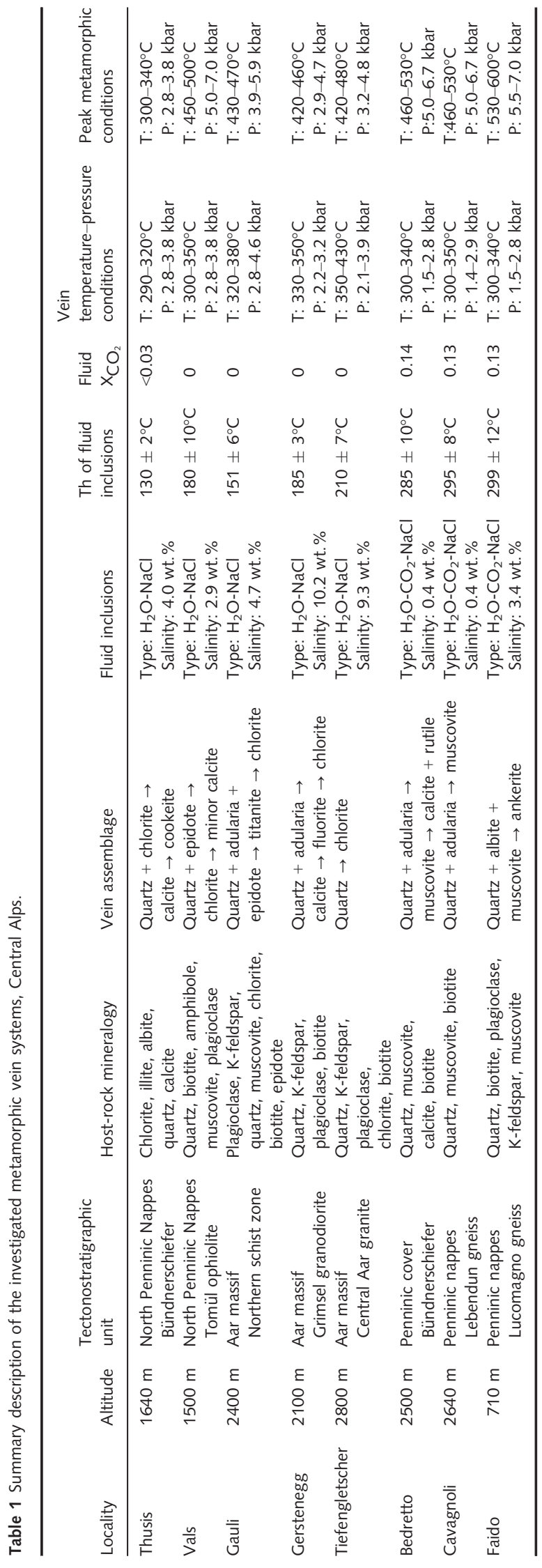


assemblages. The vein mineral assemblages closely reflect the host rock composition, with significant mineralogical differences between metapelites, metagranites, and metabasic rocks (Stalder et al. 1973; Mullis 1975, 1987, 1988; Mullis et al. 1994). Metasomatic alteration zones surrounding the veins are of limited extent, usually comparable to vein volume or smaller, and characterized by depletion in components that are found as major vein filling (note that the terms alteration and metasomatism are used interchangeably in this paper; Yardley 2013). The veins can reach sizes from few centimeters to several meters in thickness and commonly have characteristic sigmoidal shapes (Fig. 2). In the Aar and Gotthard massifs, the Alpine fissure veins are oriented more or less horizontally, crosscutting the steep local foliation dominated by preAlpine metamorphism, whereas in the Penninic nappes, they are mostly subvertical (Demartin et al. 1994;
Hofmann \& Knill 1996; Frey \& Ferreiro Mählmann 1999; Weisenberger \& Bucher 2010). Regardless of the structural style and host-rock lithologies, all fissure veins have characteristic textural features, which include a narrow (centimeter- to decimeter-sized) alteration selvage adjacent to the vein wall-rock contact grading into fresh wall rock, a zone of anhedral, massive quartz grown onto the vein wall-rock contact, and euhedral crystal assemblages, which overgrow the massive quartz. The massive quartz may completely fill the fissure veins at their terminations. Frequently, finegrained vermicular chlorite has precipitated on top of the euhedral crystals.

\section{Thusis}

The samples come from a 1-by-3-m-sized fissure vein above Thusis, which has already been described and
Fig. 2. Field and hand-specimen relationships of Alpine fissure veins. (A) Simplified cross section through the Gerstenegg fissure vein. The upper termination of the vein is filled with massive quartz, whereas the lower termination contains mostly vermicular chlorite, epidote, and adularia. The euhedral quartz crystals are mostly located in the central part of the vein. The upper part of the vein hosts one large calcite crystal overgrown by a late generation of bladed calcite. (B) Close-up view of the large calcite crystal of the Gerstenegg vein. Note that all minerals below the stippled line are covered with fine-grained vermicular chlorite, whereas minerals above the line are not chlorite covered. The late-stage bladed calcite crystals emerge from the stippled line, interpreted as an internal liquid - vapor 'water table' at a late stage in the mineralogical evolution of the vein. (C) Set of flat-lying quartz-chlorite veinlets with one larger fissure vein (bottom) hosting euhedral crystal assemblages; Gauli. (D) Alteration halo of muscovite + albite + adularia + siderite surrounding fissure vein hosted in muscovitebiotite gneiss, showing porous structure from which all quartz was leached out; Faido. The vein contains euhedral quartz and muscovite crystals. (E) Fissure vein assemblage composed of quartz, muscovite, and two generations of adularia (Ad1 and Ad2); Bedretto. Muscovite has formed largely coeval with the younger adularia generation. Mineral abbreviations: Qz, quartz; Chl, chlorite; $\mathrm{Cc}$, calcite; $\mathrm{Fl}$, fluorite; $\mathrm{Mu}$, muscovite; Sid, siderite; Ad, adularia.
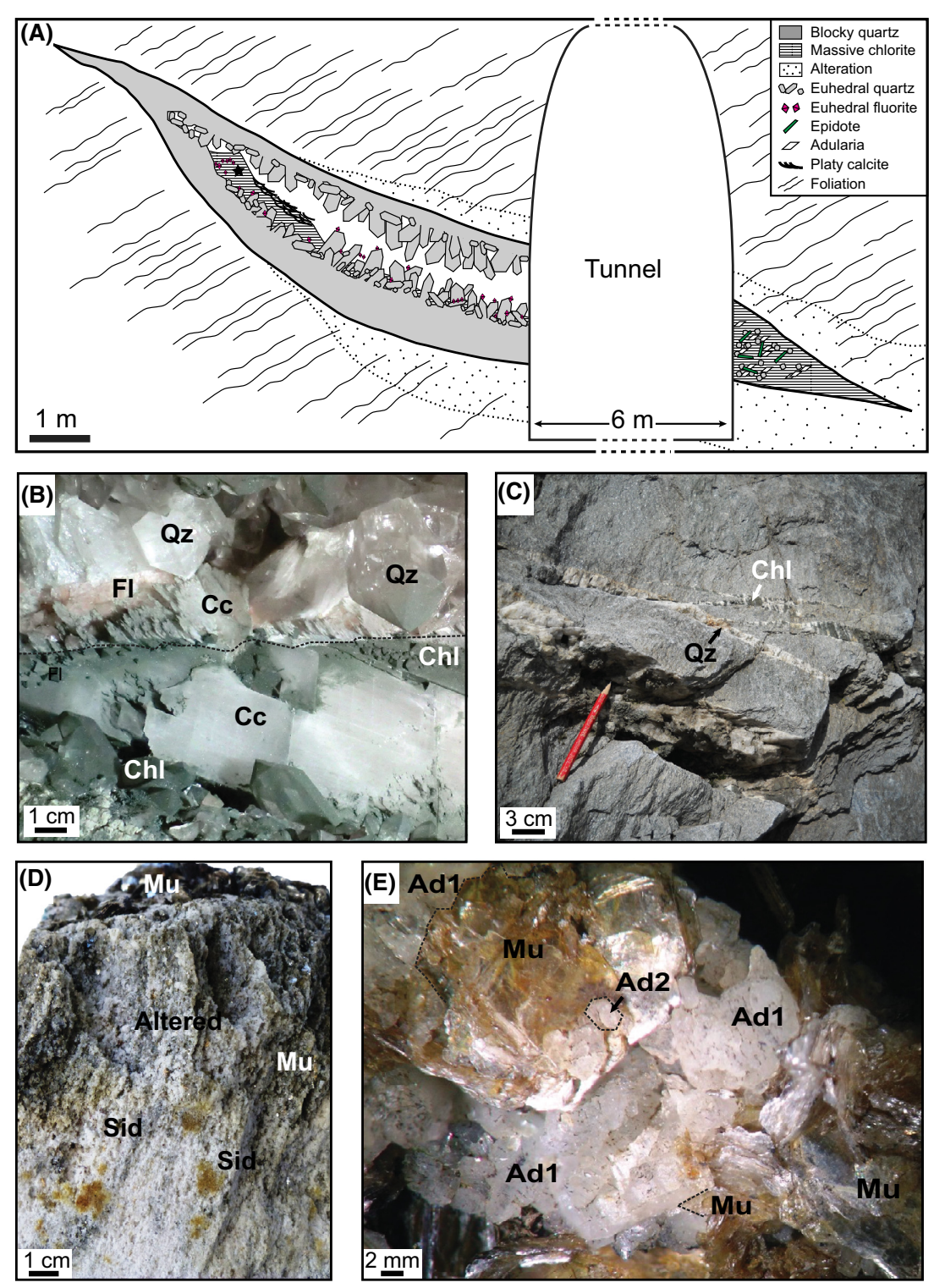
analyzed by Miron et al. (2013). The metapelitic Bündnerschiefer host rocks are rich in carbonates, organic matter, and quartz. The vein minerals are elongated and comprise blocky quartz crystals overgrowing pale green chlorite, and calcite with minor cookeite in the center of the open cavity.

\section{Vals}

The Vals fissure vein samples are situated in the Tomül nappes of the Misox ophiolite zone. The host rocks are mafic schists composed of actinolite, clinozoisite, albite, minor quartz, chlorite, and accessory titanite. The amphiboles are often replaced by chlorite at their rims. The few mm-thick alteration zone surrounding the fissure veins is only visible around the lower part of the veins and is characterized by an increase in chlorite and minor actinolite and tremolite. Within the open cavities of the more horizontally oriented vein, euhedral quartz crystals, epidote, chlorite and calcite are present. The quartz crystals growing on the footwall of the fissure vein are covered by fine-grained chlorite, and they also contain chlorite inclusions, whereas the quartz grown on the hanging wall is chlorite free. The carbonate minerals only appear as a late phase on the chlorite covered quartz crystals.

\section{Gauli}

The host rocks of the fissure veins in the Gauli region are composed of quartz, plagioclase, K-feldspar, muscovite, calcite, biotite, chlorite, and the accessory minerals titanite and apatite. The large porphyroclasts of quartz, K-feldspar, and plagioclase are deformed and elongated parallel to the foliation, which is defined by biotite that is partly retrograded to chlorite and muscovite. This structure suggests that the host rocks are likely metamorphosed arkosic sedimentary rocks. Fissure veins in the Gauli region include abundant quartz-chlorite veinlets, whereas larger open fissure veins with euhedral crystal assemblages are found in a narrow zone close to the Gauli glacier. The larger open fissure veins are typically associated with several smaller veinlets mostly filled with massive quartz. Together, they form sets of veins that are arranged en echelon. The studied samples come from two parallel open fissure veins located just next to the current margin of the Gauli glacier (about $3 \mathrm{~m}$ distance from each other). They are up to $1 \mathrm{~m}$ in thickness and $3-5 \mathrm{~m}$ in length. The veins are surrounded by a 2 - to $3-\mathrm{cm}$-thick leaching zone composed of feldspars and muscovite and minor quartz and chlorite. The vein wall is covered with blocky quartz, which is overgrown by euhedral open space-filling minerals. Albite crystals are overgrown by quartz and adularia, followed by a chlorite cover in the lower part of the fissure vein. In this part, the chlorite covered quartz crystals contain also cm-sized titanite and minor epidote crystals on top.

\section{Gerstenegg}

The Gerstenegg fissure vein is situated in the Grimsel granodiorite that is mainly composed of plagioclase, $\mathrm{K}$-feldspar, amphibole, biotite, muscovite, and chlorite. In the vicinity of the fissure vein, the biotite is altered to muscovite and chlorite and the feldspars are partly replaced by sericite. The main Gerstenegg fissure vein is about $9 \mathrm{~m}$ long and $5.6 \mathrm{~m}$ thick and preserved as a publicly accessible, protected geological site inside the KWO power plant (Stalder 1986). It is part of a set of essentially parallel fissure veins, which crosscut the main foliation of the metagranodiorite host rock at high angles. Our samples come from the middle part and the lower and upper terminations of the main fissure vein (Fig. 2A). The vein is surrounded by an alteration selvage of several centimeters thickness that is well developed in the central and lower part of the vein, but largely absent in the upper part. The alteration close to the lower termination of the vein (where the vein is filled by chlorite, adularia, and epidote) is manifested by a porous and bleached host rock that clearly has lost most of its quartz without obliteration of the metagranitoid texture.

The upper termination of the fissure vein is filled with massive quartz, which continuously grades into the open cavity as euhedral quartz crystals in places where the vein is thicker than about $30 \mathrm{~cm}$. The most abundant mineral in the open fissure is quartz which is present as euhedral crystals with sizes of few $\mathrm{cm}$ up to $20 \mathrm{~cm}$. A large blocky calcite crystal is present close to the upper termination of the vein. This blocky calcite shows a prominent subhorizontal line along the surface (Fig. 2B). From this line, a younger generation of platy calcite crystals emerges and the part below the line is covered by vermicular chlorite, whereas the part above the line does not have a chlorite overgrowth. This chlorite also grows on top of abundant pink fluorite crystals of $0.5-1.0 \mathrm{~cm}$ size that have grown on top of the quartz and the calcite. The center of the Gerstenegg vein contains an accumulation of sandy chlorite with some platy calcite crystals (Fig. 2A). Sandy chlorite, apparently sedimented in the cavity as late-precipitating mineral, also occurs in the lower part of the fissure near the visitor window in the main tunnel (Fig. 2A). This chlorite completely fills the lowest tip of the vein on the other side of the tunnel, where none of the other minerals occur. The sulfide minerals pyrite and galena are present in trace amounts in the middle part of the fissure vein in a narrow vein that branches off from the main vein (Stalder 1986). In the lower part of the fissure vein that is surrounded by an extensive alteration and leaching halo, the rock-forming minerals of the Grimsel granodiorite epidote, titanite, and apatite have crystallized inside the vein, together with 
abundant adularia crystals. Fluorite, galena, and milarite were exclusively found inside the cavity (Stalder 1964, 1986; Mercolli et al. 1984).

\section{Tiefengletscher}

In the proximity of the Tiefengletscher, Peter Indergand Sr. discovered a quartz crystal group in 1946, which represents one of the most spectacular groups of smoky quartz ever found in the Alps and is now hosted by the focusTerra museum at ETH Zurich. Our studied quartz samples originate from the same fissure as the Indergand specimen. The host rock is the central Aar granite, which is composed of plagioclase, K-feldspar, biotite, muscovite, and chlorite. The fissure vein belongs to a set of several parallel veins that are oriented horizontally and crosscut the hostrock foliation at a high angle. The vein is about $8 \mathrm{~m}$ in length and opens up in the center to an open cavity of 70 to $120 \mathrm{~cm}$ in width. The dark smoky quartz crystals reach sizes up to $45 \mathrm{~cm}$ and are associated with calcite, chlorite, and apatite (Indergand-Helfenstein 2005).

\section{Bedretto}

The fissure veins in the Bedretto valley are hosted by Bündnerschiefer metasedimentary rocks of amphibolitefacies metamorphic grade (Wiederkehr et al. 2009). They are composed of dominantly quartz, muscovite, carbonates, amphibole, and altered biotite, with staurolite, garnet, and biotite in metapelitic rocks nearby. The samples originate from a set of almost vertical, typically $\mathrm{cm}$-wide fissure veins. The investigated area contains a large number of individual veins, but only few of them are thicker than $10 \mathrm{~cm}$ and host open cavities. They are bordered by a selvage of altered host rocks, and both the alteration zones and the veins contain relicts of carbonate minerals that are largely weathered. The vein mineral assemblage comprises quartz and muscovite, and minor amounts of calcite, adularia, and rutile. Following a thin marginal zone of anhedral quartz that is directly grown onto the wall rock, euhedral crystals form the central part of the vein filling. The euhedral quartz is intergrown with adularia and muscovite crystals and the textural relationships suggest essentially synchronous growth of all three minerals (Fig. 2E). Adularia is present as two distinct generations, with earlier large white adularia crystals overgrown by later smaller crystals of brownish adularia. Sometimes, the lower parts of the veins are completely filled by up to 10 - $\mathrm{cm}$-sized adularia crystals, while the upper parts contain mostly quartz.

\section{Cavagnoli}

The fissure veins in the Cavagnoli area are hosted by gneisses that have a metasedimentary protolith. They consist of plagioclase, angular quartz, K-feldspar (partly altered to sericite), green hornblende, biotite, muscovite, and titanite. The fissure veins have a subvertical orientation and occur in a structural corridor that extends from the Bedretto valley to the higher mountains south of the Cavagnoli valley. The veins have typical thicknesses of few $\mathrm{cm}$ and most veins are completely filled by quartz. Few veins are up to $50 \mathrm{~cm}$ thick and contain open cavities with euhedral crystals. The mineral assemblage is similar to Bedretto, with an intergrowth of quartz, adularia and muscovite making up most of the vein filling. In addition, rutile crystals have locally grown on top of euhedral quartz crystals.

\section{Faido}

The samples come from a set of fissure veins exposed in an underground exploration tunnel built for the NEAT railway tunnel in the Lucomagno gneiss. The unaltered hostrock gneiss is composed of quartz, biotite, plagioclase, $\mathrm{K}$ feldspar, muscovite, and ankerite. The alteration and leaching zone surrounding the fissure veins contains mainly $\mathrm{K}$ feldspar and plagioclase and only minor quartz. Because the veins are exposed several hundred meters below the surface, the full mineral assemblage including the carbonate phases is preserved. The veins are subvertically oriented and their structure resembles those of the Bedretto and Cavagnoli area. The upper part of the fissure veins is commonly completely filled by massive quartz that is overgrown by euhedral quartz crystals in the central open cavity. The lower part of the veins typically contains larger proportions of muscovite and adularia associated with quartz crystals, and the crystal faces of all three minerals are sometimes covered by vermicular chlorite. Rarely, small crystals of ankerite and calcite have grown on top of quartz crystals and the chlorite. Only the central part of the fissure vein contains abundant muscovite that is associated with quartz and adularia.

\section{ANALYTICAL METHODS}

\section{Whole-rock geochemistry}

Whole-rock samples (including hydrothermally altered wall rocks of fissure veins and fresh host rocks sampled at few meters distance from the veins) were analyzed for the concentrations of major and minor elements, inorganic and organic carbon, sulfur, and ferrous and total iron. Major and minor element concentrations were determined by wavelength-dispersive X-ray fluorescence spectroscopy (XRF) with a PANalytical Axios instrument, using glass beads prepared from dry rock powder and lithium tetraborate. The FeO content was determined at the University of Lausanne by wet chemistry and colorimetric methods (Wilson 1960; Johnson \& Maxwell 1981; Wülser et al. 2011). 
The carbon content was determined with a UIC Inc. CM 5012 carbon analyzer. The carbon in the sample is combusted in a furnace (CM 5200) and then introduced into the coulometer, and this analysis yields the total carbon content. The inorganic carbon content (i.e., carbon dioxide) is determined separately by acid digestion (CM 5130). The organic carbon content is then calculated as the difference between total and inorganic carbon. The water content was not directly determined, but calculated from the loss on ignition, the carbon and sulfur content, and the ferrous/ferric iron ratio.

\section{Fluid inclusion microthermometry}

Fluid inclusion assemblages (FIA), that is groups of fluid inclusions that were trapped coevally on constrained growth zones or healed fractures (Goldstein \& Reynolds 1994; Touret 2001), were established by detailed fluid inclusion petrography. All fluid inclusion data are reported as assemblage averages with their standard deviations. Fluid inclusion microthermometry was performed using a Linkam THMSG-600 freezing-heating stage, attached to a Leitz optical microscope. The calibration was performed on synthetic fluid inclusions of pure $\mathrm{H}_{2} \mathrm{O}$ (final ice-melting temperature: $0.0^{\circ} \mathrm{C}$, homogenization temperature: $374.0^{\circ}$ ) and $\mathrm{CO}_{2}$ (final $\mathrm{CO}_{2}$ ice-melting temperature: $-56.6^{\circ} \mathrm{C}$ ) from SYNFLINC. The aqueous two-phase inclusions were cooled to $-100^{\circ} \mathrm{C}$, then heated at a rate of $100^{\circ} \mathrm{C} \mathrm{min}^{-1}$ to $-20^{\circ} \mathrm{C}$, heated with $10^{\circ} \mathrm{C} \mathrm{min}^{-1}$ until $-10^{\circ} \mathrm{C}$, and then with $1^{\circ} \mathrm{C} \mathrm{min}{ }^{-1}$ and $0.5^{\circ} \mathrm{C} \mathrm{min}^{-1}$ close to the final ice-melting temperature $\left(\mathrm{Tm}_{\mathrm{ice}}\right)$. Total homogenization temperatures $\left(\mathrm{Th}_{\mathrm{tot}}\right)$ were measured by heating the fluid inclusions at a rate of $100^{\circ} \mathrm{C} \mathrm{min}{ }^{-1}$ up to $150^{\circ} \mathrm{C}$ and then with $1{ }^{\circ} \mathrm{C} \mathrm{min}-1$ close to the homogenization temperature. The aqueouscarbonic three-phase inclusions were cooled to $-100^{\circ} \mathrm{C}$ and then heated with $20^{\circ} \mathrm{C} \mathrm{min}{ }^{-1}$ to $-60^{\circ} \mathrm{C}$ and $1^{\circ} \mathrm{C} \min ^{-1}$ close to the final $\mathrm{CO}_{2}$ ice-melting temperature $\left(\mathrm{Tm}_{\mathrm{CO}_{2}}\right)$. Subsequently, the fluid inclusions were heated at a rate of $50^{\circ} \mathrm{C} \mathrm{min}{ }^{-1}$ to $-10^{\circ} \mathrm{C}$ and with $0.5^{\circ} \mathrm{C} \mathrm{min}^{-1}$ close to the clathrate melting temperature $\left(\mathrm{Tm}_{\mathrm{Cla}}\right)$. Partial homogenization temperatures of the $\mathrm{CO}_{2}$ phase $\left(\mathrm{Th}_{\mathrm{CO}_{2}}\right)$ were determined by warming the fluid inclusions from room temperature with $5^{\circ} \mathrm{C} \mathrm{min}{ }^{-1}$ and then with $1^{\circ} \mathrm{C} \mathrm{min}^{-1}$ close to the homogenization temperature. Total homogenization temperatures were only determined for some inclusions from a given FIA and were typically measured after the elemental composition of larger fluid inclusions had been analyzed by LAICPMS. Total homogenization was measured by heating the fluid inclusions with $50^{\circ} \mathrm{C} \mathrm{min} \mathrm{m}^{-1}$ to 200 or $250^{\circ} \mathrm{C}$ and then with $2^{\circ} \mathrm{C} \mathrm{min}^{-1}$ close to the homogenization temperature. The precision of the microthermometric measurements is about $\pm 0.1^{\circ} \mathrm{C}$ for melting temperatures and $\pm 1{ }^{\circ} \mathrm{C}$ for homogenization temperatures, based on replicate measurements of the calibration standards.

Salinities were calculated as wt.\% equivalent (eqv.) $\mathrm{NaCl}$ from the final ice-melting temperature for the aqueous inclusions (Bodnar 1993) and from the $\mathrm{CO}_{2}$ clathrate melting temperature for the aqueous-carbonic inclusions (Diamond 1992). Fluid inclusion densities and isochores were calculated with the FLUIDS software package (Bakker 2003). For aqueous fluid inclusions, the bulk density was calculated from the microthermometric data alone, using the equation for $\mathrm{H}_{2} \mathrm{O}-\mathrm{NaCl}$ of Zhang \& Frantz (1987) as implemented in the FLUIDS program of Bakker (2003). For aqueous-carbonic inclusions, the volume proportions of the $\mathrm{CO}_{2}$ and $\mathrm{H}_{2} \mathrm{O}$ phases had to be estimated. This was performed by heating the inclusions to $40^{\circ} \mathrm{C}$, where both the aqueous and carbonic phases are assumed to be close to the pure end-member composition, the $\mathrm{H}_{2} \mathrm{O}$ phase is nearly incompressible and the pressure is fixed by the isochore for the one-phase $\mathrm{CO}_{2}$ fluid at $40^{\circ} \mathrm{C}$ (Burrus 1981). The area fractions of the $\mathrm{CO}_{2}$ and $\mathrm{H}_{2} \mathrm{O}$ phases were then estimated graphically, and area fractions were extrapolated to volume fractions to obtain the bulk $\mathrm{CO}_{2} /\left(\mathrm{CO}_{2}+\mathrm{H}_{2} \mathrm{O}\right)$ ratio.

\section{LA-ICPMS microanalysis of fluid inclusions}

Individual fluid inclusions were analyzed using the ETHGeoLas system (193 nm excimer laser) connected to an ICP-quadrupole-MS (Perkin Elmer Elan 6100 DRC) (Günther et al. 1997; Heinrich et al. 2003). To increase the sensitivity for heavier trace elements, $\mathrm{H}_{2}$ was added to the Ar flow with $5 \mathrm{ml} \mathrm{min}{ }^{-1}$ (Guillong \& Heinrich 2007). For controlled complete ablation of the quartz-hosted fluid inclusions, an energy density above $15 \mathrm{~J} \mathrm{~cm}^{-2}$ and a laser pulse frequency of $10 \mathrm{~Hz}$ was used. The optical imaging system permits a rapid widening of the ablation crater from 10 to $120 \mu \mathrm{m}$ at constant laser energy density by adjusting an aperture in the laser beam path. In the fluid inclusions, the following elements were analyzed: $\mathrm{Li}, \mathrm{Na}, \mathrm{K}, \mathrm{Rb}, \mathrm{Cs}$, $\mathrm{Mg}, \mathrm{Ca}, \mathrm{Sr}, \mathrm{Ba}, \mathrm{B}, \mathrm{Al}, \mathrm{Fe}, \mathrm{Mn}, \mathrm{Cu}, \mathrm{Zn}, \mathrm{Pb}, \mathrm{Ag}, \mathrm{As}, \mathrm{Sb}$, $\mathrm{Ti}, \mathrm{S}, \mathrm{Cl}$, and Br. Selected fluid inclusions from the FIA that were analyzed with this multi-element menu were also measured with a reduced menu optimized for analyzing the $\mathrm{Cl} / \mathrm{Br}$ ratio (Seo et al. 2011). This element menu included only $\mathrm{Na}, \mathrm{Rb}, \mathrm{Cl}$, and $\mathrm{Br}$. The $\mathrm{Ca}$ concentration was measured on isotope ${ }^{44} \mathrm{Ca}$, which has about three times higher isotopic abundance than ${ }^{42} \mathrm{Ca}$. Although ${ }^{44} \mathrm{Ca}$ is affected by interference from ${ }^{28} \mathrm{Si}^{16} \mathrm{O}^{+}$produced from ablation of the host quartz, the effect is small and can be corrected for by host background subtraction. NIST-610 was used as standard material for most of the elements except $\mathrm{Cl}$ and $\mathrm{Br}$ where the Sca-17 scapolite standard (Seo et al. 2011) was applied. Element concentrations were quantified using the SILLS software package that 
deconvolves the host mineral and fluid inclusion signal (Guillong et al. 2008). The analyzed element ratios were converted into absolute concentrations using the microthermometrically determined salinity. Because most fluid inclusions contain considerable concentrations of $\mathrm{K}$ and $\mathrm{Ca}$, the common salt correction procedure was used (Heinrich et al. 1992).

Each fluid inclusion signal was screened and only data with clearly visible peaks and intensities above $3 \sigma$ of the background were considered for calculation of element concentrations (Fig. 3). In addition, signals were screened for the presence of accidentally trapped solid phases inside the fluid inclusion, which are typically associated with a large simultaneous increase in a group of elements compared to the fluid inclusion assemblage average (about half to one order of magnitude). The detection limit for each element varied as a function of the size of the fluid inclusions, and some elements could therefore only be quantified in larger inclusions. Some inclusions were analyzed for a smaller subset of elements focused on ore metals and are included here, but were published separately in Rauchenstein-Martinek et al. (2014).

\section{Phase equilibria computation}

Fluid-mineral equilibria modeling in the multicomponent multiphase system $\mathrm{Na}-\mathrm{K}-\mathrm{Ca}-\mathrm{Mg}-\mathrm{Fe}-\mathrm{Si}-\mathrm{Al}-\mathrm{C}-\mathrm{S}-\mathrm{H}-\mathrm{O}-\mathrm{Cl}$ was performed with the GEMS3 Gibbs free energy minimization package (Karpov et al. 1997; Wagner et al. 2012; Kulik et al. 2013). The calculations account for fluid speciation, mineral solubility, and solid solution effects of the main rock-forming minerals and predict fluid composition, $\mathrm{pH}$, and oxidation state as function of pressure and temperature and bulk rock composition. The thermodynamic dataset employed was based on the model used earlier (Dolejs \& Wagner 2008), with additions for aqueous carbon and sulfur species, carbonate and sulfide minerals, and their solid solutions. Data for aqueous species came from the SUPCRT92 dataset and updates (Shock \& Helgeson 1988; Shock et al. 1989, 1997; Johnson et al. 1992; Sverjensky et al. 1997; Tagirov et al. 1997; Tagirov \& Schott 2001), while data for rock-forming minerals came from the Holland-Powell internally consistent dataset (Holland \& Powell 1998; Evans et al. 2010). The activity-composition relationships for rock-forming mineral solid solutions were modeled by ideal, nonideal, symmetric, and asymmetric models (Powell \& Holland 1993, 1999; Holland \& Powell 1996, 1998, 2003; Holland et al. 1998; Coggon \& Holland 2002; Wei et al. 2003; Dale et al. 2005; Evans et al. 2010). Activity coefficients of aqueous species and water solvent were calculated from an extended DebyeHückel model (Helgeson et al. 1981; Walther 1997, 2001). The overall uncertainty of the phase equilibria computation is largely determined by the uncertainty of the thermodynamic data and is estimated as approximately $0.5 \log$ units in the predicted equilibrium
Fig. 3. Representative LA-ICPMS signals for aqueous-carbonic (A, B) and aqueous (C, D) fluid inclusions. The sharp increase in $\mathrm{Si}$ above background indicates the onset of quartz host ablation and the large $\mathrm{Na}$ peak the breaching of the fluid inclusion. The signals for all elements analyzed (of which only $\mathrm{K}, \mathrm{Ba}, \mathrm{Fe}, \mathrm{Mn}, \mathrm{Cu}, \mathrm{Ag}, \mathrm{Au}, \mathrm{As}, \mathrm{Sb}, \mathrm{Al}$, $\mathrm{Ti}$, and/or $\mathrm{Cl}$ are shown) closely follow the shape of the Na signal, reflecting the absence of any daughter or accidentally trapped solids.
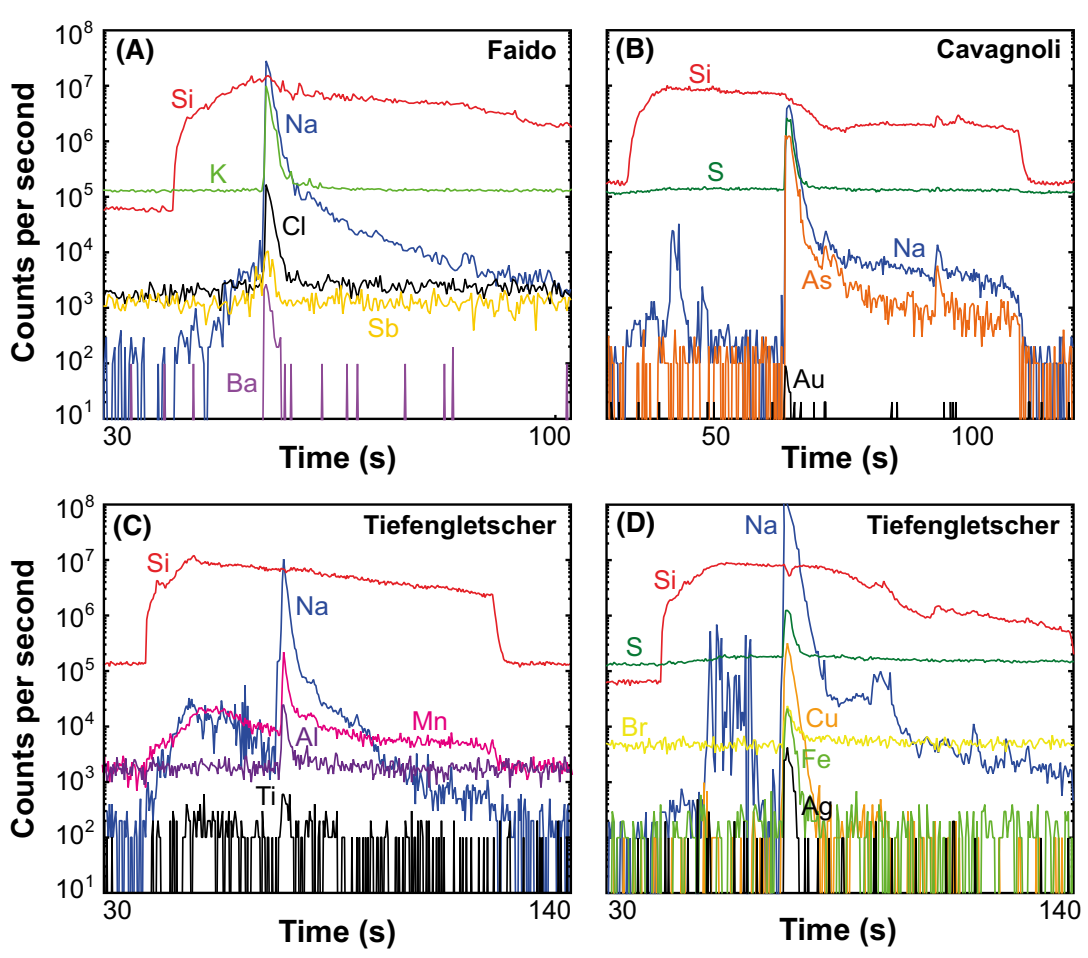
concentrations of dominant aqueous species (Johnson et al. 1992; Sverjensky et al. 1997).

Fluid-mineral equilibria were computed for five Alpine fissure vein systems that cover localities from greenschist to amphibolite facies and different host-rock lithologies (metagranite, gneiss, mica schist, and mafic greenschist). The calculations were run over a large range of temperatures from 200 to $600^{\circ} \mathrm{C}$ and at the estimated vein-forming pressure of $3.0,2.5,3.0,2.0$, and $1.8 \mathrm{kbar}$ for the localities Tiefengletscher, Gerstenegg, Gauli, Faido, and Cavagnoli, respectively. The analyzed whole-rock composition was converted into the model system $\mathrm{SiO}_{2}-\mathrm{Al}_{2} \mathrm{O}_{3}-\mathrm{Fe}_{2} \mathrm{O}_{3}-\mathrm{FeO}-\mathrm{MgO}-\mathrm{CaO}$ $\mathrm{Na}_{2} \mathrm{O}-\mathrm{K}_{2} \mathrm{O}-\mathrm{CO}_{2}-\mathrm{S}-\mathrm{H}_{2} \mathrm{O}$ (Table 2). This simplification was performed by subtracting $\mathrm{TiO}_{2}$ and stoichiometric amounts of $\mathrm{CaO}$ proportional to the amount of $\mathrm{P}_{2} \mathrm{O}_{5}$, accounting for modal rutile and apatite. The recalculated whole-rock composition was then normalized to $1000 \mathrm{~g}$. The input fluid was based on the observed fluid inclusion composition of each locality, but initially simplified to the major salt and volatile components $\mathrm{H}_{2} \mathrm{O}-\mathrm{CO}_{2}-\mathrm{H}_{2} \mathrm{~S}-\mathrm{NaCl}$ (Table 3). Fluid-rock equilibria were calculated at rock-dominated conditions, using a fixed mass-based input fluid/rock ratio of 0.1 , to predict the concentrations of all aqueous species as well as the composition and abundance of minerals at equilibrium. Due to mineral dissolution and precipitation that change as function of temperature and pressure, the calculated output equilibrium fluid/rock ratios vary slightly from the initial input fluid/rock ratio.

\section{FLUID INCLUSION RESULTS}

\section{Inclusion petrography}

Fluid inclusion studies focused on euhedral quartz crystals of 3 to $10 \mathrm{~cm}$ in size. The quartz crystals contain several sequential growth zones, which constrain the relative chronology of different fluid inclusion assemblages in relation to the crystal growth (Figs 4 and 5). The fluid inclusions are typically $10-250 \mu \mathrm{m}$ in size in all investigated samples. We selected fluid inclusion assemblages that contained a sufficient number of inclusions of $50-120 \mu \mathrm{m}$ in size for detailed microthermometry and LA-ICPMS analysis, permitting multi-element LA-ICPMS analysis with good sensitivity and reproducibility for each FIA.

In the Gauli samples, the oldest FIA were found in the anhedral marginal zone of the quartz that lines the vein wall. These fluid inclusions (FI) have typically sizes of 20 to $60 \mu \mathrm{m}$. They occur as numerous pseudosecondary trails, which terminate at grain boundaries (Fig. 4, Type 1; corresponding to assemblages Al to A7 in Table 4 and Data S1). This zone is overgrown by euhedral quartz crystals. They contain numerous pseudosecondary fluid inclusions within their core, adjacent to the anhedral quartz at the base of the crystals. Most of the FI in this part of the crystal are aligned on pseudosecondary trails, whereas few larger FI (up to $200 \mu \mathrm{m}$ ) with irregular shape occur as groups without a clear relation to healed microfractures or growth zones. The fluid inclusion-rich cores of the quartz crystals are overgrown by a highly transparent quartz, which is typically separated from the core by a euhedral growth zone (Type 4 in Fig. 4; corresponding to FIA A8 to Al4 in Table 4 and Data S1). This outer part of the quartz crystals contains mainly trails of secondary FI, which also crosscut the older cores of the crystals. All fluid inclusions in the Gauli samples are aqueous two-phase (LV) inclusions with similar phase proportions.

The samples from Gerstenegg, Tiefengletscher and Vals contain fluid inclusion assemblages with a chronology that is similar to that of the Gauli samples. The crystals contain mainly pseudosecondary FI in an inclusion-rich core and clearer outer growth zones (one or sometimes several ones) that mainly contain secondary FI (Fig. 5). The secondary FI are aligned on well-defined long trails that crosscut the older trails with pseudosecondary FI in the core of the crystals. In the Gerstenegg samples, euhedral fluorite crystals that have grown on top of the quartz crystals contain distinctly later fluid inclusions with smaller bubbles. All fluid inclusions from Gerstenegg, Tiefengletscher, and Vals are aqueous twophase (LV) inclusions.

The quartz crystals in the samples from Bedretto, Cavagnoli and Faido contain a core with abundant FI aligned on many short pseudosecondary trails (Fig. 6). The crystal cores are overgrown by one or several clearer growth zones that contain few short trails with pseudosecondary FI, but otherwise, the crystals host mainly secondary FI on distinct trails that also crosscut the rim and core of the crystals. The relative timing of the pseudosecondary FI in the clearer outer parts of the crystals is difficult to establish. They are younger than the pseudosecondary FI in the crystal cores, but may be older or have the same relative age as the secondary FIA that are aligned on the larger crosscutting trails. All fluid inclusions in the samples from Bedretto, Cavagnoli and Faido are aqueous-carbonic threephase (LLV) inclusions with apparently identical phase proportions.

\section{Microthermometry}

Consistent with previous regional studies (Mullis et al. 1994), the Alpine fissure veins of this study contain two-phase aqueous fluid inclusions of the LV-type in greenschist-facies rocks in the northern part of the study area (Thusis, Vals, Gauli, Gerstengg and Tiefengletscher) 
Table 2 Summary of whole-rock geochemical data, including major and minor elements and volatiles (inorganic and organic carbon, sulfur). Analytical totals were calculated from major element oxides (total iron expressed as ferric iron) and loss on ignition (LOI).

\begin{tabular}{|c|c|c|c|c|c|c|c|c|c|c|}
\hline Sample & $\begin{array}{l}\text { ICM-G-2 } \\
\text { Gauli }\end{array}$ & $\begin{array}{l}\text { ICM-G-3 } \\
\text { Gauli }\end{array}$ & $\begin{array}{l}\text { ICM-G-9 } \\
\text { Gauli }\end{array}$ & $\begin{array}{l}\text { ICM-GE-2 } \\
\text { Gerstenegg }\end{array}$ & $\begin{array}{l}\text { ICM-GE-3 } \\
\text { Gerstenegg }\end{array}$ & $\begin{array}{l}\text { ICM-GE-4 } \\
\text { Gerstenegg }\end{array}$ & $\begin{array}{l}\text { ICM-GE-5 } \\
\text { Gerstenegg }\end{array}$ & $\begin{array}{l}\text { ICM-GE-6 } \\
\text { Gerstenegg }\end{array}$ & $\begin{array}{l}\text { ICM-C-1 } \\
\text { Cavagnoli }\end{array}$ & $\begin{array}{l}\text { ICM-F-2 } \\
\text { Faido }\end{array}$ \\
\hline \multicolumn{11}{|l|}{ Wt. \% } \\
\hline $\mathrm{SiO}_{2}$ & 68.76 & 67.19 & 64.88 & 66.73 & 69.13 & 68.50 & 68.57 & 66.70 & 60.44 & 70.95 \\
\hline $\mathrm{TiO}_{2}$ & 0.45 & 0.66 & 1.37 & 0.66 & 0.63 & 0.57 & 0.70 & 0.59 & 0.66 & 0.38 \\
\hline $\mathrm{Al}_{2} \mathrm{O}_{3}$ & 15.80 & 15.65 & 17.82 & 16.97 & 15.99 & 16.75 & 15.97 & 16.83 & 21.17 & 13.73 \\
\hline $\mathrm{Fe}_{2} \mathrm{O}_{3}$ & 1.12 & 1.35 & 0.92 & 0.95 & & 1.08 & 1.46 & & 2.71 & 1.63 \\
\hline $\mathrm{FeO}$ & 1.78 & 2.70 & 0.46 & 0.07 & & 0.34 & 0.57 & & 0.21 & 0.80 \\
\hline $\mathrm{MnO}$ & 0.04 & 0.05 & 0.02 & 0.02 & 0.02 & 0.03 & 0.04 & 0.06 & 0.02 & 0.04 \\
\hline $\mathrm{MgO}$ & 0.96 & 1.34 & 0.46 & 0.15 & 0.21 & 0.28 & 0.48 & 0.76 & 0.62 & 0.38 \\
\hline $\mathrm{CaO}$ & 1.85 & 1.84 & 2.86 & 2.36 & 2.46 & 2.55 & 2.92 & 2.77 & 0.43 & 1.34 \\
\hline $\mathrm{Na}_{2} \mathrm{O}$ & 3.22 & 3.56 & 5.02 & 6.23 & 5.46 & 5.23 & 4.85 & 5.02 & 4.12 & 4.28 \\
\hline $\mathrm{K}_{2} \mathrm{O}$ & 4.12 & 3.86 & 4.25 & 3.46 & 3.33 & 4.03 & 3.56 & 3.56 & 7.78 & 4.56 \\
\hline $\mathrm{P}_{2} \mathrm{O}_{5}$ & 0.22 & 0.27 & 0.47 & 0.19 & 0.19 & 0.18 & 0.23 & 0.19 & 0.15 & 0.19 \\
\hline $\mathrm{CO}_{2}$ & 1.31 & 2.16 & 0.03 & 0.25 & 0.07 & 0.13 & 0.26 & 0.22 & 0.09 & 0.71 \\
\hline C (org) & 0.10 & 0.37 & 0.26 & 0.00 & 0.03 & 0.00 & 0.02 & 0.01 & 0.27 & 0.01 \\
\hline$S$ & 0.00 & 0.03 & 0.00 & 0.00 & 0.00 & 0.00 & 0.00 & 0.00 & 0.00 & 0.94 \\
\hline LOI & 1.53 & 1.24 & 1.11 & 1.33 & 1.24 & 0.65 & 0.78 & 0.78 & 1.71 & 1.84 \\
\hline Total & 100.04 & 100.00 & 99.69 & 99.12 & 99.86 & 100.23 & 100.20 & 100.06 & 100.03 & 100.21 \\
\hline \multicolumn{11}{|l|}{ ppm } \\
\hline $\mathrm{Rb}$ & 120 & 154 & 129 & 120 & 124 & 139 & 143 & 130 & 191 & 124 \\
\hline $\mathrm{Ba}$ & 1170 & 1140 & 980 & 1150 & 1040 & 1480 & 1080 & 1150 & 800 & 710 \\
\hline $\mathrm{Sr}$ & 190 & 205 & 200 & 307 & 303 & 319 & 326 & 325 & 132 & 107 \\
\hline $\mathrm{Nb}$ & 10 & 14 & 35 & 21 & 20 & 18 & 21 & 19 & 9 & 11 \\
\hline $\mathrm{Zr}$ & 199 & 291 & 515 & 406 & 367 & 371 & 414 & 378 & 207 & 190 \\
\hline $\mathrm{Hf}$ & 12 & 17 & 27 & 23 & 20 & 21 & 22 & 22 & 12 & 11 \\
\hline$Y$ & 43 & 41 & 56 & 41 & 37 & 36 & 49 & 40 & 31 & 39 \\
\hline $\mathrm{Ga}$ & 39 & 41 & 37 & 36 & 35 & 36 & 37 & 42 & 42 & 37 \\
\hline $\mathrm{Zn}$ & 56 & 104 & 43 & 13 & 14 & 18 & 27 & 43 & 48 & 31 \\
\hline $\mathrm{Cu}$ & 13 & 18 & 5 & 3 & 0 & 3 & 3 & 4 & 8 & 4 \\
\hline $\mathrm{Ni}$ & 15 & 35 & 13 & 58 & 10 & 6 & 26 & 18 & 24 & 18 \\
\hline Co & 10 & 9 & 5 & 3 & 3 & 5 & 4 & 6 & 7 & 8 \\
\hline $\mathrm{Cr}$ & 18 & 35 & 67 & 37 & 3 & 6 & 8 & 6 & 55 & 15 \\
\hline V & 35 & 58 & 48 & 30 & 31 & 31 & 41 & 43 & 79 & 15 \\
\hline Sc & 11 & 14 & 13 & 11 & 9 & 11 & 14 & 12 & 11 & 6 \\
\hline $\mathrm{La}$ & 39 & 46 & 94 & 102 & 66 & 29 & 57 & 59 & 23 & 58 \\
\hline $\mathrm{Ce}$ & 80 & 124 & 209 & 200 & 97 & 54 & 109 & 109 & 42 & 121 \\
\hline $\mathrm{Nd}$ & 34 & 47 & 74 & 71 & 38 & 25 & 42 & 42 & 22 & 47 \\
\hline $\mathrm{Pb}$ & 69 & 67 & 56 & 59 & 58 & 57 & 63 & 70 & 70 & 77 \\
\hline Th & 17 & 21 & 36 & 15 & 15 & 11 & 15 & 14 & 10 & 14 \\
\hline$U$ & 1 & 3 & 6 & 3 & 3 & 4 & 3 & 2 & 0 & 5 \\
\hline
\end{tabular}

and three-phase aqueous-carbonic fluid inclusions of the LLV-type in amphibolite-facies rocks further south (Bedretto, Cavagnoli and Faido). Consistent phase proportions in all FIA demonstrate that the quartz crystals have trapped a homogeneous fluid, reflected by exceptionally low standard deviations for melting and homogenization temperatures obtained for each fluid inclusion assemblage, and even among all assemblages from a given locality (Table 4, Fig. 7). The two-phase aqueous fluid inclusions showed initial ice melting and final ice melting as well as total homogenization into the liquid phase. The aqueous fluid inclusions from Gauli, Gerstenegg, Tiefengletscher, and Vals never showed any clathrates despite excellent visibility, whereas Miron et al. (2013) have observed minor clathrate melting for few large fluid inclusions from Thusis (less than 0.1 vol.\% clathrate). The aqueous-carbonic fluid inclusions allowed measurement of final melting of $\mathrm{CO}_{2}$, final ice melting, final melting of clathrate, partial $\mathrm{CO}_{2}$ homogenization into the liquid (LLV to LL), and total homogenization into the liquid ( $\mathrm{LL}$ to $\mathrm{L}$ ).

The aqueous fluid inclusions have final ice-melting temperatures $\left(\mathrm{Tm}_{\text {ice }}\right)$ of -2.5 to $-2.2^{\circ} \mathrm{C}$ (Thusis), -1.7 to $-1.6^{\circ} \mathrm{C}$ (Vals), -3.0 to $-2.6^{\circ} \mathrm{C}$ (Gauli), -6.7 to $-6.5^{\circ} \mathrm{C}$ (Gerstenegg) and of -6.3 to $-5.1^{\circ} \mathrm{C}$ (Tiefengletscher). They have total homogenization temperatures of $130 \pm 2{ }^{\circ} \mathrm{C}$ (Thusis; Miron et al. 2013), $180 \pm 10^{\circ} \mathrm{C}$ (Vals), $151 \pm 6^{\circ} \mathrm{C}$ (Gauli), $185 \pm 3^{\circ} \mathrm{C}$ (Gerstenegg), and $210 \pm 7^{\circ} \mathrm{C}$ (Tiefengletscher). The aqueous-carbonic fluid inclusions have final $\mathrm{CO}_{2}$ melting temperatures $\left(\mathrm{Tm}_{\mathrm{CO}_{2}}\right)$ that are only slightly depressed compared to pure $\mathrm{CO}_{2}$, indicating that the concentrations of additional volatile species such as $\mathrm{CH}_{4}$ or $\mathrm{N}_{2}$ are low (Hollister \& Burrus 1976; Touret 1982; Thiery et al. 1994). The measured 
Table 3 Summary of input bulk rock and fluid compositions that were used for fluid-mineral equilibria modeling. For runs with pyrite in excess, 10 g of FeS 2 was added to the bulk composition.

\begin{tabular}{|c|c|c|c|c|c|}
\hline & Gauli & Gerstenegg & Tiefengletscher & Cavagnoli & Faido \\
\hline \multicolumn{6}{|l|}{ Rock part } \\
\hline $\mathrm{SiO}_{2}(\mathrm{~g})$ & 665.35 & 692.15 & 692.15 & 609.77 & 713.28 \\
\hline $\mathrm{Al}_{2} \mathrm{O}_{3}(\mathrm{~g})$ & 182.76 & 161.16 & 161.16 & 213.64 & 138.00 \\
\hline $\mathrm{Fe}_{2} \mathrm{O}_{3}(\mathrm{~g})$ & 9.47 & 14.77 & 14.77 & 27.35 & 16.39 \\
\hline $\mathrm{FeO}(\mathrm{g})$ & 4.73 & 5.78 & 5.78 & 2.15 & 8.07 \\
\hline $\mathrm{MgO}(\mathrm{g})$ & 4.69 & 4.82 & 4.82 & 6.23 & 3.85 \\
\hline $\mathrm{CaO}(\mathrm{g})$ & 26.11 & 27.92 & 27.92 & 3.35 & 12.19 \\
\hline $\mathrm{Na}_{2} \mathrm{O}(\mathrm{g})$ & 51.49 & 48.96 & 48.96 & 41.55 & 43.00 \\
\hline $\mathrm{K}_{2} \mathrm{O}(\mathrm{g})$ & 43.53 & 35.95 & 35.95 & 78.50 & 45.87 \\
\hline $\mathrm{H}_{2} \mathrm{O}(\mathrm{g})$ & 8.86 & 5.69 & 5.69 & 13.90 & 2.75 \\
\hline $\mathrm{CO}_{2}(\mathrm{~g})$ & 0.33 & 2.60 & 2.60 & 0.86 & 7.11 \\
\hline$C(g)$ & 2.68 & 0.21 & 0.21 & 2.69 & 0.05 \\
\hline$S(g)$ & 0 & 0 & 0 & 0 & 9.45 \\
\hline $\mathrm{Au}(\mathrm{g})$ & 0.01 & 0.01 & 0.01 & 0.01 & 0.01 \\
\hline Total & 1000 & 1000 & 1000 & 1000 & 1000 \\
\hline \multicolumn{6}{|l|}{ Fluid part } \\
\hline $\mathrm{H}_{2} \mathrm{O}(\mathrm{g})$ & 100 & 100 & 100 & 100 & 100 \\
\hline $\mathrm{CO}_{2}(\mathrm{~mol})$ & 0 & 0 & 0 & 1.754364 & 0.843377 \\
\hline $\mathrm{NaCl}(\mathrm{mol})$ & 0.084392 & 0.194386 & 0.176277 & 0.006872 & 0.060228 \\
\hline $\mathrm{H}_{2} \mathrm{~S}(\mathrm{~mol})$ & 0.000487 & 0.002362 & 0.001821 & 0.004885 & 0.007484 \\
\hline
\end{tabular}
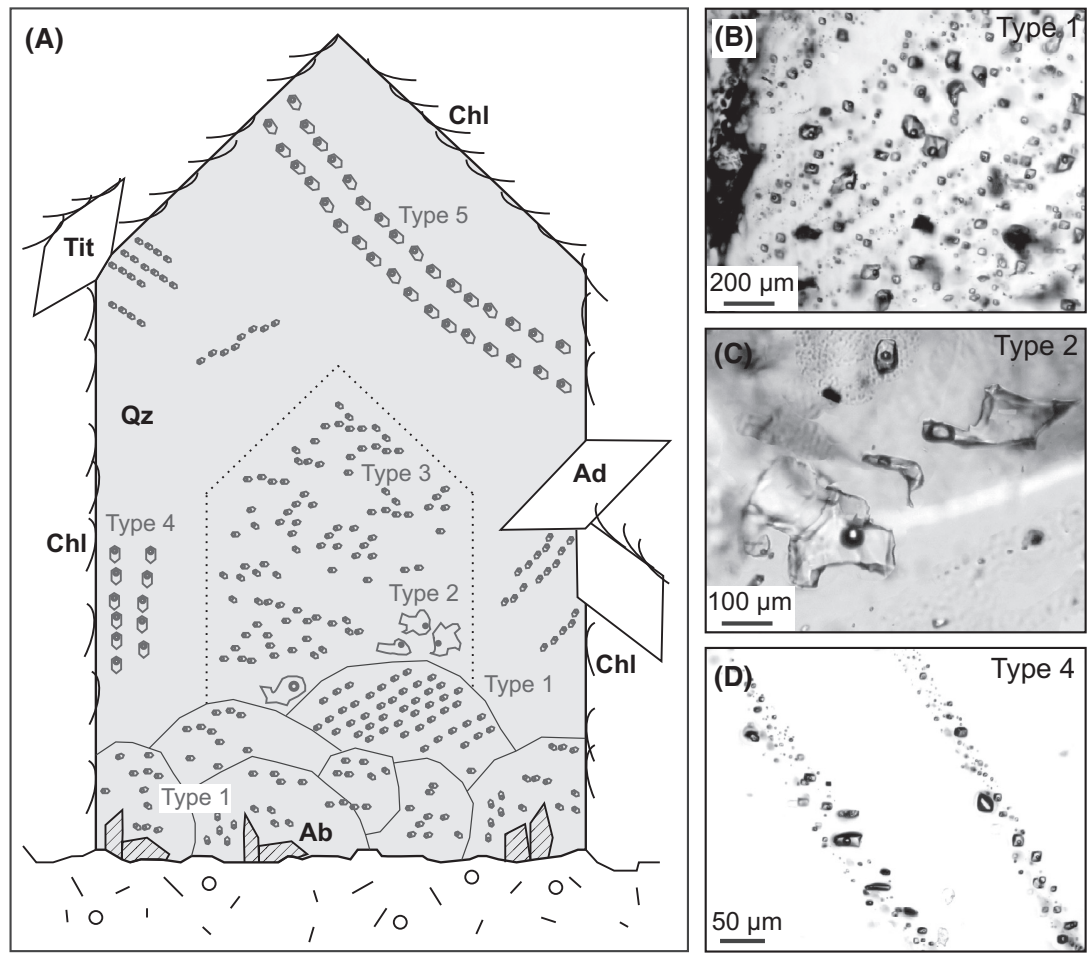

Fig. 4. Typical fluid inclusion assemblages (FIA) from Alpine fissure veins from Gauli and their time relationships. (A) Sketch map showing successive FIA relative to the quartz crystals' growth. The base of the crystal is composed of multiple quartz grains that contain abundant trails of pseudosecondary FIA (Type 1). This zone is followed by growth-zoned quartz hosting numerous pseudosecondary FIA (Type 2 and 3). The outer part of the quartz crystal hosts few pseudosecondary FIA (Type 4) and is crosscut by late trails with secondary FIA (Type 5). (B) Smaller aqueous (LV) fluid inclusions (Type 1) from quartz grains at the base of the crystal, corresponding to FIA A1 to A7 in Table 4. (C) Irregularly shaped aqueous (LV) fluid inclusions (Type 2) located in the central part of the crystal. (D) Trail of pseudosecondary aqueous (LV) fluid inclusions (Type 4) from the outer part of the crystal, corresponding to the FIA A8 to A14 in Table 4, which shows that all inclusion generations have nearly identical properties.
$\mathrm{Tm}_{\mathrm{CO}}$ are in the range of $-57.0^{\circ} \mathrm{C}$ (Bedretto), -57.3 to $-57.1^{\circ} \mathrm{C}$ (Cavagnoli), and -58.2 to $-57.9^{\circ} \mathrm{C}$ (Faido). Final clathrate melting temperatures $\left(\mathrm{Tm}_{\mathrm{Cla}}\right)$ are in the range of 8.9 to $9.8^{\circ} \mathrm{C}$ (Bedretto), 9.7 to $9.9^{\circ} \mathrm{C}$ (Cavagnoli), and 9.1 to $9.3^{\circ} \mathrm{C}$ (Faido). Based on the microthermometric data and estimates of the volume proportions, the $\mathrm{X}_{\mathrm{CO}_{2}}$ for the aqueous-carbonic fluid inclusions are calculated as $0.14,0.13$, and 0.13 for Bedretto, Cavagnoli, and Faido, respectively. The average total homogenization temperatures for the aqueous-carbonic fluid inclusions are systematically higher than those of the aqueous fluid inclusions, and are $285 \pm 10^{\circ} \mathrm{C}$ (Bedretto), $295 \pm 8^{\circ} \mathrm{C}$ (Cavagnoli) and $299 \pm 12^{\circ} \mathrm{C}$ (Faido), but they also homogenized into the liquid phase. The aqueous fluid 
Fig. 5. Fluid inclusion assemblages (FIA) from the Gerstenegg fissure vein and their relative time relationships. (A) Sketch map the time relations of different FIA relative to the quartz crystal growth. The growth-zoned quartz crystals contain pseudosecondary FIA (Type 1) in the central part and mostly secondary FIA (Type 2) in the outer part. The quartz crystals are overgrown by fluorite crystals with very small secondary FIA (Type 3). (B) Irregularly shaped aqueous (LV) fluid inclusions (Type 1) from the central part of the crystal, corresponding to FIA A1 to A3 in Table 4. (C) Trail with secondary aqueous (LV) fluid inclusions (Type 2) from the outer part of the quartz crystals, corresponding to FIA B1 to B3 in Table 4. (D) Small aqueous (LV) fluid inclusions (Type 3 ) in fluorite.

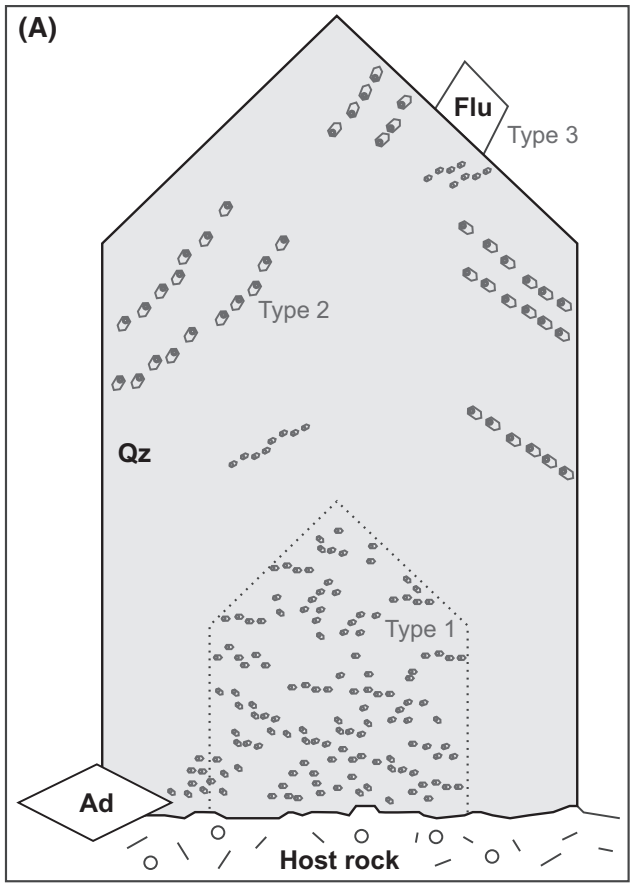

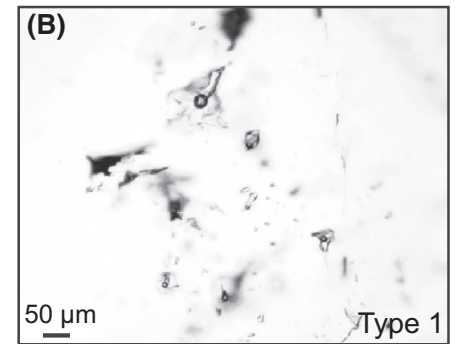
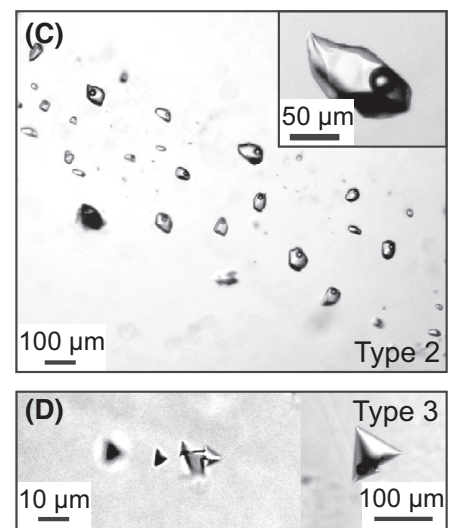

inclusions show a positive correlation between salinity and temperature of total homogenization (Fig. 7), whereas the aqueous-carbonic fluid inclusions do not show such a relationship.

\section{Elemental composition of fluid inclusions}

The elemental composition of 1007 individual fluid inclusions was analyzed by LA-ICPMS (192 from Gauli, 92 from Gerstenegg, 178 from Tiefengletscher, 57 from Vals, 62 from Bedretto, 220 from Cavagnoli, and 206 from Faido). The data were combined with those from Miron et al. (2013) and Rauchenstein-Martinek et al. (2014). The multi-element fluid inclusion LA-ICPMS data are summarized in Table 4 and illustrated in Figs 811 (the full dataset including all microthermometric and LA-ICPMS results for the individual FI grouped by assemblages and fluid inclusion types are listed in the Data S1). The LA-ICPMS fluid inclusion data that were obtained with the short element menu optimized for halogen analysis are listed in Table 5 . Figure 8 gives an overview of the elemental concentrations and illustrates that the fluids are compositionally homogeneous at each investigated locality, but that fluid compositions vary considerably between localities.

For all localities, the most abundant cation components are $\mathrm{Na}, \mathrm{K}$, and $\mathrm{Ca}$. As expected for low to intermediate salinity fluids, the concentrations of a number of alkaline and alkaline earth elements $(\mathrm{Li}, \mathrm{K}, \mathrm{Rb}, \mathrm{Cs}, \mathrm{Sr}$, and $\mathrm{Ba})$ correlate positively with the bulk fluid salinity (Fig. 10) and there are positive correlations among the different alkali metals (Fig. 11). All fluid inclusions contain detectable concentrations of $\mathrm{S}, \mathrm{As}, \mathrm{Sb}$, and $\mathrm{B}$. The sulfur concentrations increase from north (Thusis: $300 \mathrm{ppm}$ ) to south (Faido: $2210 \mathrm{ppm}$ ), that is sulfur correlates with the increase in metamorphic grade of the host rocks. Arsenic follows a similar trend, with the highest As contents measured in the low-salinity, high-sulfur inclusions of Cavagnoli $(240 \mathrm{ppm})$. The As concentrations show a good positive correlation with the $S$ concentrations (Fig. 11F) and a fair positive correlation with the $S b$ concentrations (Fig. 11D). The fluid inclusions from all localities have considerable $\mathrm{B}$ concentrations, which are typically on the order of 170 to $960 \mathrm{ppm}$. The B concentrations do not correlate with fluid salinity or the metamorphic grade and are not systematically different between aqueous and aqueous-carbonic fluid inclusions.

The dataset is more limited for $\mathrm{Mg}, \mathrm{Fe}$, and $\mathrm{Mn}$, because in many fluid inclusions, these elements were below their limits of detection. The concentrations of all three elements are typically on the order of few ppm, except in the samples from Tiefengletscher that had an order of magnitude higher concentrations of $\mathrm{Fe}$ and $\mathrm{Mn}$. The ore metals $\mathrm{Cu}, \mathrm{Zn}$, and $\mathrm{Pb}$ were detected in the majority of fluid inclusion assemblages. There are positive correlations between $\mathrm{Pb}$ and $\mathrm{Zn}$ (Fig. 11E) and between $\mathrm{Cu}$ and $\mathrm{Zn}$ (Fig. 11G), a feature that has been reported before for $\mathrm{Pb}$ and $\mathrm{Zn}$ in data compilations for a broad range of crustal fluids (Yardley 2005, 2013). 
Table 4 Average elemental composition, melting temperatures (ice, carbon dioxide, and clathrate) and homogenization (carbon dioxide, total) temperatures of all analyzed fluid inclusion assemblages (FIA).

\begin{tabular}{|c|c|c|c|c|c|c|c|c|c|c|c|c|c|c|}
\hline FIA & Type & $\begin{array}{l}\# \\
\mathrm{FI}\end{array}$ & $\begin{array}{l}\mathrm{Li} \\
(\mathrm{ppm})\end{array}$ & $\begin{array}{l}\mathrm{Na} \\
(\mathrm{ppm})\end{array}$ & $\begin{array}{l}\text { K } \\
\text { (ppm) }\end{array}$ & $\begin{array}{l}\text { Rb } \\
\text { (ppm) }\end{array}$ & $\begin{array}{l}\text { Cs } \\
(\mathrm{ppm})\end{array}$ & $\begin{array}{l}\text { Mg } \\
(\mathrm{ppm})\end{array}$ & $\begin{array}{l}\mathrm{Ca} \\
(\mathrm{ppm})\end{array}$ & $\begin{array}{l}\text { Sr } \\
(p p m)\end{array}$ & $\begin{array}{l}\mathrm{Ba} \\
(\mathrm{ppm})\end{array}$ & $\begin{array}{l}\text { B } \\
(\mathrm{ppm})\end{array}$ & $\begin{array}{l}\mathrm{Al} \\
(\mathrm{ppm})\end{array}$ & $\begin{array}{l}\mathrm{Fe} \\
(\mathrm{ppm})\end{array}$ \\
\hline \multicolumn{15}{|l|}{ Gauli } \\
\hline $\mathrm{A} 1$ & 1 & 7 & 180 & 14400 & 4340 & 30 & 7.7 & & 1560 & 36 & 4.0 & 650 & 83 & \\
\hline $\mathrm{A} 2$ & 1 & 3 & 210 & 15100 & 3850 & 34 & 7.6 & 0.20 & 870 & 38 & 4.4 & 550 & & \\
\hline $\mathrm{A} 3$ & 1 & 7 & 230 & 13800 & 3860 & 30 & 7.0 & 0.27 & 1660 & 37 & 4.2 & 540 & 24 & \\
\hline A4 & 1 & 4 & 200 & 14300 & 4160 & 31 & 7.3 & & 1650 & 36 & 4.8 & 710 & 44 & \\
\hline A5 & 1 & 4 & 250 & 13100 & 3270 & 24 & 5.7 & & 4870 & 42 & 4.1 & 420 & 73 & \\
\hline A6 & 1 & 4 & 150 & 14800 & 3310 & 28 & 5.9 & & 1360 & 45 & 3.4 & 480 & & \\
\hline A7 & 1 & 1 & 130 & 11900 & 4510 & 26 & 6.9 & & 3270 & 15 & 1.8 & 600 & 13 & \\
\hline A8 & 4 & 18 & 160 & 14800 & 4520 & 31 & 7.2 & & 1520 & 34 & 5.3 & 650 & 62 & \\
\hline A9 & 4 & 3 & 180 & 14100 & 2370 & 23 & 3.2 & & 5400 & 68 & 6.4 & 460 & 30 & \\
\hline A10 & 4 & 3 & 160 & 15200 & 4530 & 31 & 8.9 & & 560 & 20 & 3.2 & 680 & 49 & \\
\hline A11 & 2 & 9 & 110 & 14500 & 3950 & 29 & 7.1 & & 1710 & 41 & 4.2 & 680 & 53 & \\
\hline A12 & 2 & 2 & 140 & 15000 & 3220 & 36 & 6.8 & & 2440 & 35 & 7.0 & 510 & & \\
\hline A13 & 2 & 1 & 140 & 15800 & 2160 & 30 & 4.4 & & 1090 & 52 & 7.2 & 600 & 200 & \\
\hline A14 & 2 & 10 & 120 & 14100 & 3660 & 24 & 6.5 & & 2450 & 30 & 3.6 & 510 & 54 & \\
\hline B1 & 3 & 9 & 100 & 14700 & 4400 & 12 & 2.8 & 11 & 810 & 13 & 10 & 550 & 32 & \\
\hline $\mathrm{C} 1$ & 3 & 5 & 160 & 15100 & 4700 & 34 & 7.8 & 0.51 & 930 & 43 & 4.6 & 580 & 43 & \\
\hline $\mathrm{C} 2$ & 3 & 2 & 150 & 14700 & 2750 & 27 & 6.4 & 0.45 & 2230 & 67 & 6.0 & 540 & 46 & \\
\hline $\mathrm{C} 3$ & 3 & 1 & 150 & 15100 & 4110 & 33 & 7.9 & & 1160 & 39 & 4.8 & 600 & 5.6 & \\
\hline $\mathrm{C} 4$ & 3 & 3 & 140 & 15100 & 4050 & 31 & 6.8 & & 1840 & 51 & 4.6 & 550 & 5.0 & \\
\hline $\mathrm{C} 5$ & 3 & 5 & 120 & 14600 & 4250 & 37 & 8.7 & 0.26 & 1540 & 45 & 4.4 & 640 & 43 & \\
\hline $\mathrm{C} 6$ & 3 & 4 & 150 & 14800 & 4950 & 36 & 7.7 & 0.01 & 1010 & 25 & 2.1 & 610 & 48 & 46 \\
\hline $\mathrm{C7}$ & 3 & 2 & 160 & 15100 & 4690 & 34 & 8.6 & & 890 & 34 & 3.8 & 670 & 14 & \\
\hline $\mathrm{C} 8$ & 3 & 3 & 120 & 15200 & 3930 & 33 & 7.7 & & 1240 & 42 & 4.6 & 580 & 52 & \\
\hline \multicolumn{15}{|c|}{ Gerstenegg } \\
\hline $\mathrm{A} 1$ & 1 & 13 & 160 & 26700 & 9780 & 140 & 26 & 5.0 & 5750 & 230 & 34 & 380 & 36 & 23 \\
\hline $\mathrm{A} 2$ & 1 & 11 & 170 & 27570 & 7950 & 130 & 34 & 6.6 & 7560 & 260 & 35 & 350 & 61 & 23 \\
\hline $\mathrm{A} 3$ & 1 & 2 & 150 & 29200 & 5620 & 87 & 28 & 1.8 & 9700 & 290 & 32 & 310 & 24 & 54 \\
\hline B1 & 2 & 10 & 160 & 28000 & 9450 & 130 & 24 & 10 & 5520 & 200 & 25 & 310 & 20 & 94 \\
\hline B2 & 2 & 6 & 150 & 24000 & 8100 & 91 & 33 & 8.1 & 8700 & 210 & 37 & 260 & & \\
\hline B3 & 2 & 6 & 220 & 27300 & 8410 & 130 & 25 & 6.1 & 6400 & 250 & 33 & 300 & 90 & 14 \\
\hline $\mathrm{C} 1$ & 2 & 7 & 200 & 34000 & 8790 & 35 & 6.4 & 6.7 & 1770 & 110 & 110 & 200 & & \\
\hline $\mathrm{C} 2$ & 2 & 4 & 130 & 27400 & 5820 & 90 & 21 & 6.3 & 8480 & 290 & 31 & 290 & 43 & \\
\hline $\mathrm{C} 3$ & 2 & 2 & 160 & 33500 & 8990 & 35 & 6.7 & & 3080 & 180 & 170 & 270 & & \\
\hline \multicolumn{15}{|c|}{ Tiefengletscher } \\
\hline $\mathrm{A} 1$ & 1 & 7 & 220 & 28600 & 11000 & 81 & 13 & 3.8 & 1740 & 55 & 21 & 250 & 81 & 99 \\
\hline $\mathrm{A} 2$ & 1 & 3 & 250 & 28000 & 11100 & 84 & 9.2 & & 2620 & 33 & 23 & 250 & 57 & 150 \\
\hline $\mathrm{A} 3$ & 1 & 7 & 230 & 28500 & 9870 & 95 & 13 & 4.0 & 1810 & 98 & 19 & 210 & 10 & 52 \\
\hline A4 & & 8 & 260 & 27300 & 12000 & 88 & 15 & 1.5 & 1800 & 30 & 22 & 280 & 68 & 140 \\
\hline B1 & 2 & 8 & 240 & 26700 & 13600 & 76 & 12 & 4.6 & 1800 & 34 & 22 & 230 & 32 & 51 \\
\hline B2 & 2 & 4 & 230 & 26500 & 13000 & 74 & 11 & 5.1 & 1580 & 32 & 20 & 220 & 130 & 80 \\
\hline B3 & 2 & 9 & 260 & 27600 & 12200 & 100 & 16 & 4.6 & 1980 & 91 & 16 & 250 & 34 & 100 \\
\hline B4 & 2 & 3 & 230 & 27100 & 12400 & 85 & 12 & 3.6 & 2030 & 81 & 20 & 260 & 130 & 70 \\
\hline B5 & 2 & 3 & 230 & 27800 & 11500 & 88 & 17 & 2.5 & 1930 & 88 & 10 & 250 & 3.6 & 67 \\
\hline B6 & 2 & 1 & 260 & 22400 & 19300 & 59 & 12 & 1.4 & 2630 & 22 & 21 & 170 & & 180 \\
\hline $\mathrm{C} 1$ & 3 & 3 & 260 & 28600 & 12700 & 75 & 14 & 2.0 & 910 & 39 & 22 & 290 & 38 & 140 \\
\hline $\mathrm{C} 2$ & 3 & 4 & 260 & 27200 & 8790 & 54 & 10 & 6.9 & 3290 & 95 & 76 & 200 & 110 & 130 \\
\hline $\mathrm{C} 3$ & 3 & 4 & 240 & 28400 & 10700 & 62 & 10 & 1.6 & 1600 & 45 & 25 & 230 & 64 & 84 \\
\hline $\mathrm{C} 4$ & 3 & 3 & 250 & 28400 & 12200 & 76 & 13 & 3.0 & 1550 & 36 & 23 & 260 & 50 & 94 \\
\hline C5 & 3 & 6 & 260 & 25800 & 11700 & 100 & 14 & 1.5 & 1900 & 66 & 25 & 260 & 46 & 160 \\
\hline C6 & 3 & 2 & 290 & 27300 & 12500 & 88 & 13 & & 1880 & 37 & 28 & 340 & 41 & 100 \\
\hline$C 7$ & 3 & 1 & 230 & 23100 & 10900 & 60 & 8.7 & 12 & 6350 & 29 & 15 & 250 & 110 & 180 \\
\hline $\mathrm{C} 8$ & 3 & 1 & 220 & 27800 & 12300 & 89 & 15 & 1.6 & 1510 & 38 & 22 & 250 & 36 & 57 \\
\hline \multicolumn{15}{|c|}{ Cavagnoli } \\
\hline $\mathrm{A} 1$ & 1 & 7 & 7 & 680 & 22 & 0.32 & 0.15 & 4.1 & 730 & 0.05 & 0.2 & 200 & 23 & 3 \\
\hline $\mathrm{A} 2$ & 1 & 4 & 7 & 760 & & 0.3 & 0.17 & 4.4 & 610 & 0.05 & & 240 & 16 & \\
\hline $\mathrm{A} 3$ & 1 & 2 & 9 & 1010 & 67 & 0.8 & 0.18 & & 430 & 0.20 & 0.4 & 300 & 82 & \\
\hline A4 & 1 & 2 & 4 & 1260 & & 0.7 & 0.80 & & & 0.18 & & 410 & 6.0 & \\
\hline A5 & 1 & 1 & 3 & 500 & 93 & 0.5 & 0.11 & & 660 & 3.1 & & 180 & & \\
\hline A6 & 1 & 7 & 4 & 1080 & & 0.7 & 0.29 & & 580 & 0.27 & & 330 & 27 & \\
\hline B1 & 1 & 4 & 12 & 630 & 39 & 0.4 & 0.23 & & 980 & 0.02 & 0.5 & 140 & 48 & \\
\hline B2 & 1 & 9 & 49 & 1020 & 76 & 0.6 & 0.19 & & & 0.27 & & 260 & 71 & \\
\hline B3 & 1 & 4 & 4 & 1020 & 63 & 0.5 & 0.52 & 2.2 & & 0.02 & 0.9 & 370 & 75 & 8 \\
\hline B4 & 1 & 3 & 9 & 1100 & 70 & 0.7 & 0.31 & & & 0.27 & 1.4 & 350 & 160 & \\
\hline B5 & 1 & 1 & & 1250 & 94 & 0.8 & 0.20 & 1.1 & & & 0.5 & 320 & 71 & \\
\hline
\end{tabular}




\begin{tabular}{|c|c|c|c|c|c|c|c|c|c|c|c|c|c|c|c|}
\hline $\begin{array}{l}\mathrm{Mn} \\
(\mathrm{ppm})\end{array}$ & $\begin{array}{l}\mathrm{Cu} \\
(\mathrm{ppm})\end{array}$ & $\begin{array}{l}\text { Zn } \\
\text { (ppm) }\end{array}$ & $\begin{array}{l}\mathrm{Pb} \\
(\mathrm{ppm})\end{array}$ & $\begin{array}{l}\mathrm{Ag} \\
(\mathrm{ppm})\end{array}$ & $\begin{array}{l}\text { As } \\
\text { (ppm) }\end{array}$ & $\begin{array}{l}\mathrm{Sb} \\
(\mathrm{ppm})\end{array}$ & $\begin{array}{l}\mathrm{Ti} \\
(\mathrm{ppm})\end{array}$ & $\begin{array}{l}\text { S } \\
(\mathrm{ppm})\end{array}$ & $\begin{array}{l}\mathrm{Cl} \\
(\mathrm{ppm})\end{array}$ & $\begin{array}{l}\mathrm{Br} \\
(\mathrm{ppm})\end{array}$ & $\begin{array}{l}\mathrm{Tm}_{\mathrm{CO}_{2}} \\
\left({ }^{\circ} \mathrm{C}\right)\end{array}$ & $\begin{array}{l}\mathrm{Tm}_{\text {ice }} \\
\left({ }^{\circ} \mathrm{C}\right)\end{array}$ & $\begin{array}{l}\operatorname{Tm}_{\mathrm{Cla}} \\
\left({ }^{\circ} \mathrm{C}\right)\end{array}$ & $\begin{array}{l}\mathrm{Th}_{\mathrm{CO}_{2}} \\
\left({ }^{\circ} \mathrm{C}\right)\end{array}$ & $\begin{array}{l}\mathrm{Th}_{\text {tot }} \\
\left({ }^{\circ} \mathrm{C}\right)\end{array}$ \\
\hline 13 & 2.5 & 11 & 0.43 & 0.07 & 3.8 & 7.1 & & 420 & 35000 & 290 & & -2.9 & & & 150 \\
\hline \multirow[t]{2}{*}{3.0} & & 2.0 & 0.14 & & 1.1 & 3.5 & & 280 & 29200 & 180 & & -2.9 & & & 149 \\
\hline & 2.2 & 6.8 & 0.49 & & 1.5 & 7.3 & & 160 & 28900 & 160 & & -2.9 & & & 153 \\
\hline \multirow{2}{*}{11} & & & & & 1.0 & 7.0 & & 230 & 27200 & 130 & & -2.8 & & & \\
\hline & & & & & 3.4 & 10 & & 410 & 32900 & 100 & & -2.8 & & & \\
\hline \multirow[t]{9}{*}{2.4} & & & & 0.28 & 0.93 & 4.3 & & 220 & 25400 & 150 & & -2.8 & & & \\
\hline & & & & & 3.0 & & & & 20500 & 98 & & -2.8 & & & \\
\hline & & 13 & 0.47 & & 5.3 & 7.0 & 15 & 360 & 31400 & 220 & & -2.8 & & & 146 \\
\hline & & & 0.59 & & & & & & 27400 & 140 & & -2.8 & & & \\
\hline & & 6.0 & 0.39 & & 2.7 & 7.1 & & 390 & 32600 & 77 & & -2.8 & & & \\
\hline & & 16 & 0.77 & 0.38 & 7.3 & 8.7 & & 400 & 30200 & & & -2.7 & & & 143 \\
\hline & & & & & 5.0 & & & 890 & 25300 & 280 & & -2.8 & & & \\
\hline & & 21 & & & & & & & 44200 & & & -2.8 & & & \\
\hline & 5.5 & 20 & & 0.57 & 9.8 & & 20 & 610 & 29400 & 200 & & -2.8 & & & 153 \\
\hline \multirow[t]{2}{*}{6.0} & & & & & & 7.8 & & 340 & 27900 & 190 & & -2.6 & & & 145 \\
\hline & & & & & & 3.3 & 1.5 & 140 & 24200 & 81 & & -2.7 & & & 144 \\
\hline \multirow[t]{3}{*}{0.6} & & & & & & 1.2 & & 71 & 24600 & 40 & & -2.8 & & & 146 \\
\hline & & & & & & 3.0 & & 140 & 27600 & 46 & & -2.7 & & & 146 \\
\hline & & & & & & 2.3 & 1.4 & 340 & 29100 & 120 & & -2.7 & & & 144 \\
\hline \multirow[t]{3}{*}{0.4} & & & & & & 2.4 & 0.58 & 160 & 31400 & 110 & & -2.8 & & & 148 \\
\hline & & & & & & 3.5 & & 180 & 28200 & 73 & & -2.7 & & & 163 \\
\hline & & & & & & 3.2 & 0.82 & 170 & 26700 & 45 & & -2.8 & & & \\
\hline 0.3 & & & & & & 2.9 & 1.3 & 160 & 26900 & 52 & & -2.8 & & & \\
\hline 23 & & 6.0 & 6.0 & 1.0 & 40 & 1.0 & 3 & 150 & 52500 & 210 & & -6.6 & & & 185 \\
\hline 15 & & 200 & 2.1 & 1.4 & 17 & 0.85 & 6.2 & 270 & 61500 & 350 & & -6.9 & & & 185 \\
\hline 2.2 & & & 0.44 & 0.19 & 2.5 & 0.54 & & 320 & 57300 & 180 & & -6.6 & & & 185 \\
\hline 19 & 8.6 & 41 & 4.6 & 1.0 & 35 & 3.8 & 24 & 190 & 52900 & 680 & & -6.5 & & & 187 \\
\hline 11 & 10 & 21 & 3.1 & & 15 & & 36 & 570 & 42900 & 750 & & -6.5 & & & 186 \\
\hline 19 & 47 & 61 & 11 & 1.7 & 29 & 2.6 & 24 & 1440 & 41700 & 1100 & & -6.5 & & & \\
\hline 42 & 53 & 36 & 28 & & 34 & 6.1 & 61 & 930 & 52300 & 630 & & -6.6 & & & 186 \\
\hline \multirow[t]{2}{*}{12} & & & 7.5 & & 15 & 3.3 & & & 43900 & 420 & & -6.7 & & & \\
\hline & & & 58 & & 38 & & & & 53300 & 240 & & -6.5 & & & \\
\hline 49 & 160 & 14 & 38 & 1.0 & 49 & 4.5 & 3.1 & 390 & 50700 & 220 & & -6.0 & & & 208 \\
\hline 64 & 200 & 45 & 64 & 0.71 & 56 & 5.9 & & 640 & 52500 & 230 & & -6.2 & & & \\
\hline 46 & 93 & 13 & 26 & 0.70 & 42 & 5.6 & 2.1 & 320 & 48600 & 130 & & -6.2 & & & 208 \\
\hline 82 & 270 & 36 & 52 & 1.8 & 58 & 10 & 1.6 & 550 & 45700 & 240 & & -6.1 & & & \\
\hline 54 & 190 & 17 & 39 & 1.0 & 43 & 2.8 & 4.4 & 670 & 50700 & 210 & & -6.1 & & & 216 \\
\hline 62 & 180 & 14 & 38 & 0.63 & 44 & 2.4 & 3.0 & 620 & 43100 & 130 & & -6.2 & & & \\
\hline 55 & 150 & 14 & 41 & 0.86 & 63 & 3.1 & 3.0 & 430 & 50700 & 130 & & -6.1 & & & 215 \\
\hline 57 & 130 & 16 & 33 & 0.40 & 47 & 2.7 & 5.9 & 250 & 44600 & 200 & & -5.9 & & & \\
\hline 56 & 92 & 20 & 50 & 0.64 & 57 & 4.6 & 2.0 & 290 & 52300 & 110 & & -6.2 & & & \\
\hline 190 & 230 & 17 & 63 & 0.76 & 92 & 4.3 & & 170 & 51700 & 820 & & -6.2 & & & \\
\hline 78 & 220 & 10 & 42 & 1.0 & 56 & 3.1 & 2.0 & 660 & 52300 & 180 & & -6.2 & & & 211 \\
\hline 82 & 56 & 23 & 38 & 0.24 & 44 & 4.1 & 8.4 & 180 & 46300 & 220 & & -6.2 & & & \\
\hline 59 & 130 & 20 & 38 & 1.1 & 42 & 3.3 & 13 & 550 & 49600 & 280 & & -6.2 & & & 212 \\
\hline 71 & 220 & 13 & 39 & 1.0 & 60 & 3.0 & & 700 & 45500 & 220 & & -6.3 & & & 202 \\
\hline 90 & 300 & 28 & 51 & 1.7 & 80 & 3.6 & 17 & 910 & 43600 & 300 & & -6.1 & & & \\
\hline 76 & 190 & 25 & 63 & 1.6 & 85 & 7.2 & 1.2 & 660 & & 200 & & -6.1 & & & \\
\hline 82 & 150 & 27 & 34 & 0.78 & 48 & & & & 34400 & 270 & & -6.1 & & & \\
\hline \multirow[t]{5}{*}{56} & 190 & 14 & 39 & 0.83 & 44 & 3.4 & & 510 & & 76 & & -6.1 & & & \\
\hline & 1.5 & 5.6 & 0.08 & 0.24 & 82 & 1.4 & 18 & 510 & & & -57.0 & & 9.9 & 27.4 & \\
\hline & & & 0.08 & 0.03 & 170 & 4.1 & & 630 & 290 & & -57.0 & & 9.9 & 26.8 & \\
\hline & & & & & 250 & 6.3 & 25 & 870 & & & -57.0 & & 9.8 & & \\
\hline & & & 0.04 & & 150 & 4.3 & & 910 & 270 & & -57.1 & & 9.9 & & \\
\hline \multirow[t]{7}{*}{18} & 12 & 27 & 2.9 & 0.64 & 130 & 5.1 & & 820 & & & & & 9.9 & & \\
\hline & & & & 0.24 & 200 & 4.7 & & 450 & 340 & & -57.0 & & 9.9 & 28.1 & 295 \\
\hline & & 0.5 & 0.10 & & 110 & 2.9 & & 500 & & & -57.1 & & 9.9 & 27.5 & \\
\hline & & 2.9 & 0.55 & 0.35 & 190 & 5.5 & & 870 & 3740 & 170 & -57.0 & & 9.9 & & \\
\hline & 0.6 & 0.5 & 0.17 & 0.09 & 280 & 6.0 & & 1120 & & & -57.1 & & 9.9 & 26.9 & \\
\hline & & 2.5 & 0.36 & 0.12 & 270 & 4.3 & & 900 & & & -57.1 & & 9.9 & & \\
\hline & & & & & 240 & 7.0 & & 930 & & & -57.0 & & 9.8 & & \\
\hline
\end{tabular}


Table 4 Continued.

\begin{tabular}{|c|c|c|c|c|c|c|c|c|c|c|c|c|c|c|}
\hline $\mathrm{FIA}$ & Type & $\begin{array}{l}\# \\
\mathrm{FI}\end{array}$ & $\begin{array}{l}\mathrm{Li} \\
(\mathrm{ppm})\end{array}$ & $\begin{array}{l}\mathrm{Na} \\
(\mathrm{ppm})\end{array}$ & $\begin{array}{l}\text { K } \\
(\mathrm{ppm})\end{array}$ & $\begin{array}{l}\mathrm{Rb} \\
(\mathrm{ppm})\end{array}$ & $\begin{array}{l}\text { Cs } \\
\text { (ppm) }\end{array}$ & $\begin{array}{l}\mathrm{Mg} \\
(\mathrm{ppm})\end{array}$ & $\begin{array}{l}\mathrm{Ca} \\
(\mathrm{ppm})\end{array}$ & $\begin{array}{l}\mathrm{Sr} \\
(\mathrm{ppm})\end{array}$ & $\begin{array}{l}\mathrm{Ba} \\
(\mathrm{ppm})\end{array}$ & $\begin{array}{l}\text { B } \\
(\mathrm{ppm})\end{array}$ & $\begin{array}{l}\mathrm{Al} \\
(\mathrm{ppm})\end{array}$ & $\begin{array}{l}\mathrm{Fe} \\
(\mathrm{ppm})\end{array}$ \\
\hline B6 & 1 & 1 & & 1270 & 61 & 0.7 & 0.24 & & & 0.08 & & 380 & 27 & \\
\hline $\mathrm{C} 1$ & 2 & 10 & 14 & 910 & 72 & 0.7 & 0.64 & 0.7 & & 0.28 & 1.4 & 320 & 31 & 10 \\
\hline $\mathrm{C} 2$ & 2 & 7 & 15 & 860 & 94 & 1.2 & 0.46 & 0.7 & 260 & & 2.4 & 430 & 17 & 58 \\
\hline $\mathrm{C} 3$ & 2 & 2 & 11 & 1030 & 78 & 0.7 & 0.17 & & & & & 470 & 49 & \\
\hline D1 & 3 & 4 & 21 & 1060 & 25 & 0.6 & 0.33 & 11.7 & & & & 340 & 57 & \\
\hline D2 & 3 & 3 & 5 & 1060 & 44 & 0.6 & 0.30 & 1.8 & & 0.45 & & 430 & & \\
\hline D3 & 3 & 8 & 7 & 730 & 57 & 0.7 & 0.22 & 0.7 & & & & 270 & 10 & \\
\hline D4 & 3 & 6 & 9 & 1000 & 74 & 0.6 & 0.68 & & & & 1.3 & 380 & 30 & \\
\hline D5 & 3 & 1 & 5 & 1070 & & 0.5 & 0.41 & & & & & 320 & 33 & \\
\hline D6 & 3 & 1 & 2 & 1060 & 46 & 0.6 & 0.36 & & & & & 470 & 18 & \\
\hline \multicolumn{15}{|l|}{ Faido } \\
\hline $\mathrm{A} 1$ & 1 & 4 & 50 & 5730 & 1930 & 38 & 12 & 4.1 & & 7.0 & 2.3 & 450 & 84 & 37 \\
\hline $\mathrm{A} 2$ & 1 & 9 & 28 & 10100 & 2750 & 18 & 5 & 1.9 & 280 & 3.8 & 3.4 & 860 & 54 & 110 \\
\hline A4 & 1 & 3 & 23 & 9550 & 2330 & 27 & 14 & 14 & 41 & 7.3 & 1.7 & 650 & & 23 \\
\hline B1 & 2 & 9 & 33 & 9140 & 2920 & 24 & 17 & 3.5 & 1500 & 5.1 & 2.4 & 560 & 150 & 63 \\
\hline B2 & 2 & 6 & 25 & 10600 & 2490 & 22 & 20 & 0.6 & 430 & 7.1 & 1.2 & 700 & 110 & 59 \\
\hline B3 & 2 & 2 & 26 & 10500 & 2940 & 21 & 4 & & & 1.7 & 0.3 & 970 & 25 & 82 \\
\hline B4 & 2 & 4 & 26 & 9940 & 2300 & 16 & 19 & 1.1 & 1580 & 8.4 & 1.2 & 670 & 41 & 86 \\
\hline B5 & 2 & 6 & 54 & 10600 & 2420 & 19 & 10 & 6.7 & 540 & 9.7 & 4.0 & 720 & 100 & 77 \\
\hline B6 & 2 & 4 & 36 & 10500 & 2850 & 26 & 20 & 1.9 & & 7.1 & 1.9 & 830 & 98 & 160 \\
\hline B7 & 3 & 5 & 28 & 10100 & 3050 & 18 & 4 & 0.9 & 390 & 1.3 & & 930 & 120 & 61 \\
\hline B8 & 3 & 3 & 18 & 10800 & 2240 & 26 & 29 & 3.6 & 96 & 9.5 & 1.0 & 410 & 140 & \\
\hline B9 & 3 & 3 & 23 & 9340 & 2360 & 24 & 13 & 43 & 1270 & 5.7 & 1.9 & 550 & 34 & \\
\hline B10 & 3 & 3 & 25 & 9950 & 2710 & 26 & 12 & 69 & 1700 & 5.7 & & 540 & 140 & \\
\hline B11 & 3 & 5 & 25 & 10200 & 2680 & 21 & 21 & 1.0 & 840 & 9.3 & 1.7 & 550 & 110 & 190 \\
\hline
\end{tabular}

The complete dataset is provided in the Data S1.

Concentrations of $\mathrm{Al}$ and $\mathrm{Ti}$ are in the range of 45$89 \mathrm{ppm}$ and 5-26 ppm, respectively, in all investigated FIA's. Both elements do not show any clear correlation with salinity and the lithology of the host rock. Titanium is also present as trace element $(1-5 \mathrm{ppm})$ in the quartz hosting the fluid inclusions, and it was therefore only possible to quantify Ti concentrations in some fluid inclusions where we observed a well-defined Ti peak that closely followed the shape of the large $\mathrm{Na}$ peak. The $\mathrm{Ti}$ and $\mathrm{Al}$ in the host quartz were monitored immediately before breaching the fluid inclusions and after the inclusion was opened, and we can subtract the host background and reliably quantify concentrations in inclusions where clear peaks significantly above the host background were detected.

The concentrations of $\mathrm{Cl}$ and $\mathrm{Br}$ were analyzed as part of the multi-element menu, but we also performed additional measurements on fluid inclusions from selected assemblages with an element menu that was optimized for higher precision analysis of the $\mathrm{Cl} / \mathrm{Br}$ ratio (Seo et al. 2011). The plot of the molar $\mathrm{Cl} / \mathrm{Br}$ ratios (Fig. 9) shows that the measurements with the shorter optimized element menu have smaller analytical errors, but that the average $\mathrm{Cl} / \mathrm{Br}$ ratio of the fluid from each fissure vein is essentially the same for both sets of analyses (Fig. 9). Measured $\mathrm{Cl}$ and $\mathrm{Br}$ concentrations in each inclusion were first converted into molar values. The molar $\mathrm{Cl} / \mathrm{Br}$ ratios were then averaged for each fluid inclusion assemblage and also for all assemblages from each fissure vein. Average molar $\mathrm{Cl} / \mathrm{Br}$ values are $350 \pm 160$ for Gauli, $440 \pm 200$ for Gerstenegg, and $510 \pm 30$ for Tiefengletscher, whereas average values are $100 \pm 55$ for Cavagnoli, $20 \pm 30$ for Bedretto, and $140 \pm 50$ for Faido.

\section{FLUID-ROCK EQUILIBRIA MODELING AND PRESSURE-TEMPERATURE EVOLUTION}

We have combined chemical solute thermometry, fluid inclusion isochores, and constraints from fluid-mineral equilibria modeling to estimate the pressure-temperature conditions of the Alpine fissure veins and to compare these with published data for the metamorphic P-T path of their host rocks. The peak metamorphic conditions of the host rocks were adopted from Todd \& Engi (1997). They are $430-470^{\circ} \mathrm{C}$ and $4-6 \mathrm{kbar}$ for Gauli, 420 $460^{\circ} \mathrm{C}$ and $3-5 \mathrm{kbar}$ for Gerstenegg, $420-480^{\circ} \mathrm{C}$ and $3-$ $5 \mathrm{kbar}$ for Tiefengletscher, $460-530^{\circ} \mathrm{C}$ and $5-7 \mathrm{kbar}$ for Cavagnoli, and $530-600^{\circ} \mathrm{C}$ and $5-7 \mathrm{kbar}$ for Faido (Fig. 14).

As fluid inclusion microthermometry provides only minimum temperatures and P-T slopes (obtained from 


\begin{tabular}{|c|c|c|c|c|c|c|c|c|c|c|c|c|c|c|c|}
\hline $\begin{array}{l}\text { Mn } \\
(\mathrm{ppm})\end{array}$ & $\begin{array}{l}\mathrm{Cu} \\
(\mathrm{ppm})\end{array}$ & $\begin{array}{l}\text { Zn } \\
\text { (ppm) }\end{array}$ & $\begin{array}{l}\mathrm{Pb} \\
(\mathrm{ppm})\end{array}$ & $\begin{array}{l}\mathrm{Ag} \\
(\mathrm{ppm})\end{array}$ & $\begin{array}{l}\text { As } \\
\text { (ppm) }\end{array}$ & $\begin{array}{l}\text { Sb } \\
\text { (ppm) }\end{array}$ & $\begin{array}{l}\mathrm{Ti} \\
(\mathrm{ppm})\end{array}$ & $\begin{array}{l}\text { S } \\
(\mathrm{ppm})\end{array}$ & $\begin{array}{l}\mathrm{Cl} \\
(\mathrm{ppm})\end{array}$ & $\begin{array}{l}\mathrm{Br} \\
(\mathrm{ppm})\end{array}$ & $\begin{array}{l}\mathrm{Tm}_{\mathrm{CO}_{2}} \\
\left({ }^{\circ} \mathrm{C}\right)\end{array}$ & $\begin{array}{l}\mathrm{Tm}_{\text {ice }} \\
\left({ }^{\circ} \mathrm{C}\right)\end{array}$ & $\begin{array}{l}\mathrm{Tm}_{\mathrm{Cla}} \\
\left({ }^{\circ} \mathrm{C}\right)\end{array}$ & $\begin{array}{l}{ }^{\mathrm{Th}} \mathrm{CO}_{2} \\
\left({ }^{\circ} \mathrm{C}\right)\end{array}$ & $\begin{array}{l}\mathrm{Th}_{\text {tot }} \\
\left({ }^{\circ} \mathrm{C}\right)\end{array}$ \\
\hline & & 1.8 & 1.0 & & 290 & 9.5 & & 1260 & & 82 & -57.0 & & 9.9 & & \\
\hline & & 1.5 & 1.5 & 0.13 & 300 & 6.0 & & 1170 & & 110 & -57.0 & & 9.9 & 27.4 & 299 \\
\hline & 1.5 & & 0.78 & 0.36 & 230 & 5.0 & 4.8 & 1030 & 1480 & 19 & -57.0 & & 9.9 & 26.0 & \\
\hline & 3.4 & 1.7 & 0.59 & & 420 & 10 & 3.8 & 2950 & 600 & & -57.1 & & 9.8 & 27.4 & 303 \\
\hline & 0.9 & & 0.77 & 0.10 & 350 & 11 & 2.0 & 1880 & 520 & & -57.2 & & & & \\
\hline & 2.1 & & 1.5 & & 410 & 6.5 & & 1920 & & & -57.0 & & 9.9 & & \\
\hline & & & 0.27 & & 340 & 8.9 & & 1420 & & & -57.1 & & & & \\
\hline & 2.9 & 1.6 & 0.33 & & 200 & 5.2 & & 770 & & & -57.0 & & 9.9 & 25.9 & \\
\hline & 2.4 & & & & 350 & 14 & & 2940 & & & -57.0 & & 9.9 & & \\
\hline & & & & & 200 & 3.3 & & 800 & & & -57.1 & & 9.8 & 25.9 & \\
\hline & & & 0.85 & & 370 & 9.0 & & 1590 & & & -57.0 & & 9.9 & & \\
\hline 16 & 35 & 16 & 20 & 0.74 & 88 & 2.6 & 19 & 1180 & 11200 & 210 & -58.2 & & 9.3 & 26.2 & 300 \\
\hline \multirow[t]{2}{*}{34} & 100 & 30 & 40 & 1.5 & 140 & 1.8 & 8.1 & 2740 & 11600 & 260 & -58.2 & & 9.2 & 28.0 & 299 \\
\hline & 84 & 7.0 & 24 & & 1.0 & 0.5 & 1.9 & 190 & 13900 & 150 & -57.9 & & 9.3 & 28.3 & \\
\hline 2.1 & 4 & 4.5 & 33 & 0.09 & 91 & 3.0 & 33 & 1570 & 11300 & 350 & -58.0 & & 9.3 & 28.4 & \\
\hline 16 & 66 & 20 & 22 & 1.1 & 120 & 3.1 & 7.3 & 1660 & 10300 & 290 & -58.2 & & 9.2 & 29.2 & 294 \\
\hline 14 & 130 & 46 & 31 & 2.1 & 110 & 1.9 & 20 & 2050 & 12800 & 240 & -58.1 & & 9.2 & 26.5 & \\
\hline 3.2 & 210 & 49 & 43 & 2.7 & 160 & 1.5 & 6.0 & 4100 & 11300 & 120 & -58.2 & & 9.3 & & \\
\hline 61 & 150 & 43 & 67 & 2.7 & 200 & 3.3 & & 2930 & 13600 & 400 & -58.2 & & 9.3 & 26.2 & 302 \\
\hline 60 & 100 & 36 & 42 & 1.7 & 140 & 3.5 & 10 & 3380 & 8340 & 380 & -57.9 & & 9.2 & 28.7 & 307 \\
\hline 39 & 65 & 49 & 33 & 1.2 & 150 & 1.2 & & 2720 & 14100 & 250 & -58.2 & & 9.2 & 26.9 & \\
\hline \multirow[t]{2}{*}{66} & 150 & 52 & 49 & 2.3 & 160 & 3.4 & & 3290 & 9710 & 260 & -58.0 & & 9.3 & 26.8 & 313 \\
\hline & 1.6 & 5.8 & 7.0 & & 43 & 1.0 & 15 & 630 & 13400 & 290 & -58.1 & & 9.2 & & \\
\hline 23 & 7.0 & 5.8 & 5.0 & 1.1 & 130 & 3.0 & 3.4 & 1620 & 9790 & 400 & -58.2 & & 9.2 & & \\
\hline 21 & 14 & 14 & 9.0 & & 150 & 2.3 & 28 & 2080 & 13500 & 270 & -58.2 & & 9.3 & & \\
\hline 20 & 26 & 13 & 11 & & 98 & 1.8 & & 1300 & 13200 & 270 & -58.1 & & 9.2 & 29.1 & \\
\hline
\end{tabular}

isochores calculated from the fluid densities), additional independent temperature or pressure information is required for evaluating the conditions of fluid inclusion entrapment and vein formation. Commonly, geothermometry of vein and host-rock minerals is used to provide this temperature information, which is then combined with isochores calculated from fluid inclusion data (Goldstein \& Reynolds 1994; Bakker 2003). This approach relies on the presence of appropriate mineral assemblage that are suitable as geothermometers and requires that the relative timing of vein minerals can be unequivocally linked to that of fluid inclusion assemblages.

Alternatively, chemical solute thermometers that are routinely used for geothermometry of active thermal springs and geothermal systems (Arnorsson 2000) can be applied to fluid inclusion compositions (Mullis et al. 1994; Marsala et al. 2013; Miron et al. 2013). We have used the Na-K (Giggenbach 1988), Na-Li (Kharaka et al. 1982), Li-Mg (Kharaka \& Mariner 1989), K-Mg (Giggenbach 1988), Na-Mg (Giggenbach 1988), Na-KCa (Fournier \& Truesdell 1973), and Na-K-Mg (Nieva \& Nieva 1987) geothermometers. For most vein locations, the $\mathrm{Na}-\mathrm{K}$ and $\mathrm{Na}-\mathrm{Li}$ thermometers gave consistent results and a comparatively narrow range in temperatures (Table 6). The geothermometers relying on $\mathrm{Mg}$ and $\mathrm{Ca}$ concentrations yielded reasonable temperatures for some locations, but for other locations (Cavagnoli and Faido) gave results that were inconsistent with fluid inclusion homogenization and other temperature estimates. This is due to the high analytical uncertainties associated with the LA-ICPMS measurements of $\mathrm{Mg}$ and Ca. Solute geothermometry was not successful for the Cavagnoli data, because all geothermometers gave temperatures that were below the fluid inclusion homogenization temperatures or just overlapped with them. This reflects the low total elemental concentrations and related large analytical uncertainties for these very low salinity (0.4 wt.\% eqv. $\mathrm{NaCl}$ ) aqueous-carbonic fluid inclusions.

The estimates of Alpine fissure vein formation temperatures were therefore based on the $\mathrm{Na}-\mathrm{K}$ and $\mathrm{Na}-\mathrm{Li}$ solute thermometers (Table 6). For the Gauli, Gerstenegg, and Tiefengletscher veins, we accepted the total range in temperature obtained from both the $\mathrm{Na}-\mathrm{K}$ and $\mathrm{Na}-\mathrm{Li}$ thermometers. For the Cavagnoli and Faido veins, we discarded temperatures that were below the average value of the fluid inclusion homogenization temperatures (295 and $299^{\circ} \mathrm{C}$ for Cavagnoli and Faido) and accepted the range in temperature above $300^{\circ} \mathrm{C}$ from the $\mathrm{Na}-\mathrm{K}$ and $\mathrm{Na}-\mathrm{Li}$ thermometers. This resulted in estimates for the vein formation temperatures of $280-380^{\circ} \mathrm{C}$ for Gauli, $250-350^{\circ} \mathrm{C}$ for Gerstenegg, $350-440^{\circ} \mathrm{C}$ for 

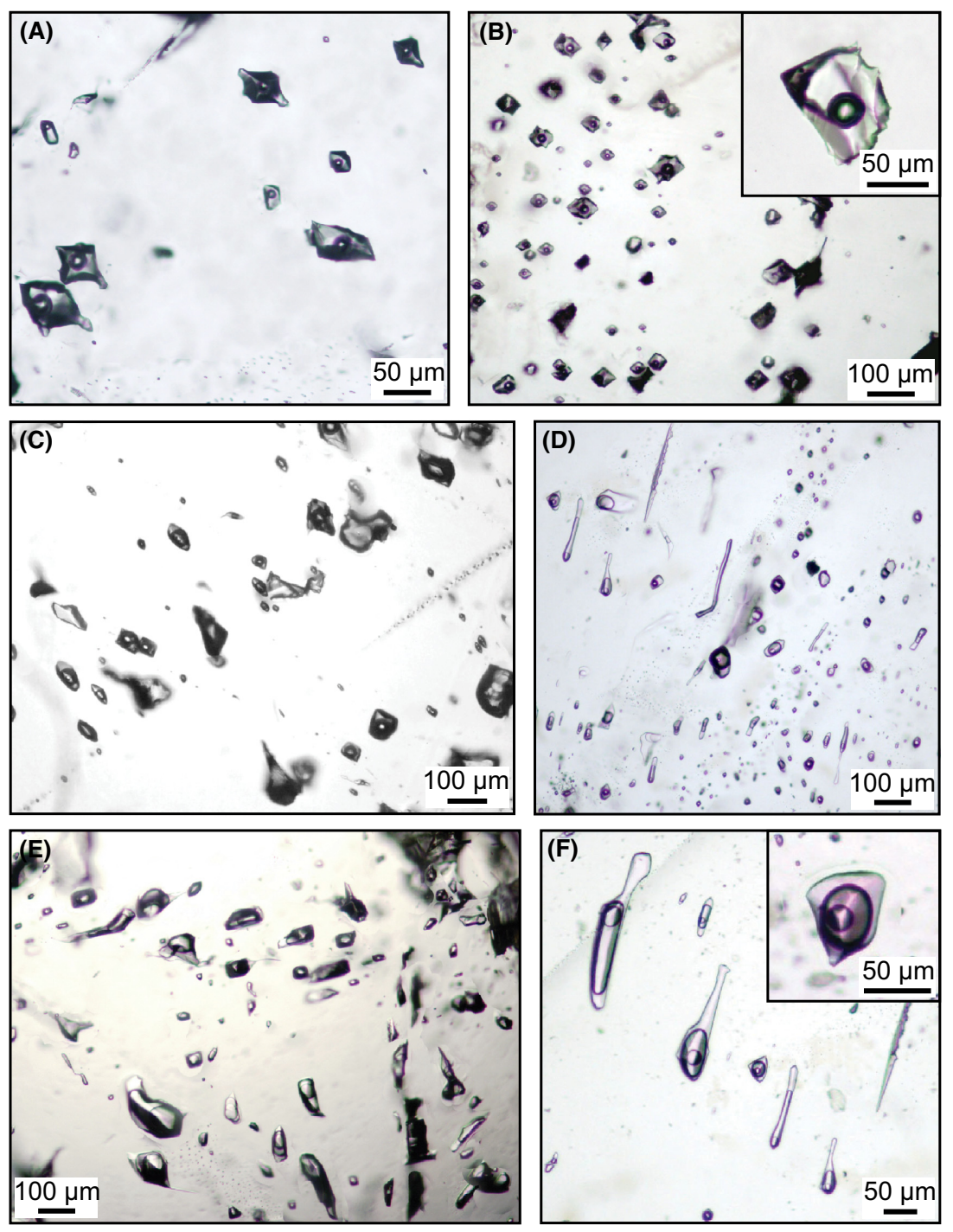

Fig. 6. Photographs of typical fluid inclusion assemblages (FIA). (A) Characteristic regularly shaped aqueous (LV) fluid inclusions from Vals (FIA A2). (B) Characteristic regularly shaped aqueous (LV) fluid inclusions from Tiefengletscher (FIA A4). (C) Trail of aqueous-carbonic (LLV) fluid inclusions from Faido (FIA B1). (D) Several subparallel trails of aqueous-carbonic (LLV) fluid inclusions from Cavagnoli. (E) Irregularly shaped aqueouscarbonic (LLV) fluid inclusions from Bedretto (FIA A2). (F) Trail of elongate aqueouscarbonic (LLV) fluid inclusions from Cavagnoli (FIA B3).

Tiefengletscher, $300-360^{\circ} \mathrm{C}$ for Cavagnoli, and $300-$ $360^{\circ} \mathrm{C}$ for Faido. Pressure estimates for each fissure vein were then obtained by combining the temperature ranges calculated by solute geothermometry with fluid inclusion isochores for the same FIA. This results in estimates for the vein formation pressures of 2.2-4.7 kbar for Gauli, 1.0-3.2 kbar for Gerstenegg, 2.1-4.1 kbar for Tiefengletscher, 1.4-3.0 kbar for Cavagnoli, and 1.5-3.1 kbar for Faido (Fig. 14).

Additional and potentially better P-T constraints can be obtained from the results of multicomponent fluid-mineral equilibria modeling (e.g., Spycher et al. 2014). We have modeled the fluid equilibrium speciation and rock composition (mineralogy and mineral abundance) over the temperature range $200-600^{\circ} \mathrm{C}$ and at the pressure that represents the average value of the range obtained from the fluid inclusion geothermobarometry (solute thermometers and isochores). Because exploratory fluid- mineral equilibria calculations have shown that the relevant mineral stability boundaries are not very sensitive to pressure, we performed calculations for fixed pressures (3.0 kbar for Gauli, $2.5 \mathrm{kbar}$ for Gerstenegg, $3.0 \mathrm{kbar}$ for Tiefengletscher, $1.8 \mathrm{kbar}$ for Cavagnoli, and $2.0 \mathrm{kbar}$ for Faido). The modeled wall-rock mineralogy and mineral abundance were compared to the minerals identified by petrography.

The complete mineral abundance and fluid composition results are plotted for two examples in Fig. 12 (Tiefengletscher and Faido), and Fig. 13 shows the predicted mineralogy as function of temperature for all five localities. The modeled element ratios in the fluid such as $\mathrm{K} / \mathrm{Na}, \mathrm{Ca} / \mathrm{Na}, \mathrm{Mg} / \mathrm{Na}$, and $\mathrm{Mg} / \mathrm{K}$ were compared to those determined by LA-ICPMS analysis of fluid inclusions (Fig. 12). The temperature range of overlap is used for estimating vein formation temperature (Fig. 14). We then combined these temperature 


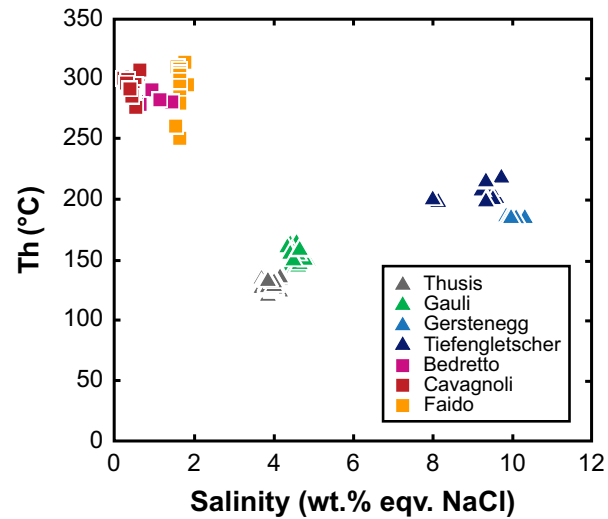

Fig. 7. Plot of salinity (wt.\% equivalent $\mathrm{NaCl}$ ) vs. total homogenization temperature $\left(\mathrm{Th}_{\mathrm{tot}}\right)$ for all locations. Each data point represents the average value for one fluid inclusion assemblage (FIA). Data for Thusis are from Miron et al. (2013). Standard deviations within one FI are slightly larger than the symbol size, showing that fluid properties at each location are constant across several stages of entrapment according to petrographic relations. The aqueous fluid inclusions show a broadly positive correlation between salinity and homogenization temperatures, whereas the aqueouscarbonic fluid inclusions do not show such a correlation.

ranges with the isochores for fluid inclusions from each Alpine fissure vein, to obtain our best estimates for the pressure-temperature conditions for fluid inclusion entrapment and Alpine vein formation, that is, $320-380^{\circ} \mathrm{C}$ and $2.8-4.6 \mathrm{kbar}$ for Gauli, $330-350^{\circ} \mathrm{C}$ and $2.2-3.2 \mathrm{kbar}$ for Gerstenegg, $350-430^{\circ} \mathrm{C}$ and 2.1-3.9 kbar for Tiefengletscher, $300-350^{\circ} \mathrm{C}$ and 1.4-2.9 kbar for Cavagnoli, and $300-340^{\circ} \mathrm{C}$ and 1.5-2.8 kbar for Faido.

\section{DISCUSSION AND CONCLUSIONS}

\section{Fluid sources}

The regional correlation of metamorphic grade with the major-component composition of fissure vein fluids indicates a fluid source related to prograde Alpine metamorphism (Mullis et al. 1994; Mullis 1996). On the other hand, the occurrence of the largest fissure veins in previously metamorphosed granites subject to retrograde greenschist-facies metamorphism during the Alpine orogeny (Gerstenegg and Tiefengletscher in the Aar massif) requires a fluid source outside of the local host rock. The detailed microthermometric and LA-ICPMS data from eight fissure veins reported here demonstrate that the fluid inclusions in Alpine fissure veins were trapped from compositionally variable, but locally exceptionally homogeneous fluids. Throughout the entire sequence of quartz crystal growth and fluid inclusion entrapment at each location, encompassing several generations of texturally pseudosecondary FI in different growth zones and later secondary FI on crosscutting healed fractures, essentially the same fluid has been present. The chemical geothermometry and the results of fluid-mineral equilibria modeling support the conclusion that wall-rock leaching, mineral precipitation in the fissure veins, and fluid inclusion entrapment proceeded under rock-buffered conditions that closely approached fluid-rock equilibrium at the scale of the local host rock unit. Therefore, the concentrations of most chemical components in the fluid (notably the major and minor cations that are dictated by fluid-mineral equilibria with rockforming minerals such as feldspars, micas, and ferromagnesian minerals) cannot inform us about the ultimate source of the fluids. The same evidence applies to oxygen isotope compositions of quartz crystals, which were previously shown to be completely buffered by quartz in the local host rock (Sharp et al. 2005). Chemical components that preferentially partition into the fluid phase, such as halogens, carbon, hydrogen, and possibly arsenic and boron have a better chance of preserving information about the ultimate fluid source (Ridley \& Diamond 2000).

The halogen elements, chlorine, bromine, and iodine, are among the most popular tracers for distal fluid sources, because their concentrations are several orders of magnitude higher in saline fluids $(2.03 \mathrm{wt} . \% \mathrm{Cl}$ and $69.7 \mathrm{ppm} \mathrm{Br}$ in seawater) than in crustal rocks (244 ppm Cl and $0.88 \mathrm{ppm} \mathrm{Br}$ for the average continental crust; Rudnick \& Gao 2004), and they are not easily incorporated into rock-forming minerals during fluidrock interaction and hydrothermal alteration (Banks et al. 1991; Heinrich et al. 1993; Yardley et al. 1993; Meere \& Banks 1997; McCaig et al. 2000). The $\mathrm{Cl} / \mathrm{Br}$ ratios of fluid inclusions have been used to discriminate between several principal fluid sources such as seawater (molar Cl/Br ratio: 640; McCaffrey et al. 1987), evaporated seawater $(\mathrm{Cl} / \mathrm{Br}$ ratio: lower than seawater $)$, and fluids that have dissolved halite $(\mathrm{Cl} / \mathrm{Br}$ ratio: higher than seawater) from evaporite sediments (Chi \& Savard 1997; Stober \& Bucher 1999; Yardley 2013).

Considering only our higher quality data obtained with the optimized element menu, the average molar $\mathrm{Cl} / \mathrm{Br}$ values of all analyzed Alpine fissure fluids are consistently below the seawater value of 640 . The fluids trapped in fissure veins of the Aar massif have moderately depleted $\mathrm{Cl} / \mathrm{Br}$ between 300 and 600, whereas values in the amphibolite-facies Penninic nappes are even lower between 50 and 200 (Fig. 9). Such data would be conventionally interpreted by involvement of evaporated seawater (residual bittterns), which may appear possible considering that evaporites form part of the upper crustal Alpine nappe stack (Berger et al. 2005; Wiederkehr et al. $2009,2011)$. However, the lowest $\mathrm{Cl} / \mathrm{Br}$ ratios would require extreme evaporation of seawater, by removal of 


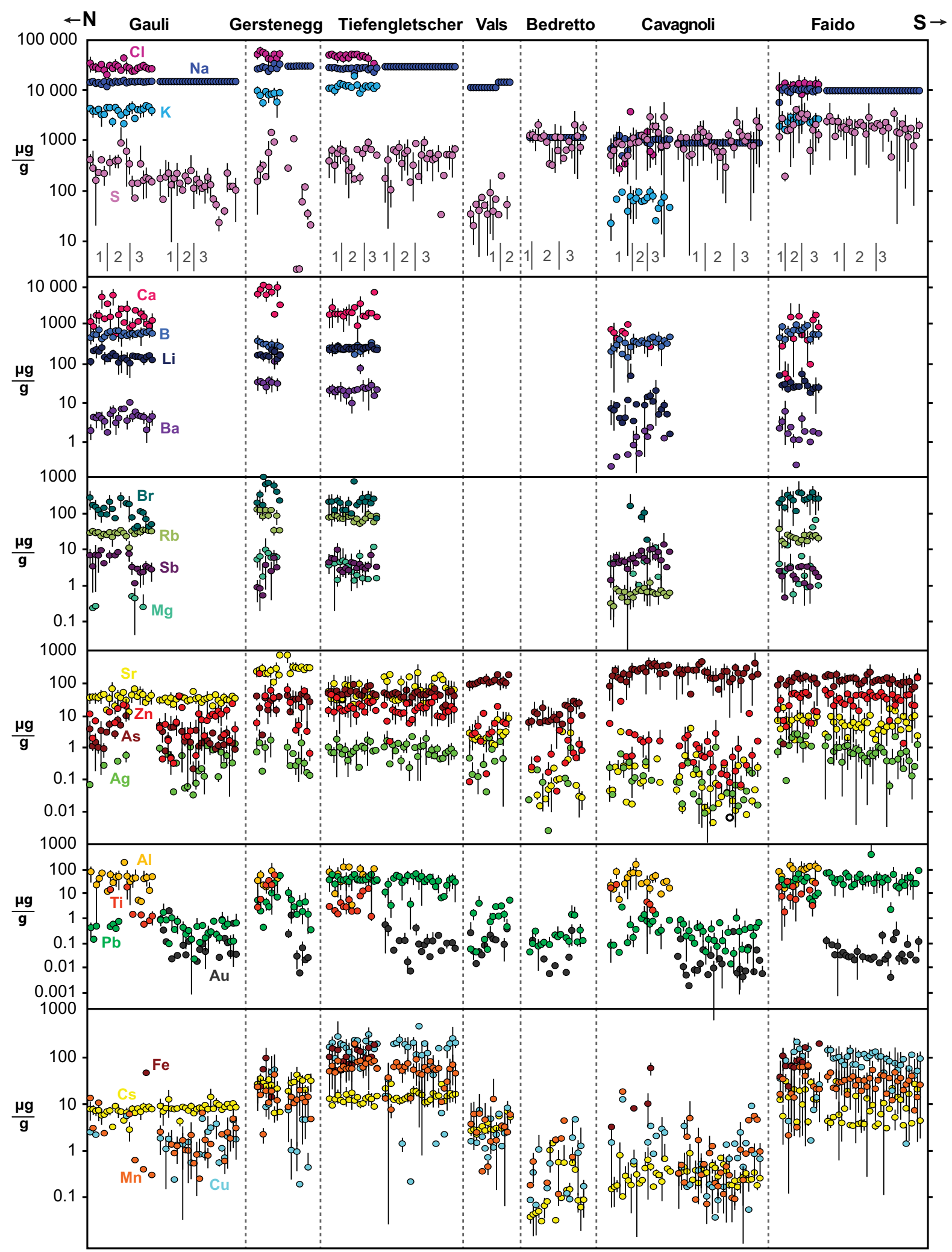

Fig. 8. Summary plot of the average composition of fluid inclusion assemblages analyzed by LA-ICPMS from all investigated Alpine fissure veins (error bars are $\pm 1 \sigma$ standard deviation within each FIA). Data for each locality are sorted according to relative age of fluid inclusion assemblages (1: earliest pseudosecondary FIA in the core of the quartz crystals; 2: younger FIA, either pseudosecondary FIA in late growth zones of quartz crystals or secondary FIA that crosscut through all growth zones; 3: texturally pseudosecondary or secondary FIA with ambiguous time relationships). 
Fig. 9. Summary diagram of the molar $\mathrm{Cl} / \mathrm{Br}$ ratios obtained from FIA from Gauli, Gerstenegg, Tiefengletscher, Bedretto, Cavagnoli, and Faido. All data points are assemblage averages with error bars of $\pm 1 \sigma$ standard deviation, no error bars indicate that only one inclusion was measured above the limits of detection for both $\mathrm{Br}$ and $\mathrm{Cl}$. Open symbols are data obtained with the multielement menu, while full symbols are data obtained with the shorter element menu optimized for halogen analysis (see Seo et al. 2011). The seawater value (640) is given for reference.

Fig. 10. Variation of (A) lithium, (B) rubidium, (C) boron, (D) potassium, (E) barium, and (F) copper concentrations as function of bulk fluid salinity (expressed as wt.\% equivalent $\mathrm{NaCl}$ ). The three alkali metals ( $\mathrm{Li}, \mathrm{Rb}$, and $\mathrm{K}$ ) and $\mathrm{Ba}$ show a positive correlation with salinity, whereas B concentrations are broadly negatively correlated with salinity.
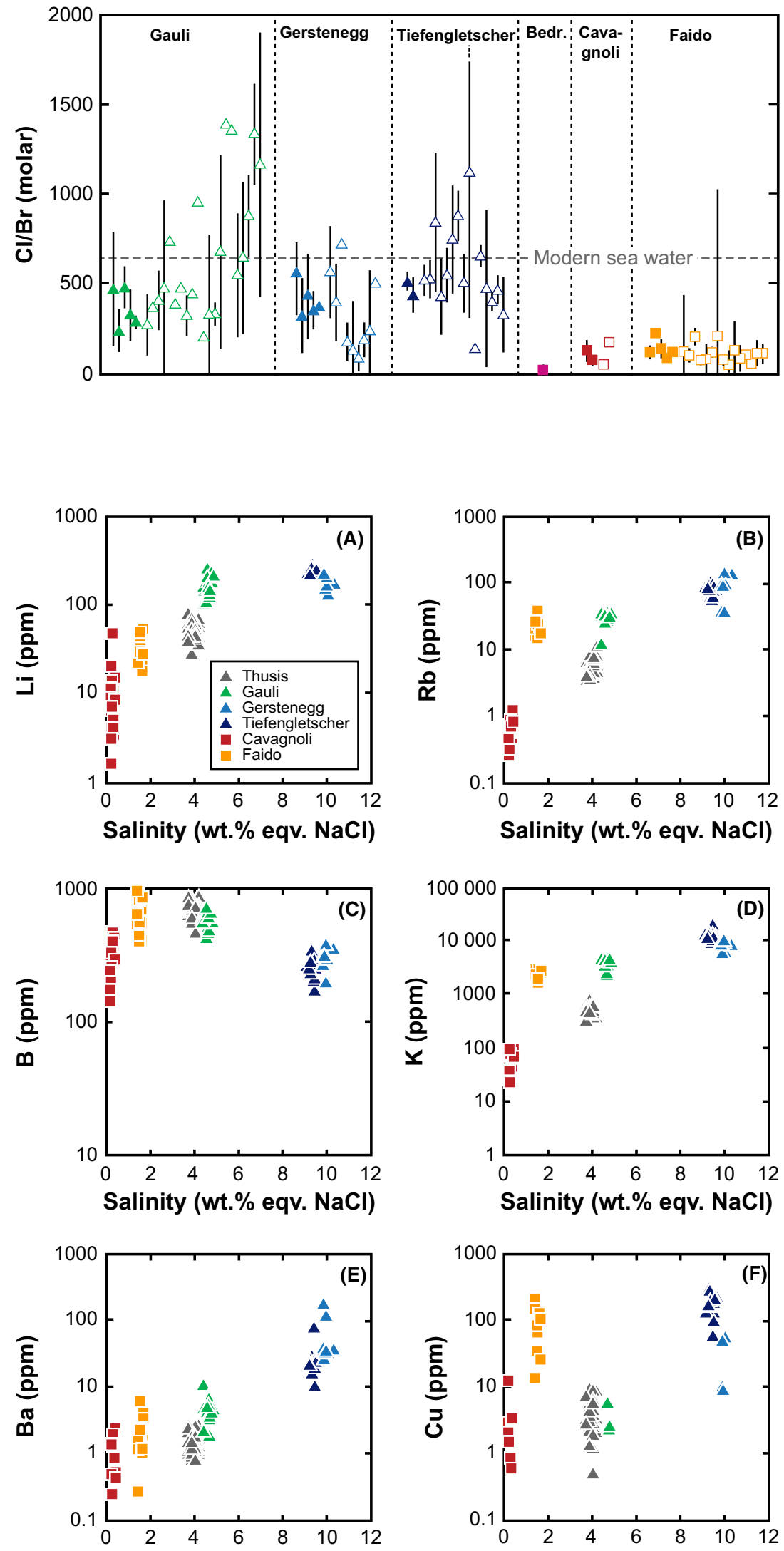

Salinity (wt.\% eqv. $\mathrm{NaCl}$ )

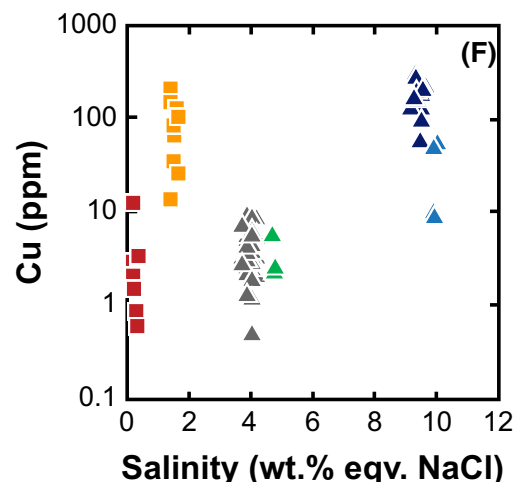



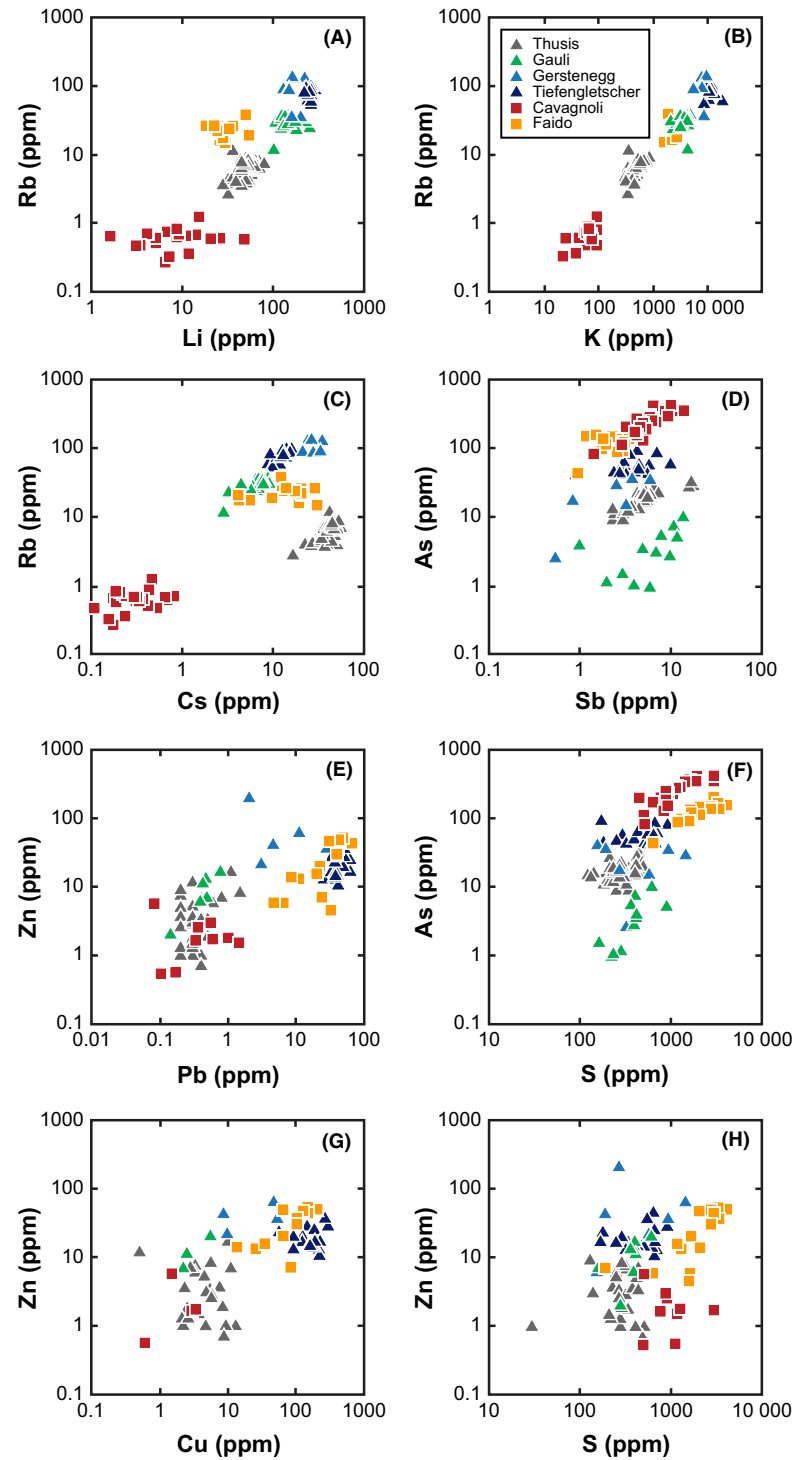

Fig. 11. Variation diagrams for fluid inclusion compositions, with each data point representing the average of one FIA. (A) Rb as function of $\mathrm{Li}$; (B) $\mathrm{Rb}$ as function of $\mathrm{K}$; (C) Rb as function of $\mathrm{Cs}$; (D) As as function of $\mathrm{Sb}$; (E) $\mathrm{Zn}$ as function of $\mathrm{Pb}$; (F) As as function of $\mathrm{S}$; (G) $\mathrm{Zn}$ as function of $\mathrm{Cu}$; $(\mathrm{H}) \mathrm{Zn}$ as function of $\mathrm{S}$. Squares are aqueous-carbonic and triangles are aqueous inclusions differentiated by colors according to localities.

$>90 \%$ of initial marine salts as halite, prior to renewed dilution with salt-free metamorphic water. Such mass balance considerations do not make this interpretation very plausible.

An alternative to explain low $\mathrm{Cl} / \mathrm{Br}$ ratios in low-salinity fluids is the interaction between metamorphic fluids and Br-enriched organic matter or graphite, which may contain high concentrations of $\mathrm{Br}$ (Kendrick et al. 2011). Reaction between salty fluids and organic matter can liberate $\mathrm{Br}$ and result in a progressive decrease in the $\mathrm{Cl} / \mathrm{Br}$ along the fluid flow path, leading to pore fluids with $\mathrm{Cl} / \mathrm{Br}$ ratios resembling those of residual
Table 5 Average elemental composition for the short element menu and the calculated $\mathrm{Cl} / \mathrm{Br}$ molar ratios for the measured fluid inclusion assemblages (FIAs).

\begin{tabular}{ccccccc}
\hline FIA & \# Fl & Na (ppm) & $\mathrm{Rb}(\mathrm{ppm})$ & $\mathrm{Cl}(\mathrm{ppm})$ & $\mathrm{Br}(\mathrm{ppm})$ & $\mathrm{Cl} / \mathrm{Br}$ (by wt) \\
\hline Gauli & & & & & & \\
C1 & 2 & 14570 & 13 & 16910 & 90 & 470 \\
C2 & 3 & 14570 & 10 & 17460 & 210 & 240 \\
C3 & 3 & 14570 & 25 & 21860 & 110 & 480 \\
C4 & 4 & 14570 & 31 & 21550 & 190 & 330 \\
C5 & 3 & 14570 & 29 & 23650 & 190 & 290 \\
Gerstenegg & & & & & \\
C1 & 2 & 28630 & 150 & 55130 & 230 & 580 \\
C2 & 2 & 28630 & 150 & 53380 & 470 & 260 \\
C3 & 4 & 28630 & 150 & 69190 & 460 & 460 \\
C4 & 3 & 28630 & 130 & 52760 & 300 & 450 \\
C5 & 2 & 28630 & 150 & 72110 & 430 & 380 \\
Tiefengletscher & & & & & \\
A1 & 3 & 27060 & 160 & 54100 & 230 & 540 \\
B1 & 3 & 27060 & 150 & 45630 & 220 & 480 \\
Cavagnoli & & & & & \\
A1 & 10 & 890 & 1.4 & 290 & 17 & 130 \\
A2 & 5 & 890 & 0.8 & 220 & 12 & 67 \\
Faido & & & & & & \\
B1 & 2 & 9840 & 18 & 16020 & 330 & 120 \\
B2 & 2 & 9840 & 38 & 15950 & 160 & 230 \\
B3 & 4 & 9840 & 40 & 15080 & 270 & 140 \\
B4 & 2 & 9840 & 49 & 15560 & 400 & 85 \\
B5 & 3 & 9840 & 35 & 13240 & 260 & 120 \\
Bedretto & 1 & 1150 & & 470 & 60 & 18 \\
\hline
\end{tabular}

The complete dataset is provided in the Data S1.

evaporite brines (Kendrick et al. 2011). The $\mathrm{Cl} / \mathrm{Br}$ ratios of fluid inclusions from quartz veins in very-lowgrade metasediments of the Rhenish massif (Variscan fold-and-thrust belt) are similarly below seawater ratio and were interpreted by interaction with abundant organic matter, in the absence of any evaporites in the shallow marine sequence of the Rhenish massif (Marsala et al. 2013). Given that some of our locations are hosted in organic-bearing calc-mica schists (Thusis, Bedretto), the $\mathrm{Cl} / \mathrm{Br}$ ratios of the fluid inclusions trapped in the Alpine fissure veins may be interpreted in the same way. The fluids in the Aar Massiv could have been initially produced by metamorphic devolatilization of an underlying wedge of Mesozoic to Oligocene sedimentary rocks, which are locally rich in organic matter and were partly overthrusted during the last phases of Alpine subduction and incipient topographic uplift of the Aar massif (Schmid et al. 2004). Preferential retention of $\mathrm{Br}$ relative to $\mathrm{Cl}$ in organic-rich metasediments could also explain the observation that fluids with the lowest salinity but greatest relative enrichment in $\mathrm{Br}$ occur in fissure veins hosted by rocks of the highest metamorphic grade, in fluids where also the more refractory volatile components, $\mathrm{CO}_{2}$ and $\mathrm{H}_{2} \mathrm{~S}$, are enriched.

The measured sulfur concentrations vary over a large range from $10-20 \mathrm{ppm}$ up to $2000 \mathrm{ppm}$. Sulfur is 
Table 6 Summary of the results of solute geothermometry of fluid inclusions, based on LA-ICPMS data. Listed are average values and standard deviations for each solute geothermometer.

\begin{tabular}{|c|c|c|c|c|c|c|c|}
\hline Locality & $\mathrm{Na}-\mathrm{K}\left({ }^{\circ} \mathrm{C}\right) *$ & $\mathrm{Na}-\mathrm{Li}\left({ }^{\circ} \mathrm{C}\right)^{\dagger}$ & $\mathrm{Li}-\mathrm{Mg}\left({ }^{\circ} \mathrm{C}\right)^{*}$ & $\mathrm{~K}-\mathrm{Mg}\left({ }^{\circ} \mathrm{C}\right)^{*}$ & $\mathrm{Na}-\mathrm{Mg}\left({ }^{\circ} \mathrm{C}\right)^{*}$ & $\mathrm{Na}-\mathrm{K}-\mathrm{Ca}\left({ }^{\circ} \mathrm{C}\right)^{\S}$ & $\mathrm{Na}-\mathrm{K}-\mathrm{Mg}\left({ }^{\circ} \mathrm{C}\right)^{\oplus}$ \\
\hline Gauli & $312(23)$ & $319(57)$ & 446 (126) & 446 (129) & $573(250)$ & $300(21)$ & 329 (39) \\
\hline Gerstenegg & $321(30)$ & $254(13)$ & $333(21)$ & 359 (15) & 421 (87) & $305(21)$ & 307 (13) \\
\hline Tiefengletscher & $390(37)$ & $431(11)$ & $390(34)$ & $423(40)$ & 497 (97) & $364(23)$ & $354(25)$ \\
\hline Cavagnoli & 178 (33) & $300(65)$ & 196 (33) & $133(30)$ & $58(29)$ & $108(34)$ & $157(28)$ \\
\hline Faido & 307 (25) & 329 (33) & $242(38)$ & $297(46)$ & $275(108)$ & $301(16)$ & $279(21)$ \\
\hline
\end{tabular}

${ }^{*}$ Giggenbach (1988). ${ }^{\dagger}$ Kharaka et al. (1982). ${ }^{\ddagger}$ Kharaka \& Mariner (1989). ${ }^{\S}$ Fournier \& Truesdell (1973). ${ }^{\text {9 } N i e v a ~ \& ~ N i e v a ~(1987) . ~}$

Fig. 12. Comparison between results of fluid-mineral equilibria modeling and analytical data (fluid composition, mineral abundance). Diagrams (A) and (C) show the major element ratios $(\mathrm{K} / \mathrm{Na}, \mathrm{Ca} / \mathrm{Na}, \mathrm{S} / \mathrm{Na}$, $\mathrm{Mg} / \mathrm{K}$ and $\mathrm{Mg} / \mathrm{Na}$ ) in the fluid. Dotted lines are calculated element ratios as function of temperature, whereas symbols with error bars are measured values from fluid inclusions (average value for all FIA from one locality). The pressure-temperature conditions for Alpine vein formation were estimated from chemical solute thermometry and fluid inclusion isochores (see text). Diagrams (B) and (D) show predicted mineral abundance as function of temperature, which are in agreement with the mineralogy of the altered host rock in immediate vein contact at the estimated vein formation temperature.
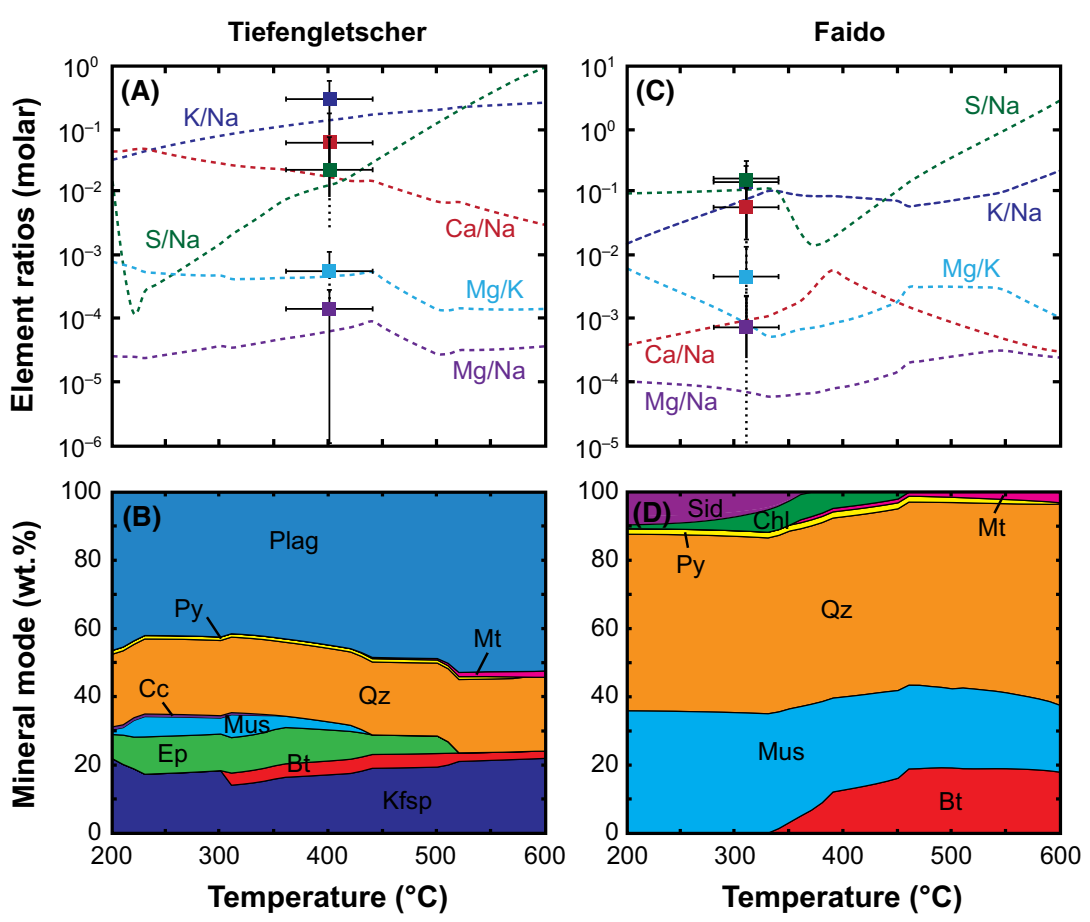

consistently higher in the aqueous-carbonic fluids hosted in amphibolite-facies rocks, compared to the aqueous fluid inclusions in greeschist-facies host rocks. This correlation supports the interpretation that sulfur in the fluid inclusions is produced by prograde metamorphic devolatilization of sulfide-bearing metasediments. Sulfur in metamorphic fluids has been previously reported from Raman spectroscopic studies of fluid inclusions (Dubessy et al. 1983) and is thought to be mainly the product of the prograde breakdown of pyrite to pyrrhotite. The metamorphic pyrite to pyrrhotite reaction broadly coincides with the production of water through breakdown of chlorite in mafic sequences near the greenschist-amphibolitefacies transition and the onset of decarbonation reactions in mixed calcite-sheet silicate rocks (Trommsdorff 1966; Powell et al. 1991; Craig \& Vokes 1993; Phillips \& Powell 1993, 2010; Tomkins 2010). The pyrite breakdown reaction has been investigated in graphitic metasedimentary rocks (Frey et al. 1980; Ferry 1981; Mohr \& Newton 1983; Hall 1986) and metamorphosed massive sulfide deposits (Craig \& Vokes 1993; Rosenberg et al. 2000; Tomkins 2007). The main conclusion of these studies is that the pyrite breakdown is not strictly an isograd reaction, because it depends not only on the P-T conditions, but also on the bulk composition and oxidation state of the rocks and fluid-mineral mass balance (Hall 1986; Tomkins 2007). This explains why the sulfur concentrations in fluid inclusions of the Alpine fissure veins show only a broad correlation with the metamorphic grade and considerable variation in lithologically different host-rock units that have experienced similar peak metamorphic conditions.

\section{Controls on minor element concentrations in metamorphic fluids}

The concentrations of the major rock-forming elements in the fluids that formed the Alpine fissure veins are largely controlled by mineral solubility and fluid-mineral equilibria, as demonstrated by the good agreement 

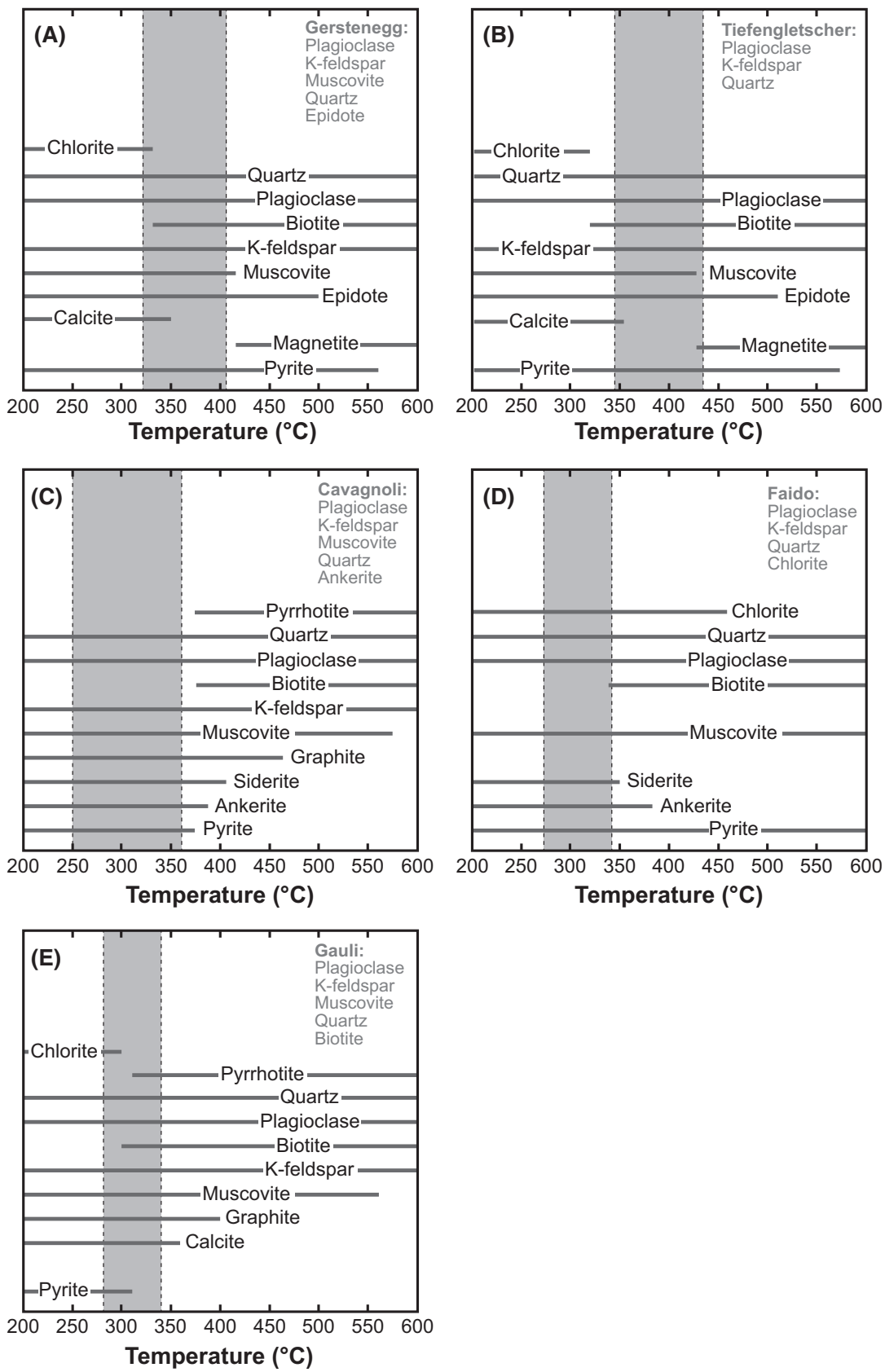

between modeled and analyzed concentrations. For minor elements such as the ore metals, concentrations in the fluid may be limited by availability in the source rocks, or in host rocks with which the fluids have interacted. Limited availability has been shown for the case of gold, where measured concentrations are lower by one to three orders of magnitude compared to those predicted from solubility calculations (Rauchenstein-Martinek et al. 2014). Neither the thermodynamic data for all aqueous species nor the solubility-controlling phases of many trace metals that were analyzed in the fluid inclusions (e.g., Li, $\mathrm{Rb}, \mathrm{Cs}, \mathrm{Sr}, \mathrm{Ba}, \mathrm{As}$, and $\mathrm{Sb}$ ) are accurately known.
Fig. 13. Diagrams illustrating the predicted host-rock mineralogy as function of temperature, compared to the observed mineral assemblage (list of minerals in the upper right corner of each diagram). The gray fields highlight the temperature range where the modeled mineralogy and mineral composition are in best agreement with the petrographically observed mineralogy. The mineralogy is shown for (A) Gerstenegg, (B) Tiefengletscher, (C) Cavagnoli, (D) Faido, and (E) Gauli.
Therefore, rigorous modeling of their solubility and quantitative analysis of their saturation state cannot be performed at present.

The concentrations of the alkali and alkaline earth metals correlate positively with the salinity (Figs 10 and 11). The fluids found in fissure veins from the Aar massif (Gauli, Gerstenegg, Tiefengletscher) have much higher salinity (up to $10.2 \mathrm{wt} . \%$ ), which is reflected by much higher concentrations of $\mathrm{Na}, \mathrm{K}, \mathrm{Li}, \mathrm{Rb}, \mathrm{Cs}, \mathrm{Ca}, \mathrm{Sr}$, and Ba compared with the lower-salinity fluids in the Penninic nappes. This trend reflects that alkali and alkaline earth metals are dominantly complexed by chloride 

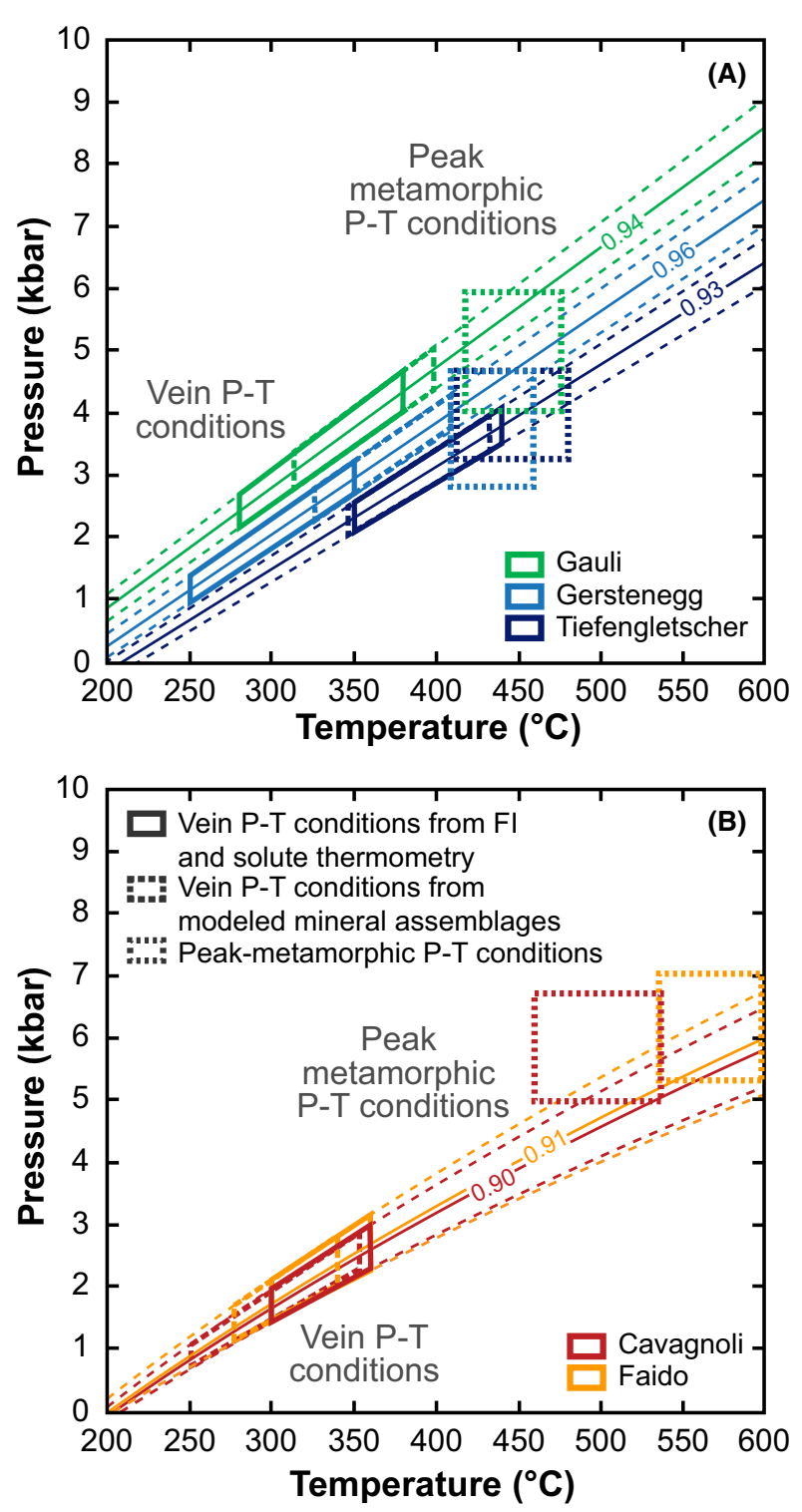

Fig. 14. Diagrams summarizing the estimated pressure-temperature conditions of Alpine fissure vein formation and peak metamorphic conditions of their respective host rocks. The peak metamorphic P-T conditions were adopted from Todd \& Engi (1997). The P-T conditions of vein formation were estimated from solute geothermometry, the temperature range of best agreement between modeled and observed mineral assemblages, and fluid inclusion isochores (solid lines: isochores for average fluid density; dashed lines: fluid inclusion isochores for minimum and maximum density based on standard deviations of micothermometric data; numbers on isochores: densities in $\mathrm{g} \mathrm{cm}^{-3}$ ). (A) Summary of pressure-temperature conditions for fissure veins with aqueous (LV) fluid inclusions (Gauli, Gerstenegg, Tiefengletscher). (B) Summary of pressure-temperature conditions for Alpine fissure veins with aqueous-carbonic (LLV) fluid inclusions (Cavagnoli, Faido).

species and that chloride complexes become more stable with increasing temperature (Wood \& Samson 1998; Yardley 2005).
Many of the divalent metals such as $\mathrm{Fe}, \mathrm{Mn}, \mathrm{Cu}, \mathrm{Zn}$, and $\mathrm{Pb}$ are also dominantly complexed by chloride species (Wood \& Samson 1998; Yardley 2005), although the importance of carbonate complexes of $\mathrm{Mn}$ and $\mathrm{Fe}$ is not fully understood and may be important in aqueouscarbonic fluids (Wolfram \& Krupp 1996). Manganese was analyzed in fluid inclusions from all localities and shows a fair correlation with salinity, in agreement with chloride complexation controlling Mn solubility (Suleimenov \& Seward 2000; Tian et al. 2014). Because of poor elemental detection limits, $\mathrm{Fe}$ concentrations are limited to the data from Tiefengletscher (Aar massif) and few data from the other localities. The concentrations of $\mathrm{Cu}$ and $\mathrm{Pb}$ are positively correlated with those of $\mathrm{Zn}$ for the entire dataset (Fig. 11E, G). Solubility control by fluidmineral equilibria involving $\mathrm{Zn}$ and $\mathrm{Pb}$ sulfides has been used to explain the clear correlation between the $\mathrm{Pb}$ and $\mathrm{Zn}$ concentrations in different crustal fluids, and the positive correlations between the concentrations of both metals, salinity, and temperature (Yardley 2005). The observation that the ore metals $\mathrm{Cu}, \mathrm{Zn}, \mathrm{Pb}$, and $\mathrm{Ag}$ have higher concentrations in samples from Tiefengletscher and Faido, compared to Alpine fissure veins that have experienced otherwise identical pressure-temperature conditions, requires an additional explanation. We suggest that host-rock mineralogy, for example the presence or absence of sulfides, may have exerted some control on the base metal concentrations of the fluids in the fissure veins.

Aluminum and titanium behave differently compared with the alkali, alkaline earth and the other divalent metals. The high $\mathrm{Al}$ and also $\mathrm{Ti}$ concentrations were somewhat unexpected, but the presence of $\mathrm{Al}$ minerals (large adularia, albite, and/or muscovite crystals) and Ti minerals (titanite, rutile) in the fissure vein assemblages confirms the mobility of both elements during fluid-rock interaction. The $\mathrm{Al}$ concentrations in the fluid inclusions do not correlate with the salinity, but they show a broadly positive correlation with temperature. Measured Al concentrations of 45-89 ppm exceed the predictions from experimental solubility studies and fluid-mineral equilibria modeling (Ragnarsdottir \& Walther 1985; Manning 1998, 2006, 2007; Tagirov \& Schott 2001; Verlaguet et al. 2006; Dolejs \& Wagner 2008) by an order of magnitude (Fig. 15). However, comparable $\mathrm{Al}$ concentrations in the range of tens of ppm up to more than $100 \mathrm{ppm}$ were previously analyzed in fluid inclusions from orogenic gold quartz veins in the western Alps (Yardley et al. 1993), in fluid inclusions from latemetamorphic quartz veins in the Rhenish massif (Marsala et al. 2013) and in fluid inclusions from fissure veins hosted by very-low-grade metasediments of the Bündnerschiefer in the Swiss Alps (Miron et al. 2013). The solubility and transport of $\mathrm{Al}$ in crustal fluids is thought to 

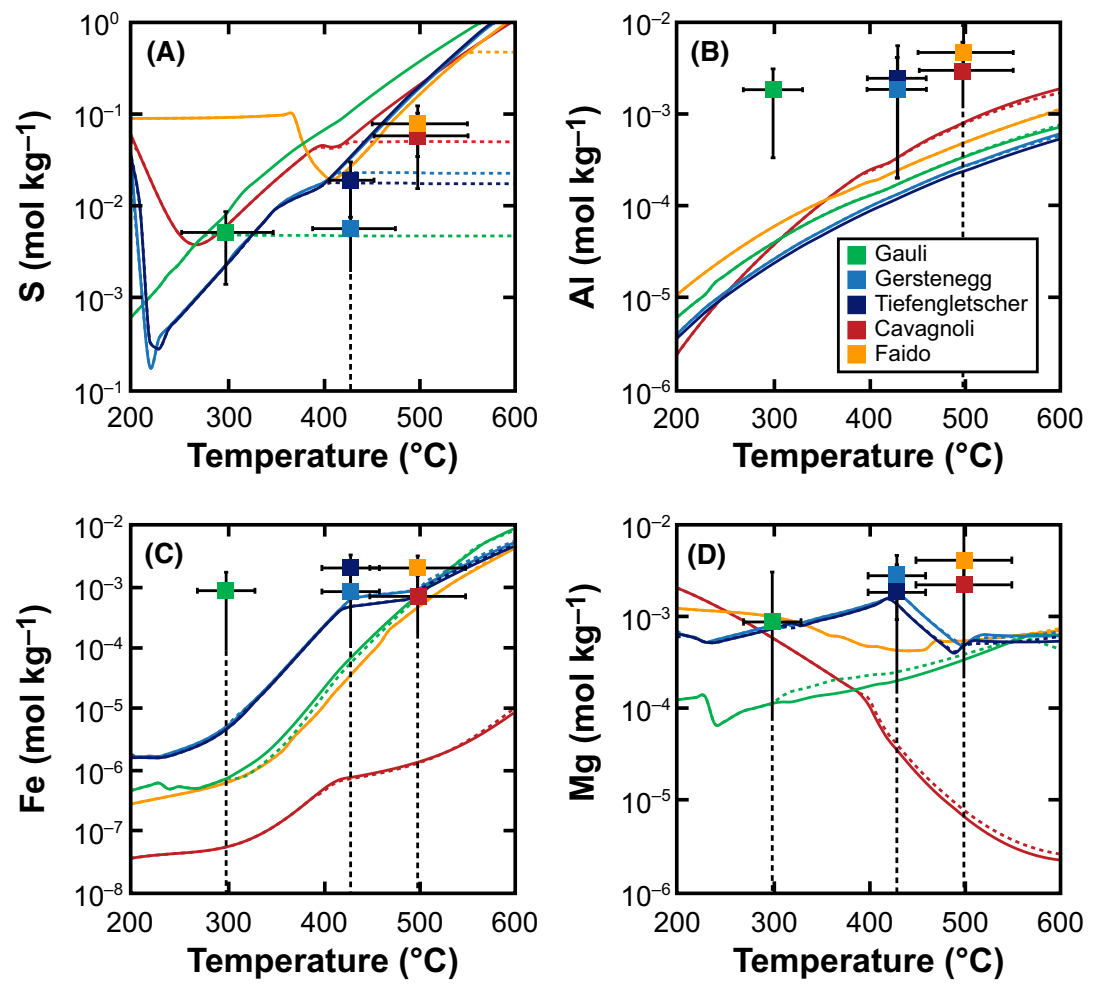

Fig. 15. Comparison between measured (symbols with error bars) and calculated (lines) element concentrations in fluid inclusions from Alpine fissure veins (Gauli, Gerstenegg, Tiefengletscher, Cavagnoli, and Faido). The lines are predicted concentrations as function of temperature. Solid lines represent element solubility calculated by assuming pyrite excess in the rock, while dashed lines were calculated based on measured sulfide concentration in the rock and in the fluid inclusions. The modeling results are in reasonable agreement with the measured fluid inclusion compositions for (A) sulfur, (C) iron, and (D) magnesium, whereas the measured (B) aluminum concentrations are systematically higher than the calculated solubility. be mainly controlled by $\mathrm{Al}$ hydroxy species, whereas complexation with chloride is not considered relevant (Tagirov \& Schott 2001). Experimental evidence shows that the $\mathrm{Al}$ solubility can be greatly enhanced by one to several orders of magnitude due to the presence of additional ligands such as fluorine, boron, and silica that form stable complexes with $\mathrm{Al}$ and that these complexes become more stable at elevated temperatures and pressures (Salvi et al. 1998; Tagirov et al. 2002a,b, 2004; Manning 2007). Elevated Al concentrations that were found in fluid inclusions from the orogenic gold quartz veins in the southern Alps were related to the formation of stable Al-fluoride complexes (Yardley et al. 1993). Fluorine cannot be analyzed by LA-ICPMS and we can therefore not test the effect of fluorine on $\mathrm{Al}$ solubility. We tentatively explain the high measured Al concentrations in the fluid inclusions by the combined solubility enhancing effect of $\mathrm{Al}$ complexing with fluorine, boron and silica.

\section{Geodynamic framework of Alpine fissure vein formation}

Combination of fluid inclusion chemistry, pressure-temperature conditions of vein formation, results from the fluid-mineral equilibria modeling, and published data for peak metamorphic conditions define local segments of the regional pressure-temperature paths of the central Alpine metamorphic dome, as summarized in
Fig. 16. Fluid pressures were probably close to the lithostatic load during fissure vein formation, as indicated by structural observations: (1) protracted crystallization of large crystals showing subtle fracturing and overgrowth, but never any collapse and vein re-opening; (2) the mechanical stability of large subhorizontal fissures (Fig. 2A); and (3) the persistence of open enechelon cavities even in weak host rocks undergoing concurrent ductile deformation (Miron et al. 2013). Given the surprisingly constant density and composition of the fluids, despite an apparently protracted dynamic evolution of the fissures, we envision an environment of slow drainage of deeper-sourced metamorphic fluids through a poorly connected fracture network, consistent with the localized occurrence of individual cavities along broadly defined corridors.

Assuming that the fissure veins formed under lithostatic fluid pressure, and taking an average rock density of $2.7 \mathrm{~g} \mathrm{~cm}^{-3}$, the pressure estimates for the Alpine fissure veins translate into formation depths of $10-17 \mathrm{~km}$ depth for Gauli, 8-12 km for Gerstenegg, 8-14 km for Tiefengletscher, $5-11 \mathrm{~km}$ for Cavagnoli and $6-10 \mathrm{~km}$ for Faido. Figure 16 shows that the fissures formed at similar temperatures between 300 and $430^{\circ} \mathrm{C}$. For the locations in the Aar massif, these temperature-depth estimates are broadly consistent with a long-term geothermal gradient of $25^{\circ} \mathrm{C} \mathrm{km}^{-1}$ indicated by zircon fission-track thermochronology (Glotzbach et al. 2010) 


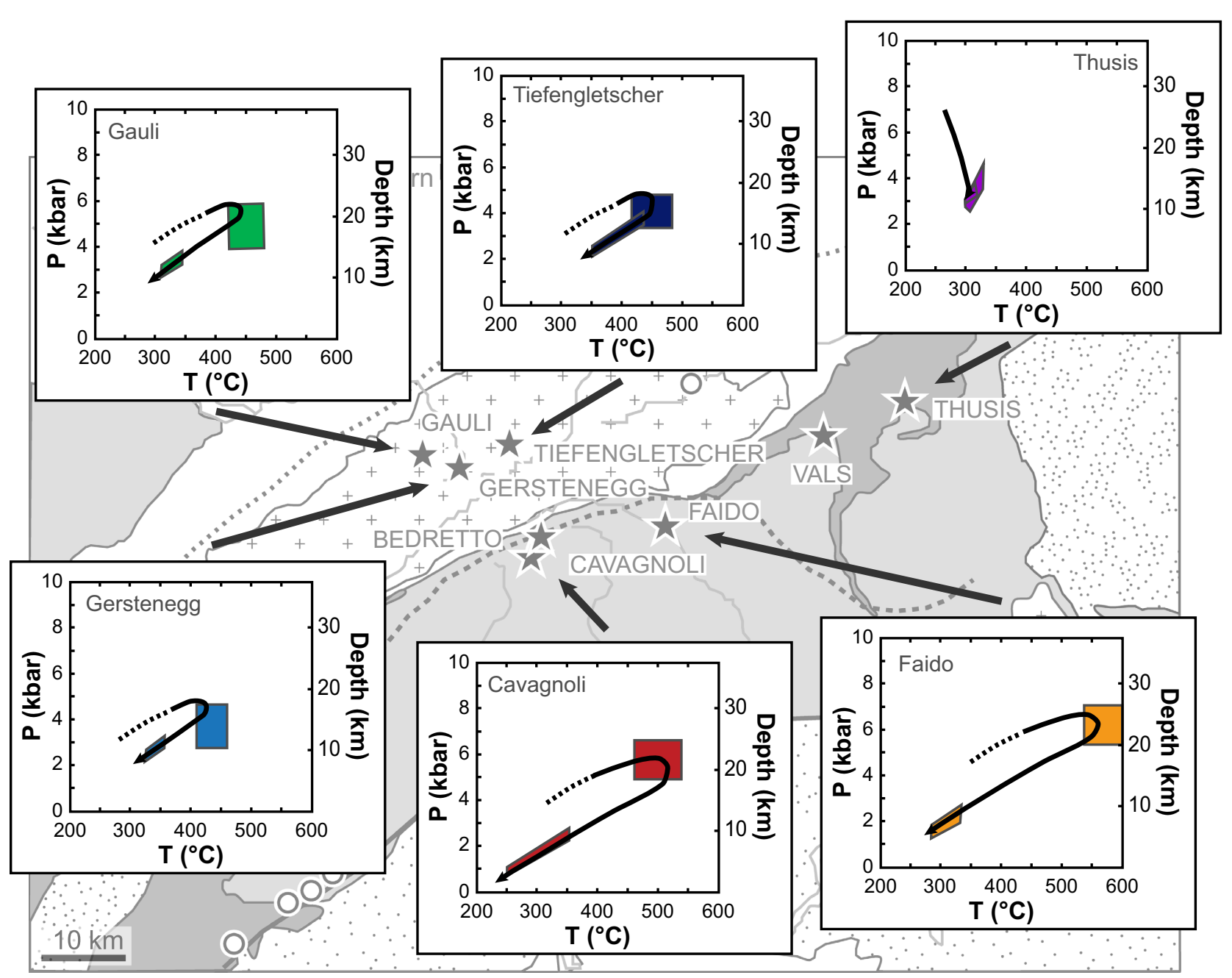

Fig. 16. Geological sketch map of the Central Alps, with superposed pressure-temperature diagrams illustrating the evolution of the fissure veins and their respective host rocks. Colored fields indicate conditions of peak metamorphism and subsequent fissure vein formation, whereas black arrows are interpreted P-T paths. The peak metamorphic pressure-temperature conditions were adopted from Todd \& Engi (1997).

and with the small difference between vein-forming and peak metamorphic conditions. For the locations further south, however, deviations between vein-forming conditions and peak metamorphic conditions systematically increase. Apparently, the shallowest veins formed in the southern areas, where peak metamorphic temperatures were highest, that is fissure vein formation is most distinctly retrograde with regard to the local metamorphic $\mathrm{P}-\mathrm{T}$ path. We cannot exclude postentrapment stretching of the fluid inclusions leading to an underestimation of vein formation pressure, but similar temperatures at shallower depth might be explained by rapid asymmetric uplift of the Lepontine dome after peak metamorphism, centered to the south of our study area (Fig. 1). Fissure veins formed when each location cooled toward the brittle-ductile transition of quartzrich host rocks, slowly draining fluids from local and subjacent metamorphic rocks as a result of uplift, but prior to erosion and interconnected permeability allowing incursion of meteoric water into texturally distinct epithermal veins (Sharp et al. 2005; Diamond \& Tarantola 2015).

\section{ACKNOWLEDGEMENTS}

This project was funded by the Swiss National Science Foundation (SNF), project No. 200021-130201. We thank A. Willener (KWO) for providing access to the Gerstenegg Alpine fissure vein. T. Good is thanked for preparation of petrographic and fluid inclusion sections and Lydia Zehnder for the XRF analyses of whole-rock samples. The Canton of Ticino (Dipartimento del Territorio and Museo Cantonale di Storia Naturale) is acknowledged for permission of sampling and provision of material from 
the Faido tunnel. We are grateful for interesting discussion with Josef Mullis, Larryn Diamond, and Bruce Yardley, and we thank two anonymous Geofluids reviewers for their constructive comments, which helped to improve this manuscript.

\section{REFERENCES}

Agard P, Goffé B, Touret JLR, Vidal O (2000) Retrograde mineral and fluid evolution in high-pressure metapelites (Schistes lustrés unit, Western Alps). Contributions to Mineralogy and Petrology, 140, 296-315.

Allan MM, Yardley BWD, Forbes LJ, Shmulovich KI, Banks DA, Shepherd TJ (2005) Validation of LA-ICP-MS fluid inclusion analysis with synthetic fluid inclusions. American Mineralogist, 90, 1767-75.

Arnorsson S (2000) Isotopic and Chemical Techniques in Geothermal Exploration, Development and Use: Sampling Methods, Data Handling, Interpretation. International Atomic Energy Agency, Vienna.

Audétat A, Günther D, Heinrich CA (2000) Magmatichydrothermal evolution in a fractionating granite: a microchemical study of the Sn-W-F-mineralized Mole Granite (Australia). Geochimica et Cosmochimica Acta, 64, 3373-93.

Bakker RJ (2003) Package FLUIDS 1. Computer programs for analysis of fluid inclusion data and for modelling bulk fluid properties. Chemical Geology, 194, 3-23.

Banks DA, Davies GR, Yardley BWD, McCaig AM, Grant NT (1991) The chemistry of brines from an Alpine thrust system in the central Pyrenees - an application of fluid inclusion analysis to the study of fluid behavior in orogenesis. Geochimica et Cosmochimica Acta, 55, 1021-30.

Baumgartner LP, Ferry JM (1991) A model for coupled fluid-flow and mixed-volatile mineral reactions with applications to regional metamorphism. Contributions to Mineralogy and Petrology, 106, 273-85.

Berger A, Mercolli I, Engi M (2005) The central Lepontine Alps: notes accompanying the tectonic and petrographic map sheet Sopra Ceneri (1:100’000). Schweizerische Mineralogische und Petrographische Mitteilungen, 85, 109-46.

Berger A, Rosenberg C, Schaltegger U (2009) Stability and isotopic dating of monazite and allanite in patially molten rocks: example from the Central Alps. Swiss Journal of Geosciences, $102,15-29$.

Berger A, Schmid SM, Engi M, Bousquet R, Wiederkehr M (2011) Mechanisms of mass and heat transport during Barrovian metamorphism: a discussion based on field evidence from the Central Alps (Switzerland/northern Italy). Tectonics, 30, TC1007.

Bickle MJ, Mckenzie D (1987) The transport of heat and matter by fluids during metamorphism. Contributions to Mineralogy and Petrology, 95, 384-92.

Bodnar RJ (1993) Revised equation and table for determining the freezing-point depression of $\mathrm{H}_{2} \mathrm{O}-\mathrm{NaCl}$ solutions. Geochimica et Cosmochimica Acta, 57, 683-4.

Boiron MC, Cathelineau M, Banks DA, Fourcade S, Vallance J (2003) Mixing of metamorphic and surficial fluids during the uplift of the Hercynian upper crust: consequences for gold deposition. Chemical Geology, 194, 119-41.

Bousquet R, Oberhänsli R, Goffe B, Jolivet L, Vidal O (1998) High-pressure-low-temperature metamorphism and deformation in the Bündnerschiefer of the Engadine window: implications for the regional evolution of the eastern Central Alps. Journal of Metamorphic Geology, 16, 657-74.

Burke EAJ (2001) Raman microspectrometry of fluid inclusions. Lithos, 55, 139-58.

Burkhard M, Kerrich R (1988) Fluid regimes in the deformation of the Helvetic nappes, Switzerland, as inferred from stable isotope data. Contributions to Mineralogy and Petrology, 99, 416-29.

Burrus RC (1981) Analysis of phase equilibria in C-O-H-S fluid inclusions. Mineralogical Association of Canada Short Course Series, 6, 39-74.

Cartwright I, Buick IS (2000) Fluid generation, vein formation and the degree of fluid-rock interaction during decompression of high-pressure terranes: the Schistes Lustres, Alpine Corsica, France. Journal of Metamorphic Geology, 18, 607-24.

Chi GX, Savard MM (1997) Sources of basinal and Mississippi Valley-type mineralizing brines: mixing of evaporated seawater and halite-dissolution brine. Chemical Geology, 143, 121-5.

Coggon R, Holland TJB (2002) Mixing properties of phengitic micas and revised garnet-phengite thermobarometers. Journal of Metamorphic Geology, 20, 683-96.

Connolly JAD, Thompson AB (1989) Fluid and enthalpy production during regional metamorphism. Contributions to Mineralogy and Petrology, 102, 347-66.

Craig JR, Vokes FM (1993) The metamorphism of pyrite and pyritic ores - an overview. Mineralogical Magazine, 57, 3-18.

Dale J, Powell R, White RW, Elmer FL, Holland TJB (2005) A thermodynamic model for Ca-Na clinoamphiboles in $\mathrm{Na}_{2} \mathrm{O}$ $\mathrm{CaO}-\mathrm{FeO}-\mathrm{MgO}-\mathrm{Al}_{2} \mathrm{O}_{3}-\mathrm{SiO}_{2}-\mathrm{H}_{2} \mathrm{O}-\mathrm{O}$ for petrological calculations. Journal of Metamorphic Geology, 23, 771-91.

Demartin F, Gramaccioli CM, Pilati T (1994) Paraniite-(Y), a new tungstate arsenate mineral from Alpine fissures. Schweizerische Mineralogische und Petrographische Mitteilungen, 74, 155-60.

Diamond LW (1992) Stability of $\mathrm{CO}_{2}$ clathrate hydrate $+\mathrm{CO}_{2}$ liquid $+\mathrm{CO}_{2}$ vapour+aqueous $\mathrm{KCl}-\mathrm{NaCl}$ solutions - experimental determination and application to salinity estimates of fluid inclusions. Geochimica et Cosmochimica Acta, 56, 273-80.

Diamond LW, Tarantola A (2015) Interpretation of fluid inclusions in quartz deformed by weak ductile shearing: reconstruction of differential stress magnitudes and predeformation fluid properties. Earth and Planetary Science Letters, 417, 107-19.

Dolejs D, Wagner T (2008) Thermodynamic modeling of nonideal mineral-fluid equilibria in the system Si-Al-Fe-Mg-Ca-Na$\mathrm{K}-\mathrm{H}-\mathrm{O}-\mathrm{Cl}$ at elevated temperatures and pressures: implications for hydrothermal mass transfer in granitic rocks. Geochimica et Cosmochimica Acta, 72, 526-53.

Dubessy J, Geisler D, Kosztolanyi C, Vernet M (1983) The determination of sulfate in fluid inclusions using the mole Raman microprobe - application to a Keuper halite and geochemical consequences. Geochimica et Cosmochimica Acta, 47, 1-10.

Dubessy J, Poty B, Ramboz C (1989) Advances in C-O-H-N-S fluid geochemistry based on micro-Raman spectroscopic analysis of fluid inclusions. European Journal of Mineralogy, 1, 517-34.

Evans KA, Powell R, Holland TJB (2010) Internally consistent data for sulphur-bearing phases and application to the construction of pseudosections for mafic greenschist facies rocks in $\mathrm{Na}_{2} \mathrm{O}-\mathrm{CaO}-\mathrm{K}_{2} \mathrm{O}-\mathrm{FeO}-\mathrm{MgO}-\mathrm{Al}_{2} \mathrm{O}_{3}-\mathrm{SiO}_{2}-\mathrm{CO}_{2}-\mathrm{O}-\mathrm{S}$ $\mathrm{H}_{2} \mathrm{O}$. Journal of Metamorphic Geology, 28, 667-87.

Ferry JM (1981) Petrology of graphitic sulfide-rich schists from south-central Maine - an example of desulfidation during prograde regional metamorphism. American Mineralogist, 66, 908-31. 
Ferry JM (1994) A historical review of metamorphic fluid-flow. Journal of Geophysical Research, B99, 15487-98.

Ferry JM, Dipple GM (1991) Fluid flow, mineral reactions, and metasomatism. Geology, 19, 211-4.

Fournier RO, Truesdell AH (1973) An empirical Na-K-Ca geothermometer for natural waters. Geochimica et Cosmochimica Acta, 37, 1255-75.

Frey M, Ferreiro Mählmann R (1999) Alpine metamorphism of the Central Alps. Schweizerische Mineralogische und Petrographische Mitteilungen, 79, 135-54.

Frey M, Bucher K, Frank E, Mullis J (1980) Alpine metamorphism along the geotraverse Basel-Chiasso: a review. Eclogae Geologicae Helvetiae, 73, 527-46.

Frezzotti ML, Tecce F, Casagli A (2012) Raman spectroscopy for fluid inclusion analysis. Journal of Geochemical Exploration, 112, $1-20$.

Frisch W (1979) Tectonic progradation and plate tectonic evolution of the Alps. Tectonophysics, 60, 121-39.

Fusswinkel T, Wagner T, Wälle M, Wenzel T, Heinrich CA, Markl G (2013) Fluid mixing forms basement-hosted Pb-Zn deposits: insight from metal and halogen geochemistry of individual fluid inclusions. Geology, 41, 679-82.

Fyfe WS, Price NJ, Thompson AB (1987) Fluids in the Earth's Crust. Elsevier, Amsterdam.

Giggenbach WF (1988) Geothermal solute equilibria - derivation of Na-K-Mg-Ca geoindicators. Geochimica et Cosmochimica Acta, 52, 2749-65.

Glotzbach C, Reinecker J, Danisik M, Rahn M, Frisch W, Spiegel C (2010) Thermal history of the central Gotthard and Aar massifs, European Alps: evidence for steady state, long-term exhumation. Journal of Geophysical Research-Earth Surface, 115, F03017.

Goldfarb RJ, Groves DI (2015) Orogenic gold: common or evolving fluid and metal sources. Lithos, 233, 2-26.

Goldstein RH, Reynolds TJ (1994) Systematics of fluid inclusions in diagenetic minerals. Society of Sedimentary Geology Short Course Series, 31, 1-199.

Groves DI, Goldfarb RJ, Robert F, Hart CJR (2003) Gold deposits in metamorphic belts: overview of current understanding, outstanding problems, future research, and exploration significance. Economic Geology, 98, 1-29.

Grujic D, Mancktelow NS (1996) Structure of the northern Maggia and Lebendun nappes, central Alps, Switzerland. Eclogae Geologicae Helvetiae, 89, 461-504.

Guillong M, Heinrich CA (2007) Sensitivity enhancement in laser ablation ICP-MS using small amounts of hydrogen in the carrier gas. Journal of Analytical Atomic Spectrometry, 22, 1488-94.

Guillong M, Meier DL, Allan MM, Heinrich CA, Yardley BWD (2008) SILLS: a Matlab-based program for the data reduction of laser ablation ICP-MS data of homogeneous materials and inclusions. Mineralogical Association of Canada Short Course Series, 40, 328-33.

Günther D, Frischknecht R, Heinrich CA, Kahlert HJ (1997) Capabilities of an argon fluoride $193 \mathrm{~nm}$ excimer laser for laser ablation inductively coupled plasma mass spectrometry microanalysis of geological materials. Journal of Analytical Atomic Spectrometry, 12, 939-44.

Günther D, Audétat A, Frischknecht R, Heinrich CA (1998) Quantitative analysis of major, minor and trace elements in fluid inclusions using laser ablation-inductively coupled plasma mass spectrometry. Journal of Analytical Atomic Spectrometry, 13, 263-70.

Hall AJ (1986) Pyrite-pyrrhotine redox reactions in nature. Mineralogical Magazine, 50, 223-9.
Handy MR, Schmid SM, Bousquet R, Kissling E, Bernoulli D (2010) Reconciling plate-tectonic reconstruction of Alpine Tethys with the geological-geophysical record of spreading and subduction in the Alps. Earth Science Reviews, 102, 121-58.

Heijlen W, Banks DA, Muchez P, Stensgard BM, Yardley BWD (2008) The nature of mineralizing fluids of the Kipushi $\mathrm{Zn}-\mathrm{Cu}$ deposit, Katanga, Democratic Repubic of Congo: quantitative fluid inclusion analysis using laser ablation ICP-MS and bulk crush-leach methods. Economic Geology, 103, 1459-82.

Heinrich CA (1986) Eclogite facies regional metamorphism of hydrous mafic rocks in the Central Alpine Adula nappe. Journal of Petrology, 27, 123-54.

Heinrich CA, Ryan CG, Mernagh TP, Eadington PJ (1992) Segregation of ore metals between magmatic brine and vapor: a fluid inclusion study using PIXE microanalysis. Economic Geology, 87, 1566-83.

Heinrich CA, Bain JHC, Fardy JJ, Waring CL (1993) Br/Cl geochemistry of hydrothermal brines associated with Proterozoic metasediment-hosted copper mineralization at Mount Isa, northern Australia. Geochimica et Cosmochimica Acta, 57, 2991-3000.

Heinrich CA, Pettke T, Halter WE, Aigner-Torres M, Audetat A, Günther D, Hattendorf B, Bleiner D, Guillong M, Horn I (2003) Quantitative multi-element analysis of minerals, fluid and melt inclusions by laser-ablation inductively-coupled-plasma massspectrometry. Geochimica et Cosmochimica Acta, 67, 3473-97.

Helgeson HC, Kirkham DH, Flowers GC (1981) Theoretical prediction of the thermodynamic behavior of aqueous electrolytes at high pressures and temperatures. IV. Calculation of activity coefficients, osmotic coefficients, and apparent molal and standard and relative partial molal properties to $600^{\circ} \mathrm{C}$ and 5 KB. American Journal of Science, 281, 1249-516.

Hofmann BA, Knill MD (1996) Geochemistry and genesis of the Lengenbach $\mathrm{Pb}-\mathrm{Zn}$-As-Tl-Ba-mineralization, Binn valley, Switzerland. Mineralium Deposita, 31, 319-39.

Holland T, Powell R (1996) Thermodynamics of order-disorder in minerals. II. Symmetric formalism applied to solid solutions. American Mineralogist, 81, 1425-37.

Holland TJB, Powell R (1998) An internally consistent thermodynamic data set for phases of petrological interest. Journal of Metamorphic Geology, 16, 309-43.

Holland T, Powell R (2003) Activity-composition relations for phases in petrological calculations: an asymmetric multicomponent formulation. Contributions to Mineralogy and Petrology, 145, 492-501.

Holland T, Baker J, Powell R (1998) Mixing properties and activity-composition relationships of chlorites in the system $\mathrm{MgO}-\mathrm{FeO}-\mathrm{Al}_{2} \mathrm{O}_{3}-\mathrm{SiO}_{2}-\mathrm{H}_{2} \mathrm{O}$. European Journal of Mineralogy, 10, 395-406.

Hollister LS, Burrus RC (1976) Phase equilibria in fluid inclusions from the Khtada Lake metamorphic complex. Geochimica et Cosmochimica Acta, 40, 163-75.

Hsü KJ (1991) Exhumation of high-pressure metamorphic rocks. Geology, 19, 107-10.

Hunziker JC, Desmons J, Martinotti G (1989) Alpine thermal evolution of the Western Alps: a review. Memoir Societa Geologia Italia, 29, 43-56.

Hurford AJ (1986) Cooling and uplift patterns in the Lepontine Alps South Central Switzerland and an age of vertical movement of the Insubric fault line. Contributions to Mineralogy and Petrology, 92, 413-27.

Indergand-Helfenstein P (2005) Historische Kristallfunde im Kanton Uri. Historischer Verein Uri Historisches Neujabrsblatt Neue Folge, 60, 57-79. 
Janots E, Engi M, Rubatto D, Berger A, Gregory C, Rahn M (2009) Metamorphic rates in collisional orogeny from in situ allanite and monazite dating. Geology, 37, 11-4.

Janots E, Berger A, Gnos E, Whitehouse M, Lewin E, Pettke T (2012) Constraints on fluid evolution during metamorphism from $\mathrm{U}-\mathrm{Th}-\mathrm{Pb}$ systematics in Alpine hydrothermal monazite. Chemical Geology, 326, 61-71.

Johnson WM, Maxwell JA (1981) Rock and Mineral Analysis. 2nd edn. Wiley, New York.

Johnson JW, Oelkers EH, Helgeson HC (1992) SUPCRT92: a software package for calculating the standard molal thermodynamic properties of minerals, gases, aqueous species, and reactions from 1 to 5000 bar and 0 to $1000^{\circ} \mathrm{C}$. Computers \& Geosciences, 18, 899-947.

Karpov IK, Chudnenko KV, Kulik DA (1997) Modeling chemical mass transfer in geochemical processes: thermodynamic relations, conditions of equilibria, and numerical algorithms. American Journal of Science, 297, 767-806.

Kendrick MA, Phillips D, Wallace M, Miller JML (2011) Halogens and noble gases in sedimentary formation waters and $\mathrm{Zn}-\mathrm{Pb}$ deposits: a case study from the Lennard Shelf, Australia. Applied Geochemistry, 26, 2089-100.

Kharaka YK, Mariner RH (1989) Chemical geothermometers and their application to formation waters from sedimentary basins. In: Thermal History of Sedimentary Basins (eds Naeser ND, McCulloh TH), pp. 99-117. Springer, New York.

Kharaka YK, Lico MS, Law LM (1982) Chemical geothermometers applied to formation waters, Gulf-of-Mexico and California basins. American Association of Petroleum Geologists Bulletin, 66, 588 .

Kulik DA, Wagner T, Dmytrieva SV, Kosakowski G, Hingerl FF, Chudnenko KV, Berner UR (2013) GEM-Selektor geochemical modeling package: revised algorithm and GEMS3K numerical kernel for coupled simulation codes. Computational Geosciences, 17, 1-24.

Manning CE (1998) Fluid composition at the blueschist eclogite transition in the model system $\mathrm{Na}_{2} \mathrm{O}-\mathrm{MgO}-\mathrm{Al}_{2} \mathrm{O}_{3}-$ $\mathrm{SiO}_{2}-\mathrm{H}_{2} \mathrm{O}-\mathrm{HCl}$. Schweizerische Mineralogische und Petrographische Mitteilungen, 78, 225-42.

Manning CE (2006) Mobilizing aluminum in crustal and mantle fluids. Journal of Geochemical Exploration, 89, 251-3.

Manning CA (2007) Solubility of corundum plus kyanite in $\mathrm{H}_{2} \mathrm{O}$ at $700^{\circ} \mathrm{C}$ and $10 \mathrm{kbar}$ : evidence for $\mathrm{Al}-\mathrm{Si}$ complexing at high pressure and temperature. Geofluids, 7, 258-69.

Marquer D, Burkhard M (1992) Fluid circulation, progressive deformation and mass-transfer in the upper crust: the example of basement-cover relationships in the External Crystalline Massifs, Switzerland. Journal of Structural Geology, 14, 1047-57.

Marsala A, Wagner T, Wälle M (2013) Late-metamorphic veins record deep ingression of meteoric water: a LA-ICPMS fluid inclusion study from the fold-and-thrust belt of the Rhenish Massif, Germany. Chemical Geology, 351, 134-53.

McCaffrey MA, Lazar B, Holland HD (1987) The evaporation path of seawater and the coprecipitation of $\mathrm{Br}^{-}$and $\mathrm{K}^{+}$with halite. Journal of Sedimentary Petrology, 57, 928-37.

McCaig AM, Tritlla J, Banks DA (2000) Fluid mixing and recycling during Pyrenean thrusting: evidence from fluid inclusion halogen ratios. Geochimica et Cosmochimica Acta, 64, 3395-412.

Meere PA, Banks DA (1997) Upper crustal fluid migration: an example from the Variscides of SW Ireland. Journal of the Geological Society London, 154, 975-85.

Menzies CD, Teagle DAH, Craw D, Cox SC, Boyce AJ, Barrie $\mathrm{CD}$, Roberts S (2014) Incursion of meteoric waters into the ductile regime in an active orogen. Earth and Planetary Science Letters, 399, 1-13.

Mercolli I, Schenker F, Stalder HA (1984) Geochemie der Veränderungen von Granit durch hydrothermale Lösungen (Zentr. Aaregranit). Schweizerische Mineralogische und Petrographische Mitteilungen, 64, 67-88.

Miron GD, Wagner T, Wälle M, Heinrich CA (2013) Major and trace-element composition and pressure-temperature evolution of rock-buffered fluids in low-grade accretionary-wedge metasediments, Central Alps. Contributions to Mineralogy and Petrology, 165, 981-1008.

Mohr DW, Newton RC (1983) Kyanite-staurolite metamorphism in sulfidic schists of the Anakeesta Formation, Great Smoky Mountains, North-Carolina. American Journal of Science, 283, 97-134.

Mullis J (1975) Growth conditions of quartz crystals from Val d'Illiez (Valais, Switzerland). Schweizerische Mineralogische und Petrographische Mitteilungen, 55, 419-29.

Mullis J (1987) Fluid inclusion studies during very low-grade metamorphism. In: Low Temperature Metamorphism (ed Frey M), pp. 162-99. Blackwell, Glasgow.

Mullis J (1988) Rapid subsidence and upthrusting in the Northern Apennines, deduced by fluid inclusion studies in quartz crystals from Porretta Terme. Schweizerische Mineralogische und Petrographische Mitteilungen, 88, 157-70.

Mullis J (1996) P-T-t path of quartz formation in extensional veins of the Central Alps. Schweizerische Mineralogische und Petrographische Mitteilungen, 76, 159-64.

Mullis J, Dubessy J, Poty B, O’Neil J (1994) Fluid regimes during late stages of a continental collision - physical, chemical, and stable-isotope measurements of fluid inclusions in fissure quartz from a geotraverse through the Central Alps, Switzerland. Geochimica et Cosmochimica Acta, 58, 2239-67.

Mullis J, Vennemann T, O'Neil JR (2001) Deep percolating meteoric waters in the Central Alps. Journal of Conference Abstracts, 6, 279.

Nieva D, Nieva R (1987) Developments in geothermal energy in Mexico - part twelve. A cationic geothermometer for prospecting of geothermal resources. Heat Recovery Systems and CHP, 7, 243-58.

Niggli E (1970) Alpine Metamorphose und alpine Gebirgsbildung. Fortschritte der Mineralogie, 47, 16-26.

Niggli E, Niggli KR (1965) Karten der Verbreitung einiger Mineralien der alpidischen Metamorphose in den Schweizer Alpen (Stilpnomelan, Alkali-Amphibol, Chloritoid, Staurolith, Disthen, Sillimanit). Schweizerische Mineralogische und Petrographische Mitteilungen, 58, 335-68.

Norris RJ, Henley RW (1976) Dewatering of a metamorphic pile. Geology, 80, 333-6.

Oberhänsli R, Goffé B, Bousquet R (1995) Record of a HP-LT metamorphic evolution in the Valais zone: geodynamic implications. Bolletino del Museo Regionale di Scienze Naturali, $13,221-40$.

Oliver NHS (1996) Review and classification of structural controls on fluid flow during regionel metamorphism. Journal of Metamorphic Geology, 14, 477-92.

Oliver NHS, Bons PD (2001) Mechanisms of fluid flow and fluidrock interaction in fossil metamorphic hydrothermal systems inferred from vein-wallrock patterns, geometry and microstructure. Geofluids, 1, 137-62.

Pfiffner OA, Ellis S, Beaumont C (2000) Collision tectonics in the Swiss Alps: insight from geodynamic modeling. Tectonics, 19, 1065-94. 
Phillips GN, Powell R (1993) Link between gold provinces. Economic Geology, 88, 1084-98.

Phillips GN, Powell R (2010) Formation of gold deposits: a metamorphic devolatilization model. Journal of Metamorphic Geology, 28, 689-718.

Poty B, Stalder HA, Weisbrod AM (1974) Fluid inclusion studies in quartz from fissures of Western and Central Alps. Schweizerische Mineralogische und Petrographische Mitteilungen, $\mathbf{5 4}, 717-52$.

Powell R, Holland T (1993) On the formulation of simple mixing models for complex phases. American Mineralogist, 78, 1174-80.

Powell R, Holland T (1999) Relating formulations of the thermodynamics of mineral solid solutions: activity modeling of pyroxenes, amphiboles, and micas. American Mineralogist, 84, $1-14$.

Powell R, Will TM, Phillips GN (1991) Metamorphism in Archean greenstone belts - calculated fluid compositions and implications for gold mineralization. Journal of Metamorphic Geology, 9, 141-50.

Purdy JW, Stalder HA (1973) K-Ar ages of fissure minerals from the Swiss Alps. Schweizerische Mineralogische und Petrographische Mitteilungen, 53, 79-98.

Ragnarsdottir KV, Walther JV (1985) Experimental determination of corundum solubilities in pure water between $400-700^{\circ} \mathrm{C}$ and 1-3 kbar. Geochimica et Cosmochimica Acta, 49, 2109-15.

Rauchenstein-Martinek K, Wagner T, Wälle M, Heinrich CA (2014) Gold concentrations in metamorphic fluids: a LAICPMS fluid inclusion study from the Alpine orogenic belt. Chemical Geology, 385, 70-83.

Ridley JR (1993) The relations between mean rock stress and fluid flow in the crust: with reference to vein-and lode-style gold deposits. Ore Geology Reviews, 8, 23-37.

Ridley JR, Diamond LW (2000) Fluid chemistry of orogenic lodegold deposits and implications for genetic models. Reviews in Economic Geology, 13, 141-62.

Rosenberg JL, Spry PG, Jacobson CE, Vokes FM (2000) The effects of sulfidation and oxidation during metamorphism on compositionally varied rocks adjacent to the Bleikvassli $\mathrm{Zn}-\mathrm{Pb}$ $(\mathrm{Cu})$ deposit, Nordland, Norway. Mineralium Deposita, 35, 714-26.

Rubatto D, Hermann J, Berger A, Engi M (2009) Protracted fluid-induced melting during Barrovian metamorphism in the Central Alps. Contributions to Mineralogy and Petrology, 158, 703-22.

Rudnick RL, Gao S (2004) Composition of the continental crust. Treatise on Geochemistry, 3, 1-64.

Salvi S, Pokrovski GS, Schott J (1998) Experimental investigation of aluminum-silica aqueous complexing at $300^{\circ} \mathrm{C}$. Chemical Geology, 151, 51-67.

Schlunegger F, Willett S (1999) Spatial and temporal variations in exhumation in the Central Swiss Alps and implications for exhumation mechanisms. Geological Society Special Publications, $154,157-79$.

Schmid SM, Pfiffner OA, Froitzheim N, Schönborn G, Kissling E (1996) Geophysical-geological transect and tectonic evolution of the Swiss-Italian Alps. Tectonics, 15, 1036-64.

Schmid SM, Fügenschuh B, Kissling E, Schuster R (2004) Tectonic map and overall architecture of the Alpine orogen. Eclogae Geologicae Helvetiae, 97, 93-117.

Seo JH, Guillong M, Aerts M, Zajacz Z, Heinrich CA (2011) Microanalysis of $\mathrm{S}, \mathrm{Cl}$, and $\mathrm{Br}$ in fluid inclusions by LA-ICPMS. Chemical Geology, 284, 35-44.

Sharp ZD, Masson H, Lucchini R (2005) Stable isotope geochemistry and formation mechanisms of quartz veins.
Extreme paleoaltitudes of the Central Alps in the Neogene. American Journal of Science, 305, 187-219.

Shock EL, Helgeson HC (1988) Calculation of the thermodynamic and transport properties of aqueous species at high pressures and temperatures: correlation algorithms for ionic species and equation of state predictions to $5 \mathrm{~kb}$ and $1000^{\circ} \mathrm{C}$. Geochimica et Cosmochimica Acta, 52, 2009-36.

Shock EL, Helgeson HC, Sverjensky DA (1989) Calculation of the thermodynamic and transport properties of aqueous species at high pressures and temperatures: standard partial molal properties of inorganic neutral species. Geochimica et Cosmochimica Acta, 53, 2157-83.

Shock EL, Sassani DC, Willis M, Sverjensky DA (1997) Inorganic species in geological fluids: correlations among standard molal thermodynamic properties of aqueous ions and hydroxide complexes. Geochimica et Cosmochimica Acta, 61, 907-50.

Spycher N, Peiffer L, Sonnenthal EL, Saldi G, Reed MH, Kennedy BM (2014) Integrated multicomponent solute geothermometry. Geothermics, 51, 113-23.

Stalder HA (1964) Petrographische und mineralogische Untersuchungen im Grimselgebiet. Schweizerische Mineralogische und Petrographische Mitteilungen, 44, 187-398.

Stalder HA (1986) Beschreibung der geschützten Mineralkluft Gerstenegg, Grimsel, Bern. Mitteilungen der Naturforschenden Gesellschaft Bern, 43, 41-60.

Stalder HA, De Quervain F, Niggli P, Graeser S (1973) Die Mineralfunde der Schweiz. Wepf Publisher, Basel, 433 pp.

Stober I, Bucher K (1999) Origin of salinity of deep groundwater in crystalline rocks. Terra Nova, 11, 181-5.

Stoffell B, Appold MS, Wilkinson JJ, McClean NA, Jeffries TE (2008) Geochemistry and evolution of Mississippi Valley-Type mineralizing brines from the Tri-State and northern Arkansas districts determined by LA-ICP-MS microanalysis of fluid inclusions. Economic Geology, 103, 1411-35.

Suleimenov OM, Seward TM (2000) Spectrophotometric measurements of metal complex formation at high temperatures: the stability of $\mathrm{Mn}(\mathrm{II})$ chloride species. Chemical Geology, 167, 177-92.

Sverjensky DA, Shock EL, Helgeson HC (1997) Prediction of the thermodynamic properties of aqueous metal complexes to $1000^{\circ} \mathrm{C}$ and $5 \mathrm{~kb}$. Geochimica et Cosmochimica Acta, 61, 1359412 .

Tagirov B, Schott J (2001) Aluminum speciation in crustal fluids revisited. Geochimica et Cosmochimica Acta, 65, 3965-92.

Tagirov B, Zotov AV, Akinfiev NN (1997) Experimental study of dissociation of $\mathrm{HCl}$ from 350 to $500^{\circ} \mathrm{C}$ and from 500 to 2500 bars. Thermodynamic properties of $\mathrm{HCl}^{0}(\mathrm{aq})$. Geochimica et Cosmochimica Acta, 61, 4267-80.

Tagirov B, Schott J, Harrichourry JC, Salvi S (2002a) Experimental study of aluminum speciation in fluoride-rich supercritical fluids. Geochimica et Cosmochimica Acta, 66, 201324.

Tagirov B, Schott J, Harrichoury JC (2002b) Experimental study of aluminum-fluoride complexation in near-neutral and alkaline solutions to $300^{\circ} \mathrm{C}$. Chemical Geology, 184, 301-10.

Tagirov B, Schott J, Harrichoury JC, Escalier J (2004) Experimental study of the stability of aluminate-borate complexes in hydrothermal solutions. Geochimica et Cosmochimica Acta, 68, 1333-45.

Tarantola A, Mullis J, Vennemann T, Dubessy J, de Capitani C (2007) Oxidation of methane at the $\mathrm{CH}_{4} / \mathrm{H}_{2} \mathrm{O}-\left(\mathrm{CO}_{2}\right)$ transition zone in the external part of the Central Alps, Switzerland: evidence from stable isotope investigations. Chemical Geology, 237, 329-57. 
Tarantola A, Mullis J, Guillaume D, Dubessy J, de Capitani C, Abdelmoula M (2009) Oxidation of $\mathrm{CH}_{4}$ to $\mathrm{CO}_{2}$ and $\mathrm{H}_{2} \mathrm{O}$ by chloritization of detrital biotite at $270 \pm 5^{\circ} \mathrm{C}$ in the external part of the Central Alps, Switzerland. Lithos, 112, 497-510.

Templeton AS, Chamberlain CP, Koons PO, Craw D (1999) Stable isotopic evidence for mixing between metamorphic fluids and surface-derived waters during recent uplift of the Southern Alps, New Zealand. Earth and Planetary Science Letters, 154, 73-92.

Thébaud N, Philippot P, Rey P, Cauzid J (2006) Composition and origin of fluids associated with lode gold deposits in a Mesoarchean greenstone belt (Warrawoona Syncline, Pilbara Craton, Western Australia) using synchrotron radiation $\mathrm{X}$-ray fluorescence. Contributions to Mineralogy and Petrology, 152, 485-503.

Thiery R, van den Kerkhof AM, Dubessy J (1994) vX properties of $\mathrm{CH}_{4}-\mathrm{CO}_{2}$ and $\mathrm{CO}_{2}-\mathrm{N}_{2}$ fluid inclusions; modelling for $\mathrm{T}<31^{\circ} \mathrm{C}$ and $\mathrm{P}<400$ bars. European Journal of Mineralogy, 6, 753-71.

Tian Y, Etschmann B, Mei Y, Grundler PV, Testemale D, Hazeman JL, Elliott P, Ngothai Y, Brugger J (2014) Speciation and thermodynamic properties of manganese(II) chloride complexes in hydrothermal fluids: in situ XAS study. Geochimica et Cosmochimica Acta, 129, 77-95.

Todd CS, Engi M (1997) Metamorphic field gradients in the Central Alps. Journal of Metamorphic Geology, 15, 513-30.

Tomkins AG (2007) Three mechanisms of ore re-mobilisation during amphibolite facies metamorphism at the Montauban $\mathrm{Zn}$ $\mathrm{Pb}-\mathrm{Au}-\mathrm{Ag}$ deposit. Mineralium Deposita, 42, 627-37.

Tomkins AG (2010) Windows of metamorphic sulfur liberation in the crust: implications for gold deposit genesis. Geochimica et Cosmochimica Acta, 74, 3246-59.

Touret J (1982) An empirical phase diagram for a part of the $\mathrm{N}_{2}$ $\mathrm{CO}_{2}$ system at low temperature. Chemical Geology, 37, 49-58.

Touret JLR (2001) Fluids in metamorphic rocks. Lithos, 55, 1-25.

Tricart P (1984) From passive margin to continental collision: a tectonic scenario for the Western Alps. American Journal of Science, 284, 97-120.

Trommsdorff V (1966) Progressive Metamorphose kieseliger Karbonatgesteine in den Zentralalpen zwischen Bernina und Simplon. Schweizerische Mineralogische und Petrographische Mitteilungen, 46, 431-60.

Trümpy R (1960) Paleotectonic evolution of the Central and Western Alps. Geological Society of America Bulletin, 71, 843-928.

Verlaguet A, Brunet F, Goffe B, Murphy WM (2006) Experimental study and modeling of fluid reaction paths in the quartzkyanite \pm muscovite-water system at $0.7 \mathrm{GPa}$ in the $350-550^{\circ} \mathrm{C}$ range: implications for $\mathrm{Al}$ selective transfer during metamorphism. Geochimica et Cosmochimica Acta, 70, 1772-88.

Vialon P (1990) Deep Alpine structures and geodynamic evolution: an introduction and outline of a new interpretation. Memoirs Societe Geologique France, 156, 7-14.

Wagner T, Kulik DA, Hingerl FF, Dmytrieva SV (2012) GEMSelektor geochemical modeling package: TSolMod library and data interface for multicomponent phase models. Canadian Mineralogist, 50, 1173-95.

Walther JV (1997) Determination of activity coefficients of neutral species in supercritical $\mathrm{H}_{2} \mathrm{O}$ solutions. Geochimica et Cosmochimica Acta, 61, 3311-8.

Walther JV (2001) Experimental determination and analysis of the solubility of corundum in 0.1 and $0.5 \mathrm{~m} \mathrm{NaCl}$ solutions between 400 and $600^{\circ} \mathrm{C}$ from 0.5 to $2.0 \mathrm{kbar}$. Geochimica et Cosmochimica Acta, 65, 2843-51.

Wei CJ, Powell R, Zhang LF (2003) Eclogites from the south Tianshan, NW China: petrological characteristics and calculated mineral equilibria in the $\mathrm{Na}_{2} \mathrm{O}-\mathrm{CaO}-\mathrm{FeO}-\mathrm{MgO}-\mathrm{Al}_{2} \mathrm{O}_{3}-\mathrm{SiO}_{2}$ $\mathrm{H}_{2} \mathrm{O}$ system. Journal of Metamorphic Geology, 21, 163-79.

Weisenberger T, Bucher K (2010) Zeolites in fissures of granites and gneisses of the Central Alps. Journal of Metamorphic Geology, 28, 825-47.

Wenk E (1970) Zur Regionalmetamorphose und Ultrametamorphose im Lepontin. Fortschritte der Mineralogie, 47, 34-51.

Wickham SM, Taylor HP (1985) Stable isotopic evidence for large-scale seawater infiltration in a regional metamorphic terrane; the Trois Seigneurs Massif, Pyrenees, France. Contributions to Mineralogy and Petrology, 91, 122-37.

Wiederkehr M, Sudo M, Bousquet R, Berger A, Schmid SM (2009) Alpine orogenic evolution from subduction to collisional thermal overprint: the ${ }^{40} \mathrm{Ar} /{ }^{39} \mathrm{Ar}$ age constraints from the Valaisan Ocean, central Alps. Tectonics, 28, TC6009.

Wiederkehr M, Bousquet R, Ziemann MA, Berger A, Schmid SM (2011) 3-D assessment of peak-metamorphic conditions by Raman spectroscopy of carbonaceous material: an example from the margin of the Lepontine dome (Swiss Central Alps). International Journal of Earth Sciences, 100, 1029-63.

Wilson AD (1960) The micro-determination of ferrous iron in silicate minerals by a volumetric and a colorimetric method. Analyst, 85, 823-7.

Wolfram O, Krupp RE (1996) Hydrothermal solubility of rhodochrosite, $\mathrm{Mn}(\mathrm{II})$ speciation, and equilibrium constants. Geochimica et Cosmochimica Acta, 60, 3983-94.

Wood SA, Samson IM (1998) Solubility of ore minerals and complexation of ore minerals in hydrothermal solutions. Reviews in Economic Geology, 10, 33-80.

Wülser PA, Brugger J, Foden J, Pfeifer HR (2011) The sandstonehosted Beverley uranium Deposit, Lake Frome Basin, South Australia: mineralogy, geochemistry, and a time-constrained model for its genesis. Economic Geology, 106, 835-67.

Yardley BWD (1983) Quartz veins and devolatilization during metamorphism. Journal of the Geological Society London, 140, 657-63.

Yardley BWD (2005) Metal concentrations in crustal fluids and their relationship to ore formation. Economic Geology, 100, 613-32.

Yardley BWD (2013) The chemical composition of metasomatic fluids in the crust. In: Metasomatism and the Chemical Transformation of Rocks (eds Harlov DE, Austrheim H), pp. 17-51. Springer, Heidelberg.

Yardley BWD, Banks DA, Bottrell SH, Diamond LW (1993) Postmetamorphic gold quartz veins from NW Italy - the composition and origin of the ore Fluid. Mineralogical Magazine, 57, 407-22.

Zhang Y, Frantz JD (1987) Determination of homogenization temperature and densities of supercritical fluid in the system $\mathrm{NaCl}-\mathrm{KCl}-\mathrm{CaCl}_{2}-\mathrm{H}_{2} \mathrm{O}$ using synthetic fluid inclusions. Chemical Geology, 64, 335-50.

\section{SUPPORTING INFORMATION}

Additional Supporting Information may be found online in the supporting information tab for this article:

Data S1. Fluid inclusion data (Thusis, Gauli, Gerstenegg, Tiefengletscher, Vals, Bedretto, Cavagnoli, and Faido). 


\title{
GEOFLUIDS
}

\author{
Volume 16, Number 5, December 2016 \\ ISSN 1468-8115
}

\section{CONTENTS}

801 Injection-induced seismicity in Carbon and Emery Counties, central Utah M.R.M. Brown and M. Liu

813 Large-scale chemical stratification of fluids in the crust: hydraulic and chemical data from the geothermal research site Urach, Germany K. Bucher and I. Stober

826 The October 2008 Nový Kostel earthquake swarm and its gas geochemical precursor F.H. Weinlich, R. Gaždová, M. Teschner and J. Poggenburg

841 Quantitative analysis of $\mathrm{COH}$ fluids synthesized at HP-HT conditions: an optimized methodology to measure volatiles in experimental capsules

C. Tiraboschi, S. Tumiati, S. Recchia, F. Miozzi and S. Poli

856 Origin of dolomites in the Cambrian (upper 3rd-Furongian) formation, south-eastern Sichuan Basin, China M.C. Hou, W.J. Jiang, F.C. Xing, S.L. Xu, X.C. Liu and C. Xiao

877 Chemical evolution of metamorphic fluids in the Central Alps, Switzerland: insight from LA-ICPMS analysis of fluid inclusions K. Rauchenstein-Martinek, T. Wagner, M. Wälle, C.A. Heinrich and T. Arlt

909 Organic-inorganic rock-fluid interactions in stylolitic micro-environments of carbonate rocks: a FIB-TEM study combined with a hydrogeochemical modelling approach H. -M. Schulz, R. Wirth and A. Schreiber

925 Linked thermal convection of the basement and basinal fluids in formation of the unconformity-related uranium deposits in the Athabasca Basin, Saskatchewan, Canada A.A. Pek and V.I. Malkovsky

941 The role of the stress regime on microseismicity induced by overpressure and cooling in geologic carbon storage V. Vilarrasa

954 Numerical model of pore-pressure diffusion associated with the initiation of the 2010-2011 Guy-Greenbrier, Arkansas earthquakes P.O. Ogwari and S.P. Horton

971 Exploring the potential linkages between oil-field brine reinjection, crystalline basement permeability, and triggered seismicity for the Dagger Draw Oil field, southeastern New Mexico, USA, using hydrologic modeling Y. Zhang, S.S. Edel, J. Pepin, M. Person, R. Broadhead, J.P. Ortiz, S.L. Bilek, P. Mozley and J.P. Evans

988 Fluid chemistry in the Solitaire and Dodo hydrothermal fields of the Central Indian Ridge

S. Kawagucci, J. Miyazaki, T. Noguchi, K. Okamura, T. Shibuya, T. Watsuii, M. Nishizawa, H. Watanabe, K. Okino, N. Takahata, Y. Sano, K. Nakamura, A. Shuto, M. Abe, Y. Takaki, T. Nunoura, M. Koonjul, M. Singh, G. Beedessee, M. Khishma, V. Bhoyroo, D. Bissessur, L.S. Kumar, D. Marie, K. Tamaki and K. Takai

1006 Direct inversion of Young's and Poisson impedances for fluid discrimination Z. Zong and $\mathrm{X}$. Yin

1017 Bleached mudstone, iron concretions, and calcite veins: a natural analogue for the effects of reducing $\mathrm{CO}_{2}$-bearing fluids on migration and mineralization of iron, sealing properties, and composition of mudstone cap rocks

X.R. Ming, L. Liu, M. Yu, H.G. Bai, L. Yu, X.L. Peng and T.H. Yang

1043 Dry $\mathrm{CO}_{2}-\mathrm{CO}$ fluid as an important potential deep Earth solvent A.G. Simakin, T.P. Salova, R.I. Gabitov and S.I. Isaenko 